\title{
Ontwerp van een arbeidsmarktscanner voor academici : een pilotstudie in de gezondheidswetenschappen naar de mogelijkheden om de arbeidsmarktpositie en loopbaan van afgestudeerden in kaart te brengen
}

Citation for published version (APA):

van Dam, J. W., Heijke, J. A. M., \& Ramaekers, G. W. M. (1989). Ontwerp van een arbeidsmarktscanner voor academici : een pilotstudie in de gezondheidswetenschappen naar de mogelijkheden om de arbeidsmarktpositie en loopbaan van afgestudeerden in kaart te brengen. Researchcentrum voor Onderwijs en Arbeidsmarkt, Faculteit der Economische Wetenschappen. ROA Reports No. 3 https://doi.org/10.26481/umarep.1989003

Document status and date:

Published: 01/01/1989

DOI:

10.26481/umarep.1989003

Document Version:

Publisher's PDF, also known as Version of record

Please check the document version of this publication:

- A submitted manuscript is the version of the article upon submission and before peer-review. There can be important differences between the submitted version and the official published version of record. People interested in the research are advised to contact the author for the final version of the publication, or visit the DOI to the publisher's website.

- The final author version and the galley proof are versions of the publication after peer review.

- The final published version features the final layout of the paper including the volume, issue and page numbers.

Link to publication

\footnotetext{
General rights rights.

- You may freely distribute the URL identifying the publication in the public portal. please follow below link for the End User Agreement:

www.umlib.nl/taverne-license

Take down policy

If you believe that this document breaches copyright please contact us at:

repository@maastrichtuniversity.nl

providing details and we will investigate your claim.
}

Copyright and moral rights for the publications made accessible in the public portal are retained by the authors and/or other copyright owners and it is a condition of accessing publications that users recognise and abide by the legal requirements associated with these

- Users may download and print one copy of any publication from the public portal for the purpose of private study or research.

- You may not further distribute the material or use it for any profit-making activity or commercial gain

If the publication is distributed under the terms of Article $25 \mathrm{fa}$ of the Dutch Copyright Act, indicated by the "Taverne" license above,

Download date: 26 Apr. 2023 
ONTWERP VAN EEN ARBEIDSMARKTSCANNER

VOOR ACADEMICI

Een pilotstudie in de gezondheidswetenschappen naar de mogelijkheden om de arbeidsmarktpositie en loopbanen van afgestudeerden in kaart te brengen

ROA-R-1989/3

J.W. van Dam

J.A.M. Heijke

G.W.M. Ramaekers

RESEARCHCENTRUM VOOR ONDERWIJS EN ARBEIDSMARKT

Faculteit der Economische Wetenschappen

Rijksuniversiteit Limburg

Maastricht, november 1989 
VERANTWOORDING

SAMENVATTING

1. INLEIDING 1

1.1. De probleemstelling van de pilotstudie 1

1.2. De indeling van dit raport 3

2. DE RELEVANTIE VAN INFORMATIE OVER ONDERWIJS EN ARBEIDSMARKT 5

2.1. Inleiding 5

2.2. Arbeidsmarktfricties en enkele oorzaken van discrepanties $\mathbf{5}$

2.3. Belanghebbenden bij informatie over de arbeidsmarkt voor 7 academici

2.4. Benodigde gegevens 10

2.5. Randvoorwaarden 12

3. OPLEIDING EN ARBEIDSMARKT VAN GEZONDHEIDSWETENSCHAPPERS 14

3.1. Inleiding 14

3.2. Ontwikkelingen in de gezondheidszorg in Nederland 15

3.3. Arbeidsmarkt en arbeidsplaatsen in de gezondheidszorg 18

3.4. Opleidingen voor gezondheidswetenschappers in Nederland 22

3.5. Data over gezondheidswetenschappers op de arbeidsmarkt 29

3.6. Conclusies 33

4. EVALUATIE VAN METHODEN VAN ENQUETERING VAN AFGESTUDEERDEN 35

4.1. Inleiding 35

4.2. Nederland 35

4.2.1. Organisatievormen 35

4.2.2. Doelstellingen 37

4.2.3. Het up-to-date houden 37

4.2.4. Representativiteit 38

4.2.5. Onderzoeksmethoden en wijze van verwerking 39

4.2.6. Onderzoeksvragen en -items 40

4.2.7. Definities en classificaties 41 
4.3. Buitenland: Groot-Brittannië en Ontario 43

4.3.1. Inleiding 43

4.3.2. First-destinations survey in Groot-Brittannië 44

4.3.3. Employment survey of graduates of Ontario 47 Universities

4.3.4. Vergelijking first-destination. surveys Groot- 49 Britannië en Ontario

4.4. Conclusies

52

5. STANDAARDVRAGENLIJSTEN VOOR DE AANBODZIJDE 55

5.1. Inleiding 55

5.2. De constructie van de vragenlijsten 56

5.2.1. Werkwijze 56

5.2.2. De inhoud en samenstelling van de vragenlijst 56

5.3. Het testen van de vragenlijst 59

5.3.1. Bijstellingen op grond van de evaluatieformulieren 59

5.3.2. Bijstellingen op grond van de ingevulde jaar- en 61 basiskaarten

6. AANZET TOT HET IN KAART BRENGEN VAN DE VRAAGZIJDE 62

6.1. Inleiding 62

6.2. De benodigde informatie over de vraagzijde 62

6.3. Beschikbare informatie over werkgevers en werknemers 64 in de gezondheidszorg

6.4. De te hanteren onderzoeksmethoden en de onderzoekspopulatie 65

6.5. De jaarlijkse vragenlijst voor werkgevers in de 69 gezondheidszorg

6.6. Het vooronderzoek onder werkgevers 70

6.7. Conclusies 73

7. ORGANISATORISCHE ASPECTEN VAN DE ARBEIDSMARKTSCANNER VOOR 75 ACADEMICI

7.1. Inleiding 75

7.2. Actualisering adressenbestand en verhoging respons 75

7.3. Voorziening op universitair niveau 78

7.4. Voorziening op landelijk niveau 82

7.5. Organisatie van het onderzoek onder werkgevers 83

7.6. Conclusies 84 
8. OUTPUT VAN DE ARBEIDSMARKTSCANNER VOOR ACADEMICI 86

8.1. Inleiding 86

8.2. Twee voorbeelden van standaardrapportages 87

8.3. Presentatie van de output 88

8.4. Conclusies 90

LITERATUUR $\quad 92$

Bijlage I : Basisvragenkaart, toelichting op de basisvragenkaart en introduktiebrief

Bijlage II : Jaarkaart, toelichting op de jaarkaart en introduktiebrief

Bijlage III: Evaluatieformulier voor het testen van de kaarten

Bijlage IV : Facultatieve items in de first-destinations surveys in Groot-Brittannië 


\section{VERANTWOORDING}

In de zomer van 1988 verleende het Directoraat-Generaal voor het Hoger Onderwijs van het Ministerie van Onderwijs en Wetenschappen aan het Researchcentrum voor Onderwijs en Arbeidsmarkt van de Rijksuniversiteit Limburg de opdracht om een pilotstudie te verrichten in de Faculteit der Gezondheidswetenschappen van de Rijksuniversiteit Limburg. Het betrof het ontwikkelen van een onderzoeksmethodiek waarmee op continue basis informatie wordt verkregen over de arbeidsmarktpositie van afgestudeerde academici. Deze informatie zou gedetailleerd moeten zijn en koppelbaar met andere databestanden. In dit rapport wordt verslag gedaan van de onderzoeksbevindingen.

Aan dit rapport hebben diverse personen bijgedragen. De projectleiding van het onderzoek was in handen van prof. dr. J.A.M. Heijke. De uitvoering ervan berustte voor een groot deel bij drs. J.W. van Dam die in het bijzonder de hoofdstukken 1 tot en met 6 samenstelde. Drs. G. Ramaekers schreef in het bijzonder paragraaf 2.3. en de hoofdstukken 7 en 8 en verzorgde de eindredactie van het rapport. Mevrouw $P$. van de Loo had een belangrijke bijdrage in het verzamelen van de informatie voor hoofdstuk 3 en het ontwikkelen van de vragenlijsten voor afgestudeerden.

Het onderzoek werd begeleid door de commissie 'Beroepsperspectieven Gezondheidswetenschappers' van de Faculteit der Gezondheidswetenschappen van de Rijksuniversiteit Limburg, bestaande uit de volgende personen:

- Dr. H. Adriaanse, voorzitter, portefeuillehouder externe betrekkingen in het bestuur van de Faculteit der Gezondheidswetenschappen;

- Dr. R. Janssen, medewerker Faculteit der Gezondheidswetenschappen, vakgroep Economie van de Gezondheidszorg;

- Drs. M.L. Schreurs, medewerkster vakgroep Onderwijsontwikkeling en Onderwijsresearch van de Faculteit der Gezondheidswetenschappen;

- Prof. dr. F.A. Vorst, emeritus-hoogleraar Faculteit der Gezondheidswetenschappen;

- Drs. M. te Wierik, Nederlandse Vereniging voor Gezondheidswetenschappen;

- Prof. dr. F. van Wijmen, Hoogleraar Gezondheidsrecht, Faculteit der Gezondheidswetenschappen;

- Prof. dr. W. Wijnen, Hoogleraar Onderwijsontwikkeling en -research, Faculteit der Geneeskunde. 


\section{SAMENVATTING}

Hoewel er veel kwalitatief en kwantitatief onderzoek wordt verricht naar de arbeidsmarktperspectieven van universitaire opleidingen en de waardering van afgestudeerden voor de door hen gevolgde opleiding, zijn de resultaten van dergelijke onderzoeken doorgaans niet of slecht met elkaar te vergelijken. Dat is jammer, want de behoefte aan vergelijkbare informatie over de aansluiting van het onderwijs op de arbeidsmarkt is de afgelopen jaren sterk toegenomen. Om daarin te kunnen voorzien is aan het Researchcentrum voor Onderwijs en Arbeidsmarkt opdracht verleend om een onderzoeksmethodiek te ontwikkelen waarmee een voor een universitaire opleiding relevant arbeidsmarktsegment zou kunnen worden 'gescanned'. In deze pilotstudie is gekozen voor de opleiding en de arbeidsmarkt voor gezondheidswetenschappers.

De arbeidsmarktinformatie die met behulp van de ontwikkelde scannner kan worden voortgebracht, zou voor verschillende groepen van belanghebbenden van nut kunnen zijn. Te denken valt aan studievoorlichters en beroepskeuzeadviseurs, planners en ontwikkelaars van (nieuwe) onderwijsvoorzieningen en -programma's, aanbieders van reeds bestaande curricula, personeelsfunctionarissen bij werkgevers, medewerkers van beroepsverenigingen en belangenorganisaties, arbeidsmarktonderzoekers en statistici.

De volgende informatie zou voor genoemde groepen van belang kunnen zijn:

- informatie over de kansen op werk na het verlaten van de opleiding, in het bijzonder in de beroepsdomeinen warop de desbetreffende opleidingen beogen aan te sluiten;

- informatie over het te verwerven inkomen, de arbeidsvoorwaarden en de carrièremogelijkheden in deze beroepsdomeinen;

- informatie over de doelmatigheid van de opleiding in relatie tot de eisen die de beroepsuitoefening stelt;

- informatie over de omvang en samenstelling van de toekomstige uitstroom uit de diverse opleidingen.

In dit onderzoek is nagegaan in hoeverre bovengenoemde gegevens aanwezig zijn voor de Faculteit der Gezondheidswetenschappen van de Rijksuniversiteit Limburg, haar afgestudeerden en het beroependomein waarop deze faculteit zich in het bijzonder richt. Daarbij is gebleken dat er weliswaar veel kwantitatieve informatie voorhanden is over de beroepensamenstelling van de gezondheidszorg, en dan met name voor de intramurale gezondheidszorg, doch 
tevens bleek dat weinig bekend is over de opleidingsstructuur van deze sector. Uitstroomgegevens van opleidingen voor gezondheidswetenschappen zijn zeer beperkt voorhanden. Het Centraal Bureau voor de Statistiek voegt de gegevens over het aantal gediplomeerden van enkele op elkaar gelijkende opleidingen bij elkaar, zodat deze niet zijn te herleiden tot afzonderlijke faculteiten. Van enkele faculteiten zijn de resultaten bekend van onderzoek dat is gedaan naar de eerste bestemming van de afgestudeerden. Ook deze onderzoeksresultaten zijn onderling moeilijk vergelijkbaar, onder meer vanwege de zeer globale categorisering van de antwoorden. Bovendien gaat het in alle gevallen om een incidentele bevraging. Processen als substitutie en verdringing zijn hierdoor niet waar te nemen.

De opleidingen voor gezondheidswetenschappers staan daarin overigens niet alleen. Uit een inventarisatie van Nederlandse en buitenlandse onderzoekingen onder afgestudeerden bleek dat er feitelijk nooit sprake is van loopbaanonderzoeken welke worden gekenmerkt door een longitudinale opzet.

De bruikbaarheid van onderzoeksresultaten wordt eveneens beperkt vanwege de grote diversiteit in de organisaties die onderzoek onder afgestudeerden verrichten, en vanwege hun zeer uiteenlopende motieven en werkwijzen. Hierdoor ontstaan onoverkomelijke verschillen in de wijze waarop onderzoeksresultaten worden gecategoriseerd en gepresenteerd.

In Groot-Brittannië en in de Canadese deelstaat Ontario is men er in geslaagd om het onderzoek onder de afgestudeerden van alle universiteiten en hogescholen gecoördineerd te doen verrichten. In Groot-Brittannië gebeurt dit op initiatief van de Association of Graduate Careers Advisory Services, een overkoepelend orgaan van de aan alle universiteiten verbonden Careers Advisory Services. De centrale overheid speelt bij dit onderzoek nauwelijks een rol. In Ontario ligt het initiatief voor de coördinatie echter bij de centrale overheid. Het onderzoek wordt verricht door één onderzoeksinstituut op kosten van de centrale overheid. De universiteiten en hogescholen dienen een adressenbestand van de afgestudeerden aan te leveren. De gekozen onderzoeksopzet, waarbij veel afhangt van de mate waarin adressenbestanden zijn geactualiseerd, leidt in beide landen tot kwaliteitsverschillen in de resultaten per universiteit. Tevens is in beide landen het onderzoek beperkt tot de aanbodzijde van de arbeidsmarkt, waardoor arbeidsmarktprognoses moeilijk zijn te maken. 
Om zo goed mogelijk tegemoet te komen aan de nadelen en beperkingen die in het voorgaande zijn gesignaleerd, is een drietal vragenlijsten ontwikkeld waarmee informatie over zowel de aanbodzijde van de arbeidsmarkt als de vraagzijde kan worden gegenereerd.

Voor de aanbodzijde zijn een zogeheten 'basiskaart' en een 'jaarkaart' ontwikkeld. De basiskaart wordt aan iedere afgestudeerde circa één jaar na het afstuderen toegezonden. Met deze kaart wordt beoogd een beeld te krijgen van de genoten opleiding en de eerste bestemming op de arbeidsmarkt. Vervolgens wordt ieder jaar de jaarkaart toegezonden. Hiermee wordt gevraagd naar eventueel aanvullende opleidingen, aspecten die het beroep betreffen en de daarin opgetreden veranderingen.

Voor de vraagzijde wordt één vragenlijst ontwikkeld waarmee enkele gegevens betreffende de omvang en samenstelling naar functie, opleiding en leeftijd van het werknemersbestand jaarlijks kunnen worden achterhaald. Daarbij ligt de nadruk op informatie over de hoger opgeleide werknemers. De vragenlijst zal meerjaarlijks worden aangevuld met een aantal extra vragen met betrekking tot het wervings- en selectiebeleid, het intern opleidingsbeleid en de verwachte personele ontwikkeling op middellange termijn. Op basis van de resultaten van het onderzoek onder afgestudeerden zal een klein doch zo representatief mogelijk panel van werkgevers worden samengesteld. De vragenlijst zal jaarlijks aan de hoofden van personeelszaken worden voorgelegd.

Voor het welslagen van de systematische peiling onder afgestudeerden vormt een actueel adressenbestand van oud-studenten een eerste vereiste. Bij het onderzoek kan gebruik worden gemaakt van het geactualiseerd adressenbestand van een magazine voor externe relaties (waaronder oud-studenten), een lidmaatschapsorganisatie van een universiteit, een beroeps- of studievereniging of een vereniging van afgestudeerden. Vooral een magazine kan de bereidheid van oud-studenten om adreswijzigingen door te geven en aan het onderzoek mee te werken vergroten.

Binnen een universiteit dient de systematische peiling onder afgestudeerden bij voorkeur beheersmatig onafhankelijk te worden georganiseerd als een facilitaire voorziening ten behoeve van de hele universiteit. Het scheppen van één voorziening biedt schaalvoordelen met betrekking tot de exploitatie van de verzamelde gegevens, garandeert dat het onderzoek binnen de universiteit gecoördineerd en op uniforme wijze plaatsvindt, maakt bundeling van 
professionele know-how mogelijk, en biedt één aanspreekpunt voor belanghebbenden. Ten behoeve van een dergelijke onderzoeksvoorziening kan een aparte onderzoeksorganisatie binnen een universiteit in het leven worden geroepen. Deze voorziening kan echter ook deel uitmaken van een organisatie met meer taken dan alleen het verrichten van systematisch onderzoek onder afgestudeerden. In het laatste geval voorkomt een beheersmatig onafhankelijke opzet van de onderzoeksvoorziening of uitbesteding aan een onderzoeksinstituut het gevaar dat een vermenging optreedt van onderzoek en beleid en dat het onderzoek ondergesneeuwd raakt tussen de andere taken van de desbetreffende organisatie. Bovendien is een beheersmatig onafhankelijke opzet bevorderlijk voor de eigen identiteit van de onderzoeksvoorziening.

Het is van groot belang dat het verzamelen en het verwerken van de gegevens over afgestudeerden binnen de afzonderlijke universiteiten op uniforme wijze plaatsvindt, met gebruikmaking van standaarddefinities en standaardclassificaties. Alleen dan kan de voortgebrachte informatie worden ingepast in een landelijk bestand van basisgegevens dat bruikbaar is voor vergelijkingen tussen universiteiten en voor analyses en prognoses op het niveau van bijvoorbeeld studierichtingen.

Om deze uniformiteit te kunnen waarborgen en een landelijke statistische database te kunnen bijhouden, dient een voorziening op landelijk niveau in het leven te worden geroepen. Deze landelijke voorziening kan bij voorkeur in een decentrale opzet uitvoering geven aan een landelijk uniforme wijze van dataverzameling en -verwerking. In een dergelijke opzet zorgen de afzonderlijke universiteiten voor het periodiek verzamelen en verwerken van de gegevens over hun afgestudeerden, alsmede voor het tijdig aanleveren van een basis-dataset aan de landelijke voorziening. De landelijke voorziening ziet er op toe dat de activiteiten binnen de afzonderlijke universiteiten op uniforme wijze worden verricht, coördineert deze activiteiten en actualiseert de landelijke statistische database. De landelijke voorziening dient tevens uitvoering te geven aan het periodieke onderzoek met betrekking tot de vraag naar afgestudeerden. Dit dient bij voorkeur in een centrale opzet te geschieden, waarbij de landelijke voorziening zorgt voor het periodiek verzamelen en verwerken van de gegevens met betrekking tot de vraagzijde van de arbeidsmarkt.

De database kan op tape aan een gespecialiseerd onderzoekinstituut ter beschikking worden gesteld voor het verrichten van analyses en het maken van 


$$
-v i-
$$

prognoses. De resultaten van de analyses en prognoses kunnen periodiek aan de eerder genoemde doelgroepen worden verstrekt in de vorm van voor hen passende standaardrapportages (wegwijzer, tabellenboek, rapport) of waar mogelijk in een gebruiksvriendelijk geautomatiseerde vorm. 
KORTE SAMENVATTING

In dit rapport wordt een informatiesysteem gepresenteerd waarmee gedetailleerde gegevens over de arbeidsmarkt voor afgestudeerden van een universitaire studierichting systematisch kunnen worden gegenereerd. Daartoe worden vragenlijsten ontwikkeld waarmee afgestudeerde academici en (potentiële) werkgevers periodiek kunnen worden bevraagd. Ook wordt stilgestaan bij de organisatievormen waarbinnen een dergelijk onderzoek kan plaatsvinden en de methoden waarmee de voortgebrachte gegevens op toegankelijke wijze kunnen worden gepresenteerd voor de verschillende doelgroepen. 


\section{INLEIDING}

\subsection{De probleemstelling van de pilotstudie}

De arbeidsmarkt is in de afgelopen jaren in toenemende mate onderwerp van studie geworden. Een belangrijk punt van aandacht daarbij is de aansluiting van het onderwijs op de arbeidsmarkt. Zeer uiteenlopende organisaties doen daar, om uiteenlopende redenen, onderzoek naar. Het vermoeden bestond dat hierdoor een schat aan data-materiaal zou zijn verzameld welke een nuttige aanvuliing zou kunnen vormen op onderzoeksgegevens over de nationale arbeidsmarkt. Met deze verfijnde dataset zouden dan vergelijkende en prognosticerende analyses op nationaal niveau of op het niveau van bijvoorbeeld studierichtingen kunnen worden verricht.

Een eerste inventarisatie van deze onderzoeken maakte echter duidelijk dat de meeste onderzoeksresultaten niet onderling vergelijkbaar zijn omdat er grote verschillen zijn in de gehanteerde onderzoeksmethoden. Deze verschillen hebben onder meer betrekking op de mate waarin en de wijze waarop contacten met bijvoorbeeld schoolverlaters en afgestudeerden worden onderhouden, de uiteenlopende wijzen warop essentiële begrippen worden gedefinieerd en geoperationaliseerd, en de niet vergelijkbare wijzen waarop onderzoeksresultaten worden geclassificeerd en gepresenteerd.

In een eerder rapport van het Researchcentrum voor Onderwijs en Arbeidsmarkt (ROA) zijn de resultaten weergegeven van een inventarisatie van onderzoeken onder afgestudeerden uit het wetenschappelijk onderwijs ${ }^{1}$. Tevens bevat dat rapport een beschrijving van een binnenlandse- en een buitenlandse organisatie die er wel in geslaagd zijn om jaarlijks en op grote schaal vergelijkbare gegevens over de arbeidsmarktpositie van afgestudeerden per universiteit en studierichting boven water te krijgen.

Met dergelijke gedetailleerde uitstroomgegevens van studierichtingen doen zich nieuwe mogelijkheden voor op het terrein van voorlichting, beleidsontwikkeling en -evaluatie en onderzoek. De huidige verzameling van arbeidsmarktgegevens op nationale schaal, middels de jaarlijkse Enquête Beroeps Bevolking (EBB) van het Centraal Bureau voor de Statistiek (CBS), is vanwege het steekproefkarakter ontoereikend om gefundeerde uitspraken te kunnen doen

1. Van Dam, De Grip, Heijke (1988). 
op het niveau van studierichtingen. Ook is de termijn tussen het moment van dataverzameling en het moment waarop de gegevens beschikbaar zijn voor analyse, erg lang. Deze bedraagt momenteel meer dan twee jaar. Een derde beperking van de EBB is gelegen in het feit dat deze geen informatie voortbrengt over de eerste bestemming van personen na het verlaten van een opleiding. Terwijl informatie hierover juist van groot belang is om inzicht in de aansluiting tussen het onderwijs en de arbeidsmarkt te verkrijgen.

Juist op dit moment echter, doen zich goede mogelijkheden voor om coördinatie in de gegevensverzameling door afzonderlijke universiteiten en faculteiten te bewerkstelligen. In het kader van de kwaliteitszorg voor het wetenschappelijk onderwijs worden externe visitatiecommissies in het leven geroepen. Hierbij moeten faculteiten een zogeheten 'zelfstudie' verrichten op basis waarvan een visitatiecommissie zich een oordeel kan vormen. Daarin dient uitgebreid aandacht te worden geschonken aan de relatie tussen het aangeboden onderwijs en het functioneren van de afgestudeerden op de arbeidsmarkt. In hoofdstuk 2 zal het bovenstaande verder worden toegelicht.

De voorgaande overwegingen leiden tot de behoefte aan onderzoek naar:

- de aanwezigheid van representatieve gegevens over de uitstroom uit het universitaire onderwijs, het huidige bestand van afgestudeerden en van de arbeidsmarktposities die zij vervullen of zouden kunnen vervullen;

- het ontwikkelen van systemen, modellen en procedures voor verkenningen van de toekomstige arbeidsmarktpositie van academici;

- het ontwikkelen van registratiesystemen en onderzoeksinstrumenten om de gegevensverzameling en de toekomstverkenningen met de nodige regelmaat te kunnen herhalen.

Het onderzoek zou vooral moeten zijn gericht op het ontwikkelen van een (standaard-) instrumentarium om de ontwikkelingen op de arbeidsmarkt voor academici op de voet te kunnen volgen (te 'scannen') en te voorspellen. De aanwezigheid van een standaard-instrumentarium zou het verrichten van dergelijk onderzoek moeten bevorderen en een waarborg moeten vormen voor de onderlinge vergelijkbaarheid van de onderzoeksresultaten. Door regelmatige herhaling van het voorgestelde loopbaan- en arbeidsmarktonderzoek onder afgestudeerden van zoveel mogelijk faculteiten zal een statistische dataset ontstaan die bruikbaar is voor landelijke analyses en prognoses op het niveau van bijvoorbeeld studierichtingen. 
Door het ROA werd aan het Ministerie van Onderwijs en Wetenschappen voorgesteld om eerst een pilotstudie uit te voeren naar een arbeidsmarktscanner voor een cluster van onderling samenhangende afstudeerrichtingen binnen één faculteit aan één universitaire instelling. Om doelmatigheidsredenen werd gekozen voor de Faculteit der Gezondheidswetenschappen (FdGW) van de Rijksuniversiteit Limburg $(R L)$. Bovendien kon bij deze pilotstudie gebruik worden gemaakt van de resultaten van een reeds verricht onderzoek onder afgestudeerden van een drietal afstudeerrichtingen van deze faculteit.

\subsection{De indeling van dit rapport}

In hoofdstuk 2 wordt eerst kort stilgestaan bij de rol die arbeidsmarktinformatie speelt bij de werking van de arbeidsmarkt en het optreden van werkloosheid. Vervolgens wordt ingegaan op de verschillende doelgroepen die belang hebben bij informatie over de aansluiting tussen opleiding en arbeidsmarkt, de door hen gewenste informatie en de motivatie die daaraan ten grondslag ligt. Vervolgens wordt stilgestaan bij de uitgangspunten en doelstellingen bij het ontwikkelen van een arbeidsmarktscanner, de gegevens die deze uiteindelijk moet opleveren en de voorwaarden waaraan de voortgebrachte informatie moet voldoen.

In hoofdstuk 3 worden de beschikbare statistische gegevens en de verrichte studies over de arbeidsmarkt van afgestudeerden in de gezondheidswetenschappen geëvalueerd. Daarbij zal vooral worden ingegaan op de vraag in hoeverre een secundaire analyse van CBS-statistieken, rapporten over de werkgelegenheidssituatie in de gezondheidszorg c.q. van gezondheidswetenschappers, en cijfers over de in- en uitstroom in het universitaire onderwijs, een beeld kunnen geven van de te verwachten ontwikkelingen op de arbeidsmarkt van afgestudeerde gezondheidswetenschappers.

In hoofdstuk 4 wordt een aantal methoden van enquêtering van academici met betrekking tot hun arbeidsmarktpositie beschreven en geëvalueerd. Hierbij gaat het om een inventarisatie en nadere analyse van de wijze van adresregistratie, de eventuele steekproeftrekking, de gehanteerde vragenlijsten, de wijze van benaderen, de onderzoekfrequentie, de presentatie van de resultaten, de bruikbaarheid van de verkregen gegevens voor analyses en prognoses, en de organisatie van het onderzoek. Met het oog hierop is de werkwijze geïnventariseerd van een aantal beroepsverenigingen, een universiteit en enkele faculteiten in Nederland en in twee Angelsaksische landen (Groot- 
Brittannië en de Canadese deelstaat Ontario).

In hoofdstuk 5 komt het ontwikkelen en testen van vragenlijsten voor de aanbodzijde van de arbeidsmarkt aan de orde. Hiermee moet informatie worden verkregen over de arbeidsmarktpositie van afgestudeerden, de functie en bedrijfstak waarin zij werkzaam zijn, hun carrièreverloop, de genoten aanvullende opleidingen, de betekenis van de genoten opleiding voor de beroepsuitoefening en dergelijke.

In hoofdstuk 6 komt het ontwikkelen van een vragenlijst voor de benadering van (potentiële) werkgevers aan de orde, zoals instellingen en bedrijven in de gezondheidszorg en aanverwante sectoren. Met deze vragenlijst, die jaarlijks in een korte versie en meerjaarlijks in een uitgebreide versie aan personeelsfunctionarissen wordt voorgelegd, wordt informatie verzameld over de huidige en de te verwachten samenstelling van het personeelsbestand naar functie, opleiding en leeftijd, over de wijzen van werving en selectie door werkgevers en over het door hen gevoerde loopbaan- en scholingsbeleid.

In hoofdstuk 7 wordt ingegaan op de voorziening die op universitair en landelijk niveau nodig is om systematisch en periodiek onderzoek onder afgestudeerden en werkgevers mogelijk te maken. Daarbij wordt ook gekeken naar het aanleggen en actueel houden van een zo volledig mogelijk adressenbestand van afgestudeerden en naar activiteiten om de respons hoog te houden.

Hoofdstuk 8 gaat in op de vorm en inhoud van standaardrapportages die kunnen voorzien in de informatiebehoefte van de diverse groepen belanghebbenden.

Dit rapport wordt afgesloten met een aantal bijlagen. Daarin zijn ook de ontwikkelde vragenkaarten met de bijbehorende toelichtingen opgenomen. 


\section{DE RELEVANTIE VAN INFORMATIE OVER ONDERWIJS EN ARBEIDSMARKT}

\subsection{Inleiding}

Actuele en gedetailleerde informatie over ontwikkelingen op de arbeidsmarkt is om verschillende redenen en voor verschillende actoren van groot belang. In dit hoofdstuk wordt kort stilgestaan bij het belang van dergelijke informatie voor het functioneren van de arbeidsmarkt. Vervolgens wordt uitgebreider ingegaan op de behoefte aan informatie over de arbeidsmarkt bij diverse belanghebbenden. Hieruit wordt een aantal 'kern'-gegevens gedestilleerd die met behulp van de te ontwikkelen arbeidsmarktscanner moeten worden voortgebracht. In de laatste paragraaf wordt ingegaan op de te stellen randvoorwaarden aan het datamateriaal.

\subsection{Arbeidsmarktfricties en enkele oorzaken van discrepanties}

De huidige situatie op de arbeidsmarkt ${ }^{2}$ wordt nog steeds gekenmerkt door een omvangrijke werkloosheid. Deze is te onderscheiden in verschillende componenten. In 1983, toen de werkloosheid bijna op zijn hoogst was, bedroeg het aandeel van de conjuncturele werkloosheid circa 25 procent. Het aandeel van de structurele werkloosheid (dit is de werkloosheid door onvoldoende productiecapaciteit) bedroeg circa 55 procent. Circa 20 procent van de totale werkloosheid was het gevolg van arbeidsmarktimperfecties. Dit is de werkloosheid die veroorzaakt wordt doordat de aard van de vraag en de aard van het aanbod niet adequaat op elkaar aansluiten of doordat vraag en aanbod elkaar niet (tijdig genoeg) weten te vinden.

De relatief geringe omvang van de werkloosheid als gevolg van arbeidsmarktimperfecties verhult enigszins het potentiële belang van deze werkloosheidscomponent. Zo deden zich in de tweede helft van de jaren zeventig, ondanks de oplopende werkloosheid, knelpunten voor in de vorm van grote tekorten aan vakmensen in verschillende arbeidsmarktsectoren. Muysken 3 heeft berekend dat de relatieve betekenis van marktimperfecties voor de omvang van de werkloosheid in de periode 1967-1981 sterk is verminderd, zij het dat in absolute termen sprake is van een verdubbeling tot ongeveer 130.000 arbeidsjaren. De

2. Deze paragraaf vormt een verkorte weergave van SER $(88 / 10)$, Bijlage 3, blz. 115 e.v.

3. Muysken (1984), blz. 193-217. 
omvang van de werkloosheid als gevolg van imperfecties blijkt dus zeer groot te zijn. Een verbetering van de werking van de arbeidsmarkt zou dan ook, alhoewel dit geen direkte bijdrage levert aan de creatie van werkgelegenheid, een substantiële bijdrage kunnen leveren aan de vermindering van de werkloosheid.

Een deel van de frictiewerkloosheid is ongetwijfeld het gevolg van het niet goed op elkaar aansluiten van de opleidingsstructuur van het aanbod van arbeid op de opleidingsstructuur van de vraag. Deze gebrekkige aansluiting is onder meer het gevolg van de relatieve autonomie van de technologische veranderingsprocessen in de economie en de weerslag daarvan in functiestructuren en gestelde opleidingseisen. De hierdoor veroorzaakte veranderingen in de opleidingsstructuur van de vraag gaan aanzienlijk sneller dan de door demografische factoren en de gemaakte opleidingskeuzen in het onderwijs veranderende opleidingsstructuur van de beroepsbevolking. De aansluitingsproblematiek brengt enkele gevolgen met zich mee die deze problematiek nog verder kunnen verergeren, zoals 4 :

a. neerwaartse verdringing, waarbij hogere opleidingseisen voor bepaalde functies slechts het gevolg zijn van de ruime beschikbaarheid van hoger gekwalificeerde arbeidskrachten op de arbeidsmarkt en niet omdat de inhoud van de functies is veranderd;

b. de vernietiging van human capital door langdurige werkloosheid;

c. de vertraagde doordringing van marktsignalen in het onderwijstraject.

Laatstgenoemde factor kan het optreden van varkenscycli tot gevolg hebben. De uitstroom uit het onderwijs kan nu eenmaal slechts met vertraging van enkele jaren reageren op signalen betreffende verschuivingen in de vraag naar bepaalde arbeidscategorieën. Deze signalen zijn bovendien niet altijd even duidelijk.

Om dergelijke imperfecties-veroorzakende processen tijdig te kunnen waarnemen en te volgen in de tijd dient nauwkeurige arbeidsmarktinformatie periodiek ter beschikking te komen. Deze informatie vormt een eerste vereiste voor beleidsmaatregelen ter bestrijding van imperfecties. Daarbij zijn diverse actoren betrokken met specifieke informatiebehoeften. In de volgende paragraaf wordt stilgestaan bij een aantal groeperingen dat belang heeft bij informatie over de arbeidsmarkt van academici, in het bijzonder

4. Zie ook De Grip (1987). 
met betrekking tot de door hen gevolgde opleiding.

\subsection{Belanghebbenden bij informatie over de arbeidsmarkt voor academici}

Het systematisch en periodiek beschikbaar komen van informatie over de positie van afgestudeerden op de arbeidsmarkt en het verloop van hun beroepscarrière kan een belangrijke bijdrage leveren aan:

- het traceren en extrapoleren van de structurele trends op de arbeidsmarkt, om zodoende tijdig te kunnen anticiperen op deze trends;

- het vaststellen van de vereiste opleidingscapaciteit van bestaande en nieuw op te zetten curricula;

- het evalueren van de opzet en de inrichting van de bestaande curricula;

- het mede vaststellen van de opzet en de inrichting van nieuwe curricula;

- het informeren van (aankomende) studenten, afgestudeerden, onderwijsgevenden en werkgevers over de arbeidsmarkt- en beroepsmogelijkheden van de verschillende studie- en afstudeerrichtingen.

Uit bovenstaand overzicht van toepassingsgebieden kunnen mogelijke groepen belanghebbenden en hun informatiebehoefte worden afgeleid. De behoefte aan informatie is niet voor alle groepen gelijk maar varieert naar gelang van de desbetreffende groep.

Tot de belanghebbenden behoren niet alleen onderzoekers die deze gegevens nodig hebben om analyses te kunnen verrichten en prognoses te kunnen maken op het niveau van studie/afstudeerrichtingen, maar ook en vooral de gebruikers van de analyse- en prognoseresultaten. De resultaten van dergelijke analyses en prognoses kunnen onder meer worden gebruikt bij de studie- en beroepskeuze, de arbeidsbemiddeling, de personeelsplanning, de capaciteitsplanning van het onderwijs, de opzet en inrichting van curricula, alsmede de kwaliteitsbewaking van het onderwijs 5 .

Overigens hebben de gebruikers van analyse- en prognoseresultaten zowel op individueel niveau als in georganiseerd verband (bijvoorbeeld verenigingen van afgestudeerden, beroeps- en bedrijfsverenigingen, branche-organisaties) behoefte aan informatie.

5. Zie ook ROA-R-1989/1. 


\section{Onderzoekers}

Onderzoekers op het gebied van onderwijs en arbeidsmarkt hebben een geactualiseerd bestand van gegevens over de arbeidsmarkt voor academici nodig dat bruikbaar is voor analyses en prognoses op een relatief laag aggregatieniveau zoals een bepaalde studierichting. In dit kader kan worden gewezen op het informatiesysteem voor onderwijs en arbeidsmarkt dat door het ROA in opdracht van het Ministerie van Onderwijs en Wetenschappen wordt ontwikkeld. Met dit informatiesysteem worden twee belangrijke doelen gediend, namelijk "scannen" en prognosticeren. Onder "scannen" wordt verstaan dat de actuele ontwikkeling in de aansluiting van afzonderlijke opleidingen op de arbeidsmarkt permanent en zo nauwkeurig mogelijk wordt gevolgd. Naast het scannen van actuele ontwikkelingen moet het informatiesysteem ook voorzien in kwantitatief onderbouwde prognoses van de arbeidsmarktperspectieven van opleidingen en beroepen.

In het ROA-onderzoeksprogramma 1989-1990 getiteld Naar een informatiesysteem onderwijs-arbeidsmarkt (ROA-R-1989/1) wordt ingegaan op de potentiële gebruiksmogelijkheden van een dergelijk informatiesysteem. Tevens wordt daarin uiteengezet op welke wijze wordt gewerkt aan de totstandkoming ervan. Een belangrijke plaats wordt daarbij ingenomen door de basisgegevens waarmee de econometrische prognosemodellen worden gevoed. De belangrijkste "input" wordt vooralsnog gevorma door de statistische gegevens uit de Arbeidskrachtentelling ( $A K T$ ) en Enquête Beroepsbevolking (EBB) van het CBS. Het betreft gegevens over de aantallen werkenden naar functie, bedrijfstak, opleiding, leeftijd en arbeidsduur. Vanwege het steekproefkarakter is de EBB (voorheen AKT genoemd) echter ontoereikend om gefundeerde uitspraken te kunnen doen over de arbeidsmarkt- en beroepsmogelijkheden op een relatief laag aggregatieniveau als bijvoorbeeld een bepaalde studierichting. Het is dan ook van groot belang dat statistische gegevens beschikbaar komen die differentiatie naar afzonderlijke studierichtingen wel toelaten, zoals de gegevens van de onderzoeken onder academici die kunnen worden gegenereerd met behulp van het in dit rapport voorgestelde onderzoekinstrument. Op basis van periodiek en systematisch arbeidsmarktonderzoek onder academici en werkgevers ontstaat een statistische database waarmee econometrische prognosemodellen kunnen worden gevoed die gefundeerde uitspraken over de toekomstige arbeidsmarkt- en beroepsmogelijkheden op het niveau van een bepaalde studierichting wel toelaten. 


\section{Gebruikers van analyse- en prognoseresultaten}

Zoals eerder is opgemerkt kunnen de analyse- en prognoseresultaten van arbeidsmarktonderzoek onder afgestudeerden en werkgevers worden gebruikt bij onder meer de studie- en beroepskeuze, de arbeidsbemiddeling, de personeelsplanning, de capaciteitsplanning van het onderwijs, de opzet en inrichting van curricula, alsmede de kwaliteitsbewaking van het onderwijs.

Kiezers van een studie of beroep en degenen die hierbij een voorlichtende taak hebben, hebben behoefte aan informatie over de (toekomstige) kansen op werk, de (toekomstige) beroepsmogelijkheden, het te verwerven inkomen en de carrièremogelijkheden na het volgen van de verschillende opleidingen. De overheid heeft belang bij informatie over de arbeidsmarktpositie van academici aangezien zij, als bekostiger van het wetenschappelijk onderwijs en verantwoordelijke voor het arbeidsvoorzieningenbeleid, het tot haar taak rekent om zorg te dragen voor een optimale aansluiting tussen vraag en aanbod op de arbeidsmarkt. Werkgevers, waartoe ook de overheid behoort, hebben behoefte aan informatie over de toekomstige uitstroom uit de verschillende opleidingen en de mogelijkheden van deze opleidingen tijdens de beroepsuitoefening ten behoeve van het realiseren van een doelmatige personeel sopbouw.

Voor universiteiten en faculteiten zijn arbeidsmarktgegevens over hun opleidingen van belang voor de bepaling van de capaciteit van de onderwijsvoorzieningen, de inrichting van het onderwijs en de kwaliteitsbewaking van het onderwijs. Capaciteitsplanners in het onderwijs hebben informatie nodig waarmee de capaciteit van de verschillende opleidingen beter kan worden afgestemd op de mogelijkheden van de arbeidsmarkt. Het betreft met name kwantitatieve gegevens over de omvang en samenstelling van de toekomstige uitstroom uit de diverse opleidingen en de vraag op de arbeidsmarkt naar deze opleidingen. Onderwijsgevenden en ontwerpers van curricula hebben vooral behoefte aan informatie waarmee zij het onderwijs inhoudelijk beter kunnen afstemmen op de eisen van de beroepspraktijk. Het gaat hierbij om kwalitatieve informatie over beroepsprofielen, functie-uitoefening en de daarvoor benodigde kennis en vaardigheden.

In het Hoger Onderwijs en Onderzoek Plan (HOOP) uit 1988 wordt ten behoeve van de kwaliteitsbewaking van het hoger onderwijs een belangrijke plaats toegekend aan de instellingen zelf. Dit wordt in de Gids externe kwaliteits- 
zorg van de Vereniging van Samenwerkende Nederlandse Universiteiten (VSNU) verder uitgewerkt. Onder "externe kwaliteitszorg" wordt de kwaliteitsbeoordeling van het onderwijs door externe visitatiecommissies begrepen. Deze externe commissies zouden onder meer op basis van een zogeheten "zelfstudie" van de betreffende faculteit een oordeel over de kwaliteit van het onderwijs moeten geven. Volgens de aanwijzingen voor de inhoud van deze zelfstudie dient in de rapportage ook aandacht te worden geschonken aan de afgestudeerden. De volgende punten zouden volgens het opgestelde protocol aan de orde kunnen komen met betrekking tot de afgestudeerden 6 :

- Worden er vanuit het afnemende veld eisen geformuleerd waaraan de afgestudeerde moet voldoen?

- Is er sprake van duidelijke beroepsprofielen?

- Is daar in de loop der tijd wijziging in opgetreden?

- Waar komen de afgestudeerden terecht?

- Hoe staat het met de werkloosheid onder de afgestudeerden?

- Heeft men contacten met de alumni?

- Wat is de mening van de alumni over de opleiding?

- Zijn er structurele of incidentele contacten met het afnemende veld?

- Hoe is het beleid om de opleiding zo goed mogelijk op de arbeidsmarkt af te stemmen?

In hoeverre in de zelfstudies van de afzonderlijke faculteiten wordt ingegaan op bovengenoemde vragen is nog niet duidelijk. Gevreesd moet worden dat de resultaten van dit onderdeel van de visitaties nauwelijks of niet met elkaar zijn te vergelijken. Er ontbreken namelijk afspraken over een uniforme wijze van verzamelen en verwerken van de gegevens die nodig zijn om dergelijke vragen te kunnen beantwoorden. Met behulp van het onderzoekinstrument dat in dit rapport wordt gepresenteerd zouden de resultaten van dit onderdeel van de visitaties bij de afzonderlijke faculteiten wel vergelijkbaar zijn.

\subsection{Benodigde gegevens}

Hoewel het niet precies dezelfde informatie is waar de genoemde groepen behoefte aan hebben, is er echter wel een opsomming te geven van het soort arbeidsmarktgegevens dat in een gemeenschappelijke prioritaire behoefte zou

6. Vereniging van Samenwerkende Nederlandse Universiteiten, (1988). 
voorzien. Het gaat dan om informatie over:

- de kansen op werk na het verlaten van de opleiding, in het bijzonder in de beroepsdomeinen waarop de desbetreffende opleidingen beogen aan te sluiten;

- het te verwerven inkomen, de arbeidsvoorwäarden en de carrièremogelijkheden in deze beroepsdomeinen;

- de doelmatigheid van de opleiding in relatie tot de eisen die de beroepsuitoefening stelt;

- de omvang en samenstelling van de toekomstige uitstroom uit de diverse opleidingen.

Om de bovenstaande informatie te kunnen verstrekken, dient zowel over de aanbod- als de vraagzijde een aantal gegevens te worden verzameld. Deze kunnen worden voortgebracht met behulp van de ontwikkelde arbeidsmarktscanner.

Voor de aanbodzijde zullen per afgestudeerde in ieder geval de volgende gegevens nodig zijn:

- Gegevens over het 'onderwijsverleden' van de afgestudeerde, in het bijzonder over de laatstgevolgde studie- en afstudeerrichting.

- Gegevens over de 'eerste bestemming' na het afronden van de opleiding. Hierbij kan worden gedacht aan de belangrijkste soort bezigheden die een afgestudeerde één jaar na het afronden van de studie verricht.

Vervolgens indien men werkzaam is:

- Gegevens over de functie waarin men werkzaam is. Gedacht moet worden aan de benaming van de functie, de belangrijkste werkzaamheden, het functieniveau en of men leiding moet geven.

- Gegevens over de werkgever waarvoor men werkzaam is. Het betreft het soort bedrijf of instelling waarvoor men werkt, het belangrijkste produkt of dienst dat geleverd wordt, de plaats van vestiging en het aantal personen dat bij die werkgever werkzaam is.

- Gegevens over de wijze waarop men in contact is gekomen met de huidige werkgever en de aard van de arbeidsovereenkomst.

- Gegevens over de arbeidsvoorwaarden.

- Gegevens over aanvullende opleidingen.

En indien men niet werkzaam is (volgens de definities van de International Labour Organisation): 
- Gegevens over de reden waarom men werkloos is, over de wijze waarop men zich oriënteert op de arbeidsmarkt en over aanvullende opleidingen.

Over de vraagzijde zijn, per werkgever, de volgende gegevens van belang:

- Werkgeverskenmerken, zoals het aantal personeelsleden, de bruto loonsom, en de bedrijfstak waartoe de organisatie kan worden gerekend.

- Gegevens over het totaal aantal hoger opgeleiden dat men in dienst heeft, gespecificeerd naar opleidingsniveau en studie- en afstudeerrichting.

- Gegevens over de personele samenstelling naar functie en de opleiding en de leeftijd van de vervullers van die functies.

\subsection{Randvoorwaarden}

Er is een aantal randvoorwaarden waaraan de resultaten van de arbeidsmarktenquêtes dienen te voldoen om een bruikbare aanvulling te vormen op de bestaande CBS-bestanden. Deze randvoorwaarden luiden als volgt?:

\section{a. Representativiteit}

Vanzelfsprekend kunnen alleen die cijfers worden gebruikt die op een sociaal-wetenschappelijk verantwoorde wijze zijn verzameld en bewerkt. Zo dienen de onderzoekspopulaties een getrouwe afspiegeling te vormen van de totale populatie waarover gegevens worden verzameld. Tevens dient de wijze waarop de gegevens worden verzameld, te voldoen aan de methodische vereisten van validiteit en betrouwbaarheid. De wijze waarop de meetresultaten worden verwerkt dient statistisch verantwoord te zijn.

\section{b. Consistentie}

Onder consistentie van het datamateriaal wordt verstaan dat er geen sprake is van witte vlekken en dubbeltellingen. Tevens dient de vraagstelling een logische samenhang te hebben.

C. Koppelbaar aan andere bestanden

Een belangrijk criterium wordt gevormd door de vraag of de aanvullende gegevens wel op een dusdanige wijze zijn geordend en ingedeeld dat een vergelijking met elders gehanteerde indelingen mogelijk is. Hier wordt gedoeld op de onderlinge koppelbaarheid van de bestanden. Deze wordt zoveel mogelijk gewaarborgd als er gebruik wordt gemaakt van nationaal en

7. Zie ook Van Dam cs. (1988). 
internationaal gehanteerde definities en classificaties voor begrippen als 'werkzaam', 'werkloos' en voor beroep, opleiding en bedrijfstak waarin men werkzaam is. Het uitgangspunt dient te worden gevormd door de standaardclassificaties van het CBS die op hun beurt weer zijn geënt op internationale classificaties. Toch zijn ook deze classificaties voor een aantal sectoren te beperkt. Met name voor de collectieve sector, waarin relatief veel academici werkzaam zijn, zullen de bestaande CBSclassificaties verder moeten worden gedifferentieerd.

d. Actualiteit

Een vierde criterium wordt gevormd door de actualiteit van het datamateriaal. Meer dan twee jaar oude data zijn, vanwege de snelle ontwikkelingen op de arbeidsmarkt, nauwelijks nog zelfstandig bruikbaar voor analyse. Dit is veel minder het geval indien het gaat om de resultaten van een regelmatig herhaalde meting, die onderling vergelijkbaar zijn. In dat geval kunnen tijdreeksanalyses zeer nuttige inzichten opleveren.

e. Toegankelijkheid

Een criterium dat weinig toelichting behoeft is dat van de toegankelijkheid voor secundaire analyse. Dit is meer een praktisch dan een wetenschappelijk criterium. Niettemin blijken formele en praktische belemmeringen dikwijls een onoverkomelijk struikelblok te vormen.

f. Herhaling

Het arbeidsmarktonderzoek dat met het ontwikkelde instrumentarium verricht zal worden, zal met regelmaat dienen te worden herhaald. De ontwikkelingen in het betreffende arbeidsmarktsegment moeten regelmatig op dezelfde wijze in kaart worden gebracht ('gescanned'). Zo ontstaat een dataset waarmee tijdreeksanalyses en -prognoses kunnen worden verricht. 
䉂 


\section{OPLEIDING EN ARBEIDSMARKT VAN GEZONDHEIDSWETENSCHAPPERS}

\subsection{Inleiding}

In dit hoofdstuk wordt dieper ingegaan op de noodzaak om de arbeidsmarkt van afgestudeerde gezondheidswetenschappers regelmatig in kaart te brengen ("te scannen"). Dit is om verschillende redenen van belang. De snelle veranderingen in de gezondheidszorg, die ook belangrijke gevolgen hebben voor de vraag naar hoger geschoold personeel, maken het voor de opleidingen in de gezondheidswetenschappen noodzakelijk om voortdurend te kunnen beschikken over up-to-date gehouden gegevens over de arbeidsmarktpositie van hun afgestudeerden. Naast het op de voet volgen van de arbeidsmarktimplicaties van de veranderingen in de gezondheidszorg, is het van belang om te anticiperen op de toekomstige ontwikkelingen door het opzetten van een gerichte onderwijs- en manpowerplanning. Ook de hiervoor noodzakelijke planningsmodellen vereisen een systematische verzameling van gegevens over de arbeidsmarktpositie en het carrièreverloop van afgestudeerden van opleidingen die op de gezondheidssector zijn gericht, waaronder die in de gezondheidswetenschappen.

Om de arbeidsmarktpositie van afgestudeerden in de gezondheidswetenschappen te kunnen schetsen zijn gegevens nodig over de beschikbare arbeidsplaatsen waarin gezondheidswetenschappers werkzaam kunnen zijn, de werkzame beroepsbeoefenaren met een opleiding in de gezondheidswetenschappen en de instroom en uitstroom van opleidingen in de gezondheidswetenschappen of van daarmee vergelijkbare opleidingen.

In paragraaf 3.3. komt de vraag aan de orde of de ontwikkelingen op de arbeidsmarkt van gezondheidswetenschappers kunnen worden beschreven aan de hand van beschikbare studies en databestanden. Daartoe zal eerst in paragraaf 3.2. een korte schets worden gegeven van de gezondheidszorg in Nederland. Vervolgens komen in paragraaf 3.4. de diverse opleidingen in de gezondheidswetenschappen ter sprake. In paragraaf 3.5. zal worden ingegaan op de beschikbaarheid van kwantitatieve gegevens om een cijfermatig beeld te kunnen schetsen van de ontwikkelingen in het aantal arbeidsplaatsen en in het aantal beroepsbeoefenaren. 


\subsection{Ontwikkelingen in de gezondheidszorg in Nederland}

Het stelsel van gezondheidszorg in Nederland bestaat uit een groot aantal voorzieningen die op een ingewikkelde wijze met elkaar samenhangen. Een samenvattende weergave van een veel gebruikte indeling van deze voorzieningen ziet er als volgt uit8:

\section{Schema 1. Soorten voorzieningen in de gezondheidszorg}

1. Intra- en semimuraal:

- Ziekenhuizen, algemeen, academisch en categoriaal

- Psychiatrische ziekenhuizen, zwakzinnigeninrichtingen

- Verpleeghuizen

- Overige instellingen voor intramurale zorg

2. Medisch-specialisten (zelfstandig declarerend)

3. Extramuraal:

- Beroepsbeoefenaren: huisartsen, tandartsen, fysiotherapeuten

- Instellingen: kruiswerk (wijkverpleging), gezinsverzorging

4. Genees - en hulpmiddelen

5. Collectieve preventie: bedrijfs- en basisgezondheidsdiensten

6. Organisaties van beleid en beheer en ambulancevervoer

Deze groepen van voorzieningen behoren grotendeels tot de bedrijfsklasse "gezondheids- en veterinaire diensten" (klasse 93) - ook wel als "medische diensten" aangeduid - van de Standaard Bedrijfsindeling (SBI) van het CBS. Enkele instellingen uit het bovenstaande overzicht behoren volgens de SBI echter tot de "maatschappelijke dienstverlening" (klasse 94), terwijl de ziekenfondsen onder de bedrijfsklasse "openbaar bestuur, defensie en wettelijke sociale verzekering" vallen (klasse 90). In de praktijk komt het er op neer dat de CBS-cijfers, mits gebaseerd op de SBI, een smallere basis hebben dan de cijfers van het Ministerie van Welzijn, Volksgezondheid en Cultuur (WVC), dat zich op bovenvermelde indeling van de gezondheidszorg baseert. Het grote verschil tussen deze twee indelingen betekent dat bij een vergelijking van de cijfers over de gezondheidszorg goed gekeken moet worden naar het onderdeel van zorg waarop ze precies betrekking hebben.

In het Financieel overzicht zorg ${ }^{9}$ is het kostenverloop van de zorgsector

8. Onder meer in het Financieel Overzicht Zorg dat jaarlijks verschijnt als bijlage bij de begroting van het Ministerie van WVC.

9. Tweede Kamer der Staten Generaal (1989), blz. 12. 
over de periode 1982-1987 weergegeven. Uit dit overzicht (zie tabel 1.) kan worden afgeleid dat de kosten in die periode met gemiddeld $2,8 \%$ per jaar zijn toegenomen tot 43,7 miljard gulden in 1987 , dat wil zeggen $10,1 \%$ van het BNP. Van 1975 tot 1982 was er zelfs sprake van een gemiddelde jaarlijkse groei van 9\%. Nadere beschouwing leert dat de uitgavengroei van 1982 tot 1987 vooral is te wijten aan de relatief zeer sterk gestegen uitgaven voor farmaceutische hulp en voor kunst- en hulpmiddelen van gemiddeld $8,2 \%$ per jaar. Eveneens opmerkelijk is de groei in de kosten voor beheer en ziekenvervoer. De toename van de beheerskosten is deels het gevolg van de invoering van de Wet Tarieven Gezondheidszorg en van de budgettering van de uitgaven in de gezondheidszorg.

Tabel 1. Kosten van de zorgsector 1982-1987

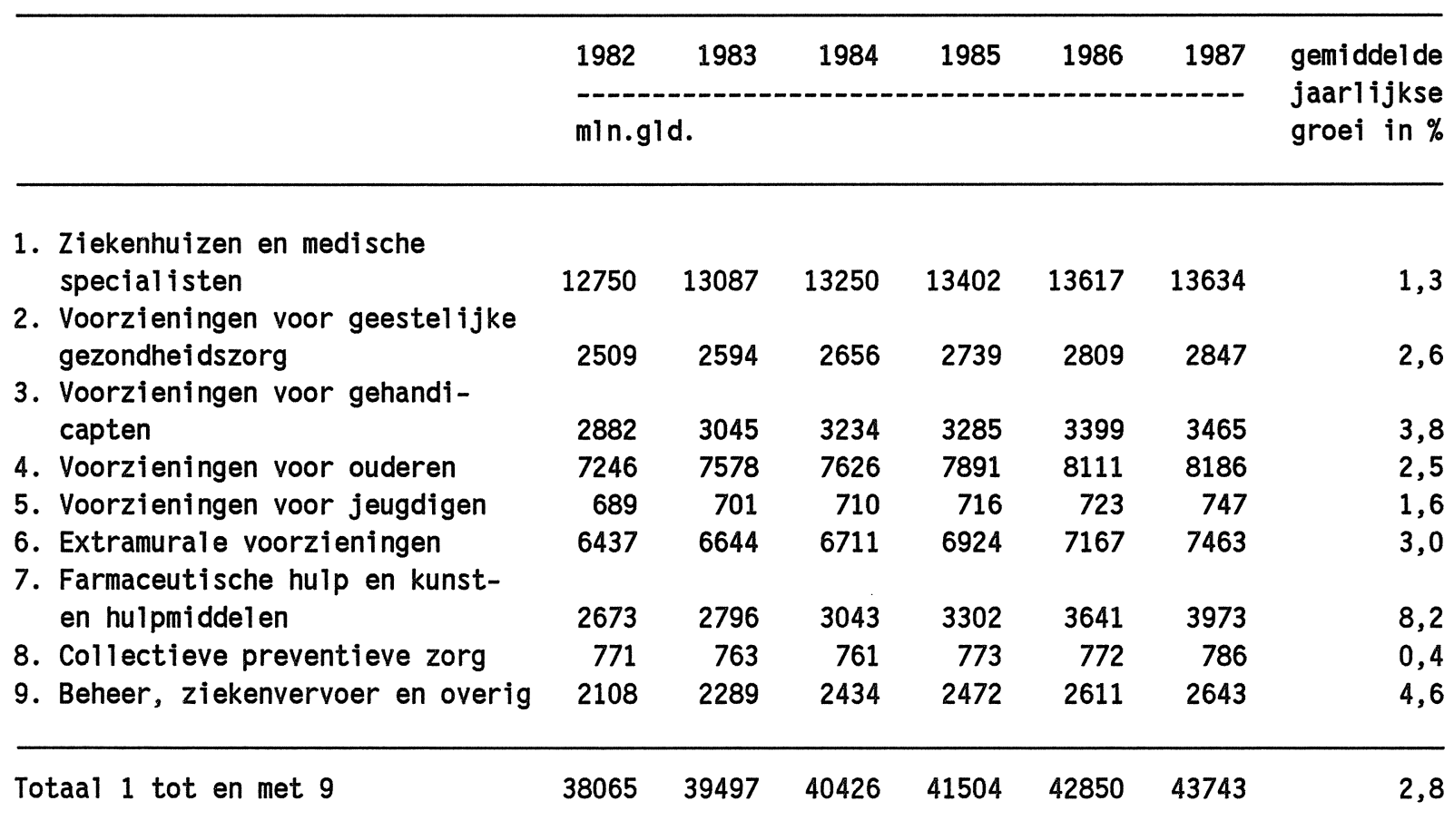

Voor de explosieve groej van de uitgaven aan gezondheidszorg noemt van der Maesen 10 onder meer als oorzaken:

- De veranderingen in de levensstijl en de levenssituatie. Enerzijds is deze veel riskanter geworden in verband met het verkeer, de eet- en drinkgewoonten, het gebruik van genotmiddelen enz., en anderzijds is er een tendens tot individualisering waardoor de zorg in afnemende mate door familie en bekenden en in toenemende mate door professionals en instanties wordt verricht.

10. Van der Maesen (1987), blz. 9-15. 
- De nog steeds toenemende vergrijzing. De sterke toename van bejaarden leidt, mede gezien de toenemende individualisering, tot een stijging van de vraag naar verzorgende- en verplegende instellingen voor ouderen.

De enorme groei van de uitgaven voor gezondheidszorg in ons land is vergelijkbaar met de ontwikkelingen in andere westerse landen. Zo bedroeg het gemiddelde in de landen van de Organisatie voor Economische Samenwerking en Ontwikkeling in $19604,1 \%$ en in $19837,6 \% 11$.

In het rapport van de Wetenschappelijke Raad voor het Regeringsbeleid (WRR) Ruimte voor groei (1987) wordt het arbeidsvolume in de bedrijfsklasse gezondheidszorg in 1983 op 321.000 arbeidsjaren geschat. Voor de klasse maatschappelijke dienstverlening, die qua uitgaven en arbeidsvolume voor circa $70 \%$ wordt gedomineerd door de voorzieningen voor bejaarden en de gezinsverzorging, raamt de WRR een werkgelegenheid van ongeveer 157.000 arbeidsjaren (220.000 banen, waarvan 70.000 met een werkweek van minder dan 15 uur) 12 .

In het Trendrapport kwartaire sector is de volgende tabel opgenomen 13 : Tabel 2. Personeel gezondheidszorg 1975-1983

\begin{tabular}{lrrrrr}
\hline & 1975 & 1980 & 1981 & 1982 & 1983 \\
\hline $\begin{array}{l}\text { intramurale gezondheidszorg } \\
\text { personeel (x1000) } \\
\text { index }\end{array}$ & 200,1 & 228,7 & 233,7 & 237,1 & 237,4 \\
$\begin{array}{l}\text { extramurale gezondheidszorg } \\
\text { personeel (x1000) } \\
\text { index }\end{array}$ & 84 & 96 & 98 & 100 & 100 \\
$\begin{array}{l}\text { ziekenfondsen } \\
\text { personeel (x1000) } \\
\text { index }\end{array}$ & 36,4 & 47,5 & 50,3 & 52,8 & 54,2 \\
$\begin{array}{l}\text { totaal } \\
\text { personeel (x1000) }\end{array}$ & 67 & 88 & 93 & 98 & 100 \\
$\quad$ index & 5,3 & 6,5 & 7,1 & 7,5 & 7,9 \\
\hline
\end{tabular}

11. Wetenschappelijke Raad voor het Regeringsbeleid (1987), blz. 223-224.

12. Wetenschappelijke Raad voor het Regeringsbeleid (1987), blz. 203-209 en 222.

13. Sociaal en Cultureel Planbureau (1984). 
Hieruit blijkt dat de personeelsomvang in de gezondheidszorg tussen 1975 en 1983 in totaal met $24 \%$ is toegenomen. De personeelssterkte is relatief het snelst gestegen bij de ziekenfondsen en bij de extramurale gezondheidszorg, die ongeveer twee mal zo snel groeiden als de intramurale zorg. Deze sterke stijging hangt zowel samen met het overheidsbeleid dat is gericht op versterking van de eerstelijnsgezondheidszorg als met de, wellicht daarmee samenhangende, groei van het aantal (vrije) beroepsbeoefenaren met een (para)-medische opleiding. In de beschouwde periode is de stijging van de personeelssterkte in de intramurale gezondheidszorg absoluut gezien echter nog het dubbele geweest van die in de extramurale gezondheidszorg. In 1983 is de personeelssterkte in de intramurale gezondheidszorg, mede onder invloed van de budgettering van de ziekenhuizen, vrijwel stabiel gebleven. Na 1983 is de personeelssterkte weer toegenomen. In 1987 waren er in de intramurale gezondheidszorg 310.000 mensen (waarvan 138.000 part-timers) werkzaam op 250.000 arbeidsplaatsen.

Voor de periode van 1983-1990 verwachtte het Sociaal en Cultureel Planbureau (SCP) een forse personeelstoename voor de gezondheidszorg. Volgens de basisraming zou er sprake zijn van een stijging van de personeelssterkte met bijna $9 \%$. In absolute termen zou dit een personeelstoename van ruim 26.000 arbeidsjaren betekenen. Met name in de intramurale gezondheidszorg zou de vergrijzing van de bevolking een grote rol gaan spelen bij de personeelstoename. Helaas zijn er in het Financieel overzicht zorg ' 89 geen cijfers te vinden over recente personele ontwikkelingen in de gehele gezondheidszorg waaraan de genoemde prognose van het SCP zou kunnen worden getoetst.

\subsection{Arbeidsmarkt en arbeidsplaatsen in de gezondheidszorg}

Zoals uit de vorige paragraaf is gebleken, is de gezondheidszorg de afgelopen decennia uitgegroeid tot een omvangrijke en complexe voorziening. Hierbij zijn nieuwe benaderingswijzen ontstaan. Steeds meer specialismen en vakgebieden buiten de geneeskunde zijn onderdeel gaan uitmaken van de gezondheidszorg. Daarbij wordt meer en meer gebruik gemaakt van wetenschappelijke methoden om de factoren die onze leefwijze, gedrag en gezondheid beïnvloeden te onderzoeken. Het aantal arbeidsplaatsen voor dergelijke nietmedische specialisten in de gezondheidszorg is in de afgelopen jaren fors toegenomen. Helaas is het nauwelijks mogelijk om de stijging van het aantal arbeidsplaatsen voor 'gezondheidswetenschappers' cijfermatig te onderbouwen. 
Dit heeft de volgende oorzaken:

- gezondheidswetenschappers vervullen betrekkelijk nieuwe functies;

- gezondheidswetenschappen is een verzamelnaam voor diverse disciplines;

- personeelsstatistieken maken gebruik van grove indelingen.

In deze paragraaf zal op dit gebrek aan gegevens nader worden ingegaan. Wij zullen daartoe de belangrijkste resultaten weergeven van een inventarisatie van de belangrijkste personeelsstatistieken en planningsmodellen en -rapporten voor de gezondheidszorg.

\section{Personeelsstatistieken:}

In de jaarlijks verschijnende publikatie De intramurale gezondheidszorg in cijfers van het Nationaal Ziekenhuisinstituut (NZI), wordt veel aandacht geschonken aan personeelsgegevens. Jaarlijks wordt door de afdeling statistiek van het NZI een omvangrijke vragenlijst verzonden naar alle instellingen voor intramurale gezondheidszorg. De resultaten daarvan worden weergegeven in De statistiek personeelssterkte 19xx, landelijke tabellen. In deze vragenlijst worden acht hoofdgroepen van personeel onderscheiden. Eén daarvan is de 'medische en sociaal-wetenschappelijke staf'. Helaas is dit de enige groep die niet verder wordt gespecificeerd, in tegenstelling tot de zeven andere hoofdgroepen die soms enkele tientallen sub-categorieën bevatten. Hierdoor zijn specifieke functies bij intramurale instellingen, die worden vervuld door gezondheidswetenschappers, niet te achterhalen. Bij het NZI wordt verwacht dat over enkele jaren ook de hoofdgroep 'medische en sociaal-wetenschappelijke staf' verder zal worden gespecificeerd. Overigens betreffen de NZI-statistieken het aantal werkzame personen en niet het aantal formatieplaatsen.

Het Nederlands Instituut voor Onderzoek van de Eerstelijnsgezondheidszorg (NIVEL) heeft een registratiesysteem opgezet voor beroepsbeoefenaren in de eerstelijnsgezondheidszorg. Het betreft onder meer huisartsen, verloskundigen en fysiotherapeuten. Hoewel ook deze gegevens van belang zijn voor het verkrijgen van een beeld van de personele ontwikkelingen in de gezondheidszorg, bevatten ze geen relevante gegevens met betrekking tot de arbeidsmarkt voor gezondheidswetenschappers. 
De CBS-afdeling 'Statistieken van de gezondheidszorg' verwerkt de gegevens die door de geneeskundige hoofdinspectie en het NZI zijn verzameld. Dit gebeurt met name ten behoeve van diverse ministeries, onder meer ter onderbouwing van het eerder genoemde Financieel overzicht zorg. Alleen voor de intramurale gezondheidszorg is een samenhangend overzicht van personeelsgegevens te verkrijgen. Onderlinge vergelijking van gegevens over instellingen uit de extramurale gezondheidszorg is niet mogelijk in verband met witte plekken en dubbeltellingen 14 .

\section{Modellen:}

Voor een inventarisatie van de beschikbare gegevens over de arbeidsmarktontwikkelingen en -prognoses voor de gezondheidszorg is, naast personeelsstatistieken, ook de ontwikkeling van de modelbouw voor de manpowerplanning in de gezondheidszorg van belang.

Om de ontwikkelingen van het gebruik van de gezondheidszorgvoorzieningen en de daaraan gekoppelde personeelsbehoefte in de gezondheidszorg te kunnen schetsen, is door het Centraal Plan Bureau in 1981 het econometrische model MEDIKA (MEDIsche Kosten en Arbeid) ontwikkeld15. MEDIKA biedt inzicht in de achterliggende factoren die in het verleden de ontwikkelingen in de gezondheidszorg hebben bepaald. De cijfers waarop de personeelsramingen worden gebaseerd zijn afkomstig van het CBS. Met het model zouden de gevolgen van het overheidsbeleid voor de werkgelegenheid en de kosten in de gezondheidszorg kunnen worden berekend. In Publikatie nr. 5 van het Project Personeelsvoorziening Kwartaire Sector is dit ook daadwerkelijk gedaan. De resultaten hiervan zijn, te samen met resultaten van eerdere ramingen voor andere delen van de kwartaire sector, opgenomen in de hierna te bespreken rapporten van de Commissie Harmonisatie Ramingen Kwartaire Sector (1983) en het Sociaal en Cultureel Planbureau (1984). MEDIKA wordt thans niet meer gebruikt en heeft ook geen opvolger gekregen. De modelbouw voor de gezondheidszorg staat nagenoeg stil.

14. Telefonische mededeling van medewerker Afdeling Gezondheidsstatistieken van het CBS.

15. Zie ook Sociaal en Cultureel Planbureau/Centraal Planbureau (1984). 
Rapporten met analyses en prognoses:

Naast de hiervoor genoemde statistieken en het econometrische model MEDIKA is in de afgelopen jaren nog een aantal belangrijke rapporten met analyses en prognoses verschenen.

Het jaarlijks als bijlage bij de WVC-begroting verschijnende Financieel overzicht zorg bevat cijfers en analyses van de ontwikkeling van het personeel en de zorgcapaciteit in de achterliggende vijf jaren. Daarnaast bevat het een taakstellend financieel kader voor de beide zorgsectoren in de komende jaren. Deze cijfers zijn afkomstig van het CBS en het Ministerie van WVC. Er wordt wel onderscheid gemaakt in de personeelsontwikkeling van verschillende deelsectoren maar niet van functies. Geconcludeerd kan worden dat ook hiermee geen goed beeld is te geven van de arbeidsmarktperspectieven van gezondheidswetenschappers.

In 1983 en 1984 verschenen twee rapporten waarin prognoses zijn gemaakt van de personeelsomvang van de gezondheidszorg. Het gaat om respectievelijk het eindrapport van de commissie Harmonisatie Ramingen Kwartaire Sector (HARK), getiteld Over voorzieningen- gebruik en personeel in de kwartaire sector 1983-1987, en het eerder genoemde Trendrapport kwartaire sector 1983-1990 van het Sociaal en Cultureel Planbureau.

Beide rapporten bevatten prognoses voor een periode van vier tot zes jaar ten behoeve van de interdepartementale commissie 'planvorming kwartaire sector', de opvolger van de commissie-HARK. Deze ramingen zijn gebaseerd op het trendmatig gebruik dat van elke voorziening wordt gemaakt, daarbij rekening houdend met de demografische ontwikkeling en uitgaande van een constante personeelsinzet per gebruiker of gebruikseenheid op het niveau van 1983.

Beide studies zijn gebaseerd op statistische gegevens van het CBS. Tevens wordt in beide rapporten gebruik gemaakt van een indeling die is afgeleid van het Financieel overzicht zorg, hetgeen impliceert dat wel ontwikkelingen in sectoren maar niet van functies of functiegroepen zijn weergegeven. 
De notitie Taakstellingen beroepskrachtenplanning gezondheidszorg van juli 1988 dient ter voorbereiding op de vierde nota Beroepskrachtenplanning gezondheidszorg van de Nationale Raad voor de Volksgezondheid. Dergelijke nota's worden sedert 1987 om het andere jaar aan de Tweede Kamer aangeboden. In de voorbereidende notitie wordt de toelatingscapaciteit vastgesteld voor een aantal medische-, paramedische- en verpleegkundige opleidingen. Daartoe worden per beroepsgroep de (te verwachten) ontwikkelingen in de vraag naar en het aanbod van beroepsbeoefenaren geschetst.

De hiervoor benodigde gegevens zijn voor de intramurale zorg grotendeels afkomstig van het NZI en voor de extramurale zorg van het CBS. Verder wordt gebruik gemaakt van publikaties van het NIVEL en de registraties van beroepsorganisaties en de Geneeskundige Hoofd Inspectie (GHI). Voor de arbeidsmarktontwikkeling voor gezondheidswetenschappers zijn de gegevens over sociaal-geneeskundigen uit de hoofdcategorie 'medische beroepen' deels van belang.

Het voorgaande in overweging nemend lijkt de conclusie gerechtvaardigd dat met behulp van de belangrijkste statistieken, modellen en rapporten over de arbeidsmarktaspecten van de gezondheidszorg niet is te achterhalen hoe het momenteel is gesteld met de arbeidsmarkt voor gezondheidswetenschappers en hoe deze zich op middellange termijn zal ontwikkelen. Op grond van beleidsnota's echter kan worden gesteld dat er sprake is van een groeiende vraag.

\subsection{Opleidingen voor gezondheidswetenschappers in Nederland}

Om een beeld te kunnen geven van de arbeidsmarktperspectieven van afgestudeerde gezondheidswetenschappers zijn niet alleen gegevens nodig over het aantal arbeidsplaatsen in de gezondheidszorg. Men zal ook gegevens moeten hebben over het beroepspotentieel dat momenteel nog in opleiding is. Na een korte inleiding zal in deze paragraaf een aantal stroomgegevens worden gegeven voor opleidingen in de gezondheidswetenschappen in Nederland. Achtereenvolgens wordt per studierichting aangegeven hoeveel studenten in het huidige studiejaar zijn begonnen met hun opleiding, hoeveel studenten in het studiejaar 1987/1988 met een diploma de betreffende opleiding hebben verlaten, of een studiestop voor het komende studiejaar is voorgesteld en of onderzoek is verricht onder afgestudeerden. 
Indien dit het geval is worden daarvan de belangrijkste resultaten weergegeven. Dit om de lezer een beeld te geven waar op de arbeidsmarkt de afgestudeerden uit de genoemde richting zoal terecht komen. In de volgende paragraaf zal de nadruk liggen op een inventarisatie van verricht arbeidsmarktonderzoek en bestaande onderwijsstatistieken.

Vóór 1980 bestond in Nederland geen specifieke universitaire opleiding voor professionele ondersteunende of management functies in de gezondheidszorg. Dit soort functies werd vervuld door geneeskundigen, fysici, chemici, technici en sociale wetenschappers.

De sterke groei van de gezondheidszorg aan het eind van de zeventiger en het begin van de tachtiger jaren leidde tot een toename van de behoefte aan professionele ondersteuning en beheersing. De vraag op de arbeidsmarkt om specialisering en professionalisering had tot gevolg dat bijvoorbeeld binnen het Wetenschappelijk Onderwijs nieuwe onderwijsprogramma's werden ontwikkeld. In eerste instantie gebeurde dit nog binnen de bestaande studierichtingen en faculteiten. Vanaf 1980 bestaat de mogelijkheid om gezondheidswetenschappen te studeren binnen een zelfstandige faculteit en wel aan de RL.

De gezondheidswetenschappen en gelijksoortige universitaire opleidingen beslaan een breed terrein. Er kan worden gekozen uit een scala van meer beta tot overwegend gamma gerichte studies. Het hieronder volgende overzicht is samengesteld aan de hand van studiegidsen, vrijgegeven resultaten van onderzoeken onder afgestudeerden en telefonische navraag. Bij de samenstelling van dit overzicht zijn de afstudeerrichtingen van de Faculteit der Gezondheidswetenschappen van de RL als uitgangspunt genomen.

\section{Beleid en beheer van gezondheidszorgvoorzieningen}

Deze afstudeerrichting kan worden gekozen aan de Faculteit der Gezondheidswetenschappen van de RL en de Faculteit Geneeskunde van de Erasmus Universiteit Rotterdam (EUR). 
Tabel 3. Beleid en beheer van gezondheidszorgvoorzieningen; stroomgegevens

RL

EUR

Aantal le jaars 1988-1989

83

100

Aantal alumni 1987-1988

40

ca. 50

Voorgestelde numerus fixus $1989-1990$

Onderzoek onder afgestudeerden verricht?

geen 100

$\mathrm{ja}^{16} \quad \mathrm{ja}:$ intern

Resultaten van het verrichte onderzoek:

Functies van afgestudeerden in beleid en beheer: 17

- Beleidsmedewerker

- Staffunctionaris

- Wetenschappel ijk medewerkers e.d.

- Bedrijfsadministratief medewerker

- Hoofd/leidinggevende/projectleider

- Financieel-economisch medewerker

Sectoren waarin zij het meest frequent werkzaam zijn:

- Tweedelijnsvoorzieningen

- Onderwijs- en onderzoeksinstellingen

- Overheden.

\section{Gezondheidsvoorlichting en -opvoeding}

Deze afstudeerrichting kan worden gekozen aan de Faculteit der Gezondheidswetenschappen van de RL. Ook studenten van de Faculteit Bewegingswetenschappen van de Rijksuniversiteit Groningen (RUG) en de Vakgroep Voorlichtingskunde van de Landbouw Universiteit Wageningen (LUW) kunnen voor gezondheidsvoorlichting en -opvoeding (GVO) kiezen.

16. Kramer en Schreurs (1988).

17. Percentages berekend op basis van primaire data van Kramer en Schreurs (1988). In totaal betrof het 67 werkzame afgestudeerden in Beleid en Beheer. 
Tabel 4. Gezondheidsvoorlichting en -opvoeding; stroomgegevens

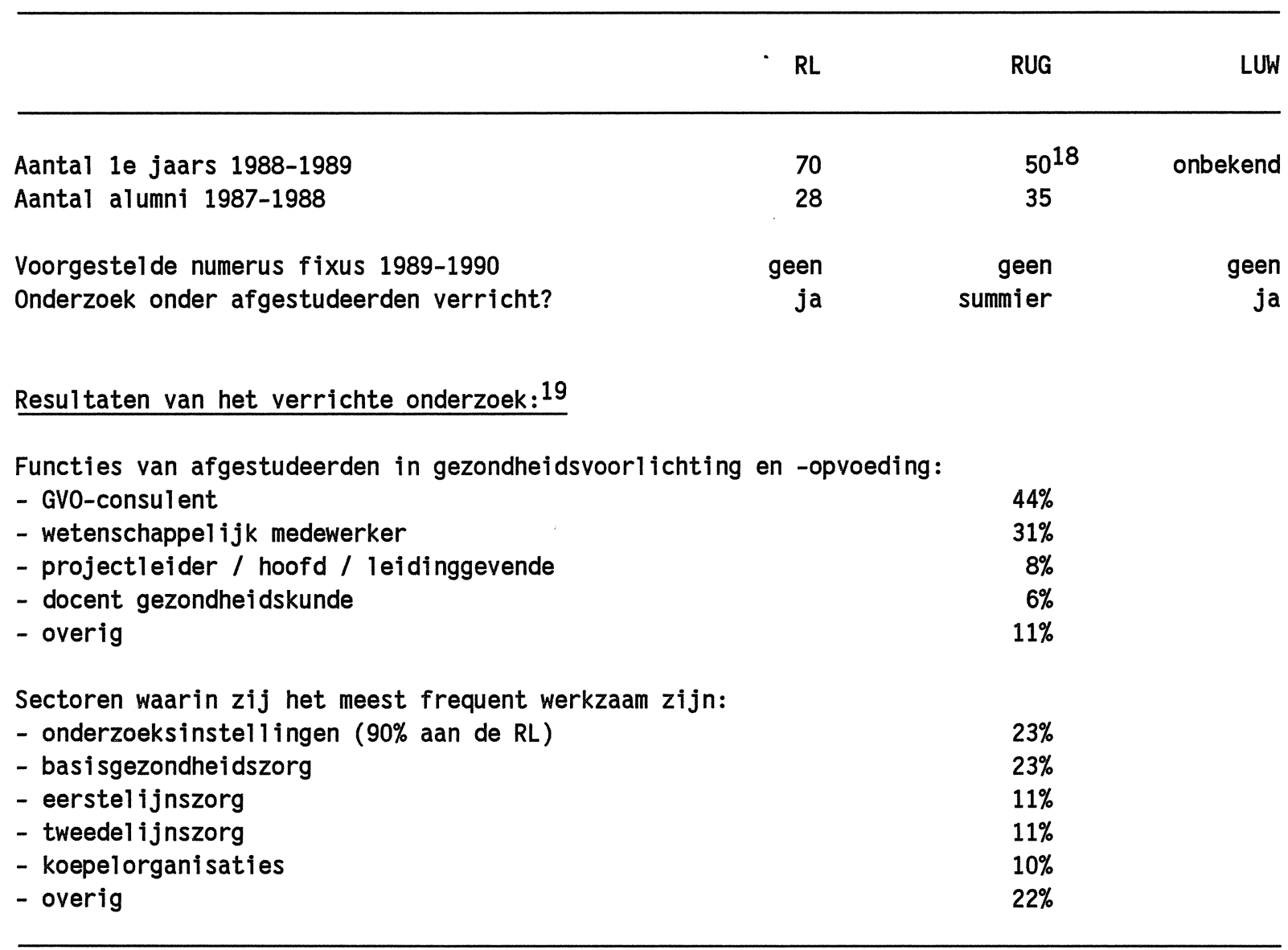

\section{Verplegingswetenschap}

Deze afstudeerrichting kan worden gekozen aan de Faculteit der Gezondheidswetenschappen van de $\mathrm{RL}$ en als experimentele deeltijdopleiding aan de Rijksuniversiteit Utrecht (RUU). Aan de Rijksuniversiteit Groningen is een werkgroep bezig om een soortgelijke opleiding op te zetten.

18. Het betreft het totaal aantal afgestudeerden die Bewegingswetenschappen hebben gekozen. Dus niet alleen met een GVO-specialisatie.

19. Kramer, Schreurs (1988). Resultaten berekend op basis van primaire data van 52 werkzame afgestudeerden in GVO. 
Tabel 5. Verplegingswetenschap; stroomgegevens

RL

Aantal 1e jaars 1988-1989

20

Aantal alumni 1987-1988

Voorgestelde numerus fixus 1989-1990

geen

Onderzoek onder afgestudeerden verricht?

n.v.t.

\section{Resultaten van het verrichte onderzoek:}

Functies van afgestudeerde verplegingswetenschappers:

- wetenschappelijk medewerker (70\% aan RL) $42 \%$

- hoofd / leidinggevende / projectleider 25\%

- stafmedewerker $21 \%$

- overig (oa. beleidsmedewerker, artsenbezoeker) 12\%

Sectoren waarin zij het meest frequent werkzaam zijn:

- tweedelijnszorg (ziekenhuizen) $33 \%$

- (onderwijs-) en onderzoeksinstellingen ( $88 \% \mathrm{RL}$ ) $33 \%$

- eerstelijnszorg $13 \%$

$\begin{array}{ll}\text { - overig } 20 \% & \end{array}$

\section{Geestelijke gezondheidkunde}

Vanaf 1984 bestaat aan de Faculteit der Gezondheidswetenschappen van de RL de mogelijkheid om geestelijke gezondheidkunde als afstudeerrichting te kiezen. Deze of een vergelijkbare afstudeerrichting kan aan geen andere universiteit worden gekozen. Aangezien er in het studiejaar 1987/88 pas twee studenten in deze richting afstudeerden kunnen nog geen cijfers worden gegeven over de functies en sectoren waarin zij terecht komen. Wel bestaat er een relatie met de studierichting $k l i n i s c h e$ psychologie.

Tabel 6. Geestelijke gezondheidkunde; stroomgegevens

RL 


\section{Bewegingswetenschappen}

Deze afstudeerrichting kan aan verschillende universiteiten worden gekozen. Vanaf 1971 heeft de Vrije Universiteit (VU) een studierichting bewegingswetenschappen, verbonden aan de Interfaculteit Lichamelijke Opvoeding (IFLO). De Rijksuniversiteit Groningen kent de vrije studierichting bewegingsopvoeding en -behandeling aan de subfaculteit Pedagogische Wetenschappen. Vanaf 1984 kan deze richting door studenten in de Faculteit der Gezondheidswetenschappen van de RL worden gekozen.

Tabe1 7. Bewegingswetenschappen; stroomgegevens

\begin{tabular}{lrrrr}
\hline & RL & KUN & RUG & VU (IFL0) \\
\hline Aantal 1e (2e) jaars 1988-1989 & 52 & $80(*)$ & $50(*)$ & 130 \\
Aantal alumni 1987-1988 & 12 & 7 & 35 & 55 (ns.) \\
& & 85 & 95 (os.) \\
Voorgestelde numerus fixus: & geen & $\begin{array}{r}\text { geen } \\
\text { ja20 }\end{array}$
\end{tabular}

\section{Resultaten van het verrichte onderzoek:}

Functies van afgestudeerde bewegingswetenschappers IFLO:

- docent

ca. $25 \%$

- therapeut

ca. $20 \%$

- wetenschappelijk medewerker

ca. $20 \%$

- beleidsmedewerker

ca. $10 \%$

- overig, wel relatie met bewegingswetenschappen

ca. $10 \%$

- overig, geen relatie met bewegingswetenschappen

ca. $15 \%$

Sectoren waarin zij het meest frequent werkzaam zijn:

- onderwijs en onderzoeksinstellingen

ca. $40 \%$

- universiteiten (onderzoeksfuncties)

ca. $10 \%$

- aan I.F.L.O. -opleiding zelf

ca. $10 \%$

- HBO/MBO (docentfuncties)

ca. $20 \%$

- tweedelijnszorg (ziekenhuizen)

ca. $15 \%$

- overheid

- bedrijfsleven

- instellingen in de gezondheidszorgsector

ca. $15 \%$

ca. $10 \%$

- instellingen in de welzijnssector

ca. $10 \%$

ca. $10 \%$

20. Wajon (1986). 


\section{Filosofie en theorie der gezondheidwetenschappen}

Deze afstudeerrichting kan sinds 1984 worden gekozen aan de Faculteit der Gezondheidswetenschappen van de RL. Hierin staat de systematische gedachtenvorming over de wetenschappelijke bestudering van gezondheid en ziekte centraal. Zij is mede opgezet als combinatierichting met de hiervoor genoemde afstudeerrichtingen.

\section{Biologische gezondheidkunde}

De afstudeerrichtingen biologische gezondheidkunde aan de RL en medische biologie aan de Rijksuniversiteit Utrecht lijken inhoudelijk veel op elkaar. Ook zijn er enkele medische faculteiten die onder de naam gezondheidswetenschappen een sterk hierop gelijkende afstudeerrichting aanbieden zoals de Katholieke Universiteit Nijmegen (KUN) en de Rijksuniversiteit Leiden (RUL). Bovendien kan aan de drie technische universiteiten nog worden gekozen voor biomedische technologie en bij de (sub)faculteiten biologie voor medische biologie.

Tabel 8. Biologische gezondheidkunde; stroomgegevens

\begin{tabular}{lrrrr}
\hline & RL & KUN & RUL & RUU \\
\hline Aantal 1e (2e) jaars 1988-1989 & 58 & 80 & 80 & 80 \\
Aantal alumni 1987-1988 & 8 & 7 & 2 & 1 \\
$\begin{array}{l}\text { Voorgestelde numerus fixus: } \\
\text { Onderzoek onder afgestudeerden verricht? }\end{array}$ & geen & 80 & 80 & 80 \\
& geen & geen & geen & geen \\
\hline
\end{tabular}

Aangezien medische biologie, verbonden aan (sub)faculteiten biologie, nauw verwant is met biologische gezondheidkunde volgen eveneens enkele gegevens van de opleiding medische biologie. 
Tabel 9. MEDISCHE BIOLOGIE, verbonden aan (sub)faculteiten biologie

$\begin{array}{llll}\text { Lokaties: } & \text { UVA, Amterdam } & \text { VU, Amsterdam } & \text { RUG, Groningen } \\ & \text { RUL, Leiden } & \text { KUN, Nijmegen } & \text { RUU, Utrecht }\end{array}$

Aantal studenten met specialisatie medische biologie (1988/89):

ca. 200

Resultaten van arbeidsmarktonderzoek medische biologie: 21

Functies voor medisch biologen en biologisch gezondheidkundigen:

- wetenschappelijk medewerker (onderzoeker)

- beleidsmedewerker, stafmedewerker

- docent

- adviseur / voorlichter

Sectoren waarin zij het meest frequent werkzaam zijn:

- onderwijs- en onderzoeksinstellingen

ca. $80 \%$

- universiteiten (onderzoeksfuncties)

ca. $55 \%$

- HBO-/MBO-opleidingen (docentfuncties)

ca. $10 \%$

- onderzoeksinstituten gezondheidszorg

ca. $15 \%$

- overheid

ca. $10 \%$

- bedrijfsleven (farmaceutische industrie)

ca. $10 \%$

Uit voorgaand overzicht kan worden geconcludeerd dat het aanbod van opleidingen met een gezondheidswetenschappelijk karakter, althans op papier, redelijk goed met elkaar is te vergelijken. Op grond van in- en uitstroomgegevens kan een globale indicatie worden geven van de kwantitatieve betekenis van de betreffende opleiding voor de arbeidsmarkt. Althans, voor wat betreft de omvang van het uitgestroomde contingent. Daarmee houden de vergelijkingsmogelijkheden echter op. Want hoewel er voor enkele opleidingen is nagegaan waar op de arbeidsmarkt de afgestudeerden zijn terecht gekomen, kunnen deze resultaten niet onderling worden vergeleken. In de volgende paragraaf zal hierop nader worden ingegaan.

\subsection{Data over gezondheidswetenschappers op de arbeidsmarkt}

In hoofdstuk 1 werd reeds aangegeven dat door tal van organisaties in Nederland gegevens worden verzameld over de arbeidsmarktpositie van academici. In deze paragraaf komen enkele publikaties met kwantitatieve gegevens over de onderwijsoutput aan bod alsmede een aantal onderzoeken die

21. Van Es e.a. (1988), Siebers (1987). 
zijn verricht onder afgestudeerden in de hiervoor beschreven studierichtingen. Naast een korte omschrijving van de publikatie of het onderzoek wordt ingegaan op de vraag of daarin relevante gegevens zijn opgenomen om de arbeidsmarktperspectieven van opleidingen in de gezondheidswetenschappen te kunnen schetsen.

\section{Statistiek van het Wetenschappelijk Onderwijs}

Het CBS geeft periodiek onderwijsstatistieken uit. In de jaarlijks verschijnende Mededelingen deelname gezondheidszorgopleidingen zijn gegevens over zowel de reguliere- als de in-service opleidingen in de gezondheidszorg opgenomen. Het aanbod van gezondheidswetenschappers op de arbeidsmarkt kan worden afgeleid uit de tabel Behaalde doctoraal-examens naar faculteit/studierichting22. Eén van de onderscheiden categorieën betreft 'overige medische studierichtingen' waartoe ook de gezondheidswetenschappen worden gerekend. In het cijfer voor gezondheidswetenschappers zijn gegevens opgenomen over opleidingen die in het Academisch Statuut als zodanig werden aangemerkt. Helaas wordt geen onderscheid gemaakt naar de verschillende afstudeerrichtingen. Nog bezwaarlijker is dat gegevens voor gezondheidswetenschappen in Maastricht en Leiden in één cijfer worden weergegeven. Hiermee verliest een dergelijk cijfer haar waarde als 'performance indicator' van elke afzonderlijke faculteit.

\section{Hoger Onderwijs en Onderzoek Plan: cijfers en ramingen}

Deel II van de in september 1987 verschenen ontwerpnota Hoger Onderwijs en Onderzoek Plan van het Ministerie van Onderwijs en Wetenschappen bevat een groot aantal statistieken23. Onder meer over de deelname aan het hoger onderwijs. Naast empirische gegevens van het CBS bevat deze nota ook prognoses tot het jaar 2000. Deze zijn ontleend aan de ramingen van de studentenaantallen in het wetenschappelijk onderwijs van de Taakgroep Studentenramingen24. Hoewel ook gegevens en ramingen zijn opgenomen voor 'gezondheidswetenschappen', is niet te achterhalen welke faculteiten en/of studierichtingen hiertoe behoren.

22. CBS (1988-II), blz. 48 en 49 .

23. Ministerie van Onderwijs en Wetenschappen (1987).

24. Taakgroep Studentenramingen (1986). 
Faculteit der Gezondheidswetenschappen, RL

Deze faculteit is in 1987 begonnen met een langlopend onderzoeksproject Beroepsperspectief van gezondheidswetenschappers met als doelstelling een continue terugkoppeling van gegevens over afgestudeerde gezondheidswetenschappers op de arbeidsmarkt naar de opleiding25. In mei 1988 verscheen het eerste rapport onder dezelfde titel met daarin de resultaten van een onderzoek onder alle 273 studenten die vanaf de oprichting in 1980 tot mei 1987 afstudeerden in de richtingen beleid en beheer, gezondheidsvoorlichting en -opvoeding of verplegingswetenschap. De respons op de schriftelijke enquête bedroeg na rappelering $67 \%$. De gehanteerde vragenlijst bevatte deels open en deels gesloten vragen. De antwoorden op de vragen naar het beroep en de bedrijfstak waarin men werkzaam is, zouden in principe kunnen worden hergecodeerd aan de hand van de CBS-standaardclassificaties.

Deze enquête zal worden herhaald onder alle studenten die na mei 1987 afstudeerden bij deze faculteit. De populatie van de uitstroomenquête van mei 1987 zal voor een follow-up interview worden benaderd. Vanaf het studiejaar 1988/1989 zal ook onder vierdejaarsstudenten jaarlijks een enquête worden gehouden over hun toekomstverwachtingen en ter evaluatie van de opleiding. Tenslotte zullen (potentiële) werkgevers worden benaderd met de vraag of gezondheidswetenschappers in aanmerking komen voor bepaalde functies in de betreffende organisatie. Het onderzoeksproject loopt tot september 1992.

De belangrijkste resultaten uit het rapport van mei 1988 waren als volgt. Van de 183 afgestudeerden heeft ruim driekwart een baan en is ruim een vijfde werk100s, waarvan $70 \%$ op zoek is naar een baan. Van de afgestudeerden in beleid en beheer heeft $84 \%$ een baan. Voor gezondheidsvoorlichting en -opvoeding en verplegingswetenschap is dit resp. $75 \%$ en $71 \%$. Ruim tweederde van de respondenten met een baan is werkzaam in een eerste functie na het afstuderen. Bijna een kwart van de groep werkenden is als wetenschappelijk assistent of als AIO verbonden aan de RL. Gemiddeld is eenvijfde werkzaam in de tweedelijnszorg en nog geen $10 \%$ in de basisgezondheidszorg, waar vooral afgestudeerden in de gezondheidsvoorlichting en -opvoeding werkzaam zijn. Aan voorzieningen voor de eerstelijnszorg is $9 \%$ van de werkenden verbonden.

25. Kramer en Schreurs (1988), blz. 4. 
Faculteit Bewegingswetenschappen (I.F.L.0.), Vrije Universiteit

In april 1986 is een eenmalig, verkennend onderzoek afgesloten naar de beroepsmogelijkheden voor afgestudeerden van de Faculteit der Bewegingswetenschappen aan de Vu26. Vanaf 1971 tot en met september 1985 waren dit 189 personen. Van 173 afgestudeerden kon worden achterhaald waar zij werkzaam zijn. De belangrijkste resultaten zijn weergegeven in het overzicht van de vorige paragraaf. De gegevens over beroep en bedrijf zijn niet te herleiden tot CBS-classificaties.

\section{(Medische) biologie}

De (sub)faculteiten biologie verzamelen eveneens gegevens over afgestudeerden of voeren een periodiek arbeidsmarktonderzoek onder afgestudeerden uit in samenwerking met het Nederlands Instituut van Biologen (NIBI). Het laatste NIBI-arbeidsmarktonderzoek betreft de afgestudeerde biologen uit het studiejaar 1985/198627. De respons van gemiddeld ca. $60 \%$ verschilt sterk per universiteit (tussen $48 \%$ en $74 \%$ ). Het totaal aantal respondenten bedraagt 488. De (sub)faculteiten biologie verzamelen de namen en adressen van de afgestudeerden uit een bepaald studiejaar en geven deze door aan het NIBI. Deze benadert hen met een vragenlijst. De resultaten worden regelmatig, doch niet jaarlijks, verwerkt. De onderzoeksvragen betreffen de specialisatierichting, de huidige werkzaamheden, de functiekenmerken, de vervolgopleiding en de nascholingsbehoeften. De definities en classificaties komen niet overeen met CBS-classificaties. Een aantal vragen is open zodat hercodering van de antwoorden in principe mogelijk is.

Uit het onderzoek onder afgestudeerden in de medische biologie in 1985-1986, blijkt dat er in de keuze van het hoofdvak een aanzienlijke verschuiving ten gunste van moleculaire biologie heeft plaats gevonden. Dit is niet verwonderlijk daar eveneens blijkt dat afgestudeerden in de laatst genoemde richting aanmerkelijk sneller een baan vinden dan afgestudeerden in andere medisch-biologische richtingen. Bovendien is er een aanzienlijke verschuiving te zien van onderwijs- naar onderzoeksbanen.

26. Wajon (1986).

27. Tichelaar (1987). 


\section{Rijksuniversiteit Leiden}

In 1985 is onderzoek verricht naar de arbeidsmarkt voor afgestudeerde gezondheidswetenschappers van de Rijksuniversiteit Leiden (RUL). Het onderzoek had de volgende doelstelling:

- vaststelling van het aantal wetenschappelijke onderzoekers dat thans actief is op de gebieden waarop de studierichting gezondheidswetenschappen van de RUL zich richt;

- definiëring van het gewenste profiel van de toekomstige afgestudeerde gezondheidswetenschappers;

- bepaling van de toekomstige behoefte aan afgestudeerden gezondheidswetenschappers.

Het betrof een eenmalig onderzoek waarin de gegevens zijn verzameld door middel van een enquête onder 24 sleutelinformanten. Deze respondentengroep vertegenwoordigt $15-30 \%$ van de markt warop de studierichting gezondheidswetenschappen van de RUL zich richt28.

Aan de Rijksuniversiteit Leiden is in 1987 voor de derde maal een enquête gehouden onder 119 afgestudeerde Leidse biologen (respons 87\%). Wat de onderzoeksmethode, onderzoeksvragen en onderzoeksitems betreft, wordt er nauw aangesloten bij de NIBI-enquête. De antwoorden op open vragen zijn derhalve te hercoderen tot CBS-classificaties 29.

\section{Onderzoek verricht door andere faculteiten}

Uit telefonische navraag bij de overige faculteiten en studierichtingen op het terrein van de gezondheidswetenschappen bleek dat een aantal zich bezighoudt met het verzamelen van gegevens over afgestudeerden. Zij waren echter of niet bereid, of niet in staat om deze gegevens ter beschikking te ste1len. In andere gevallen bleek het te gaan om zeer summiere resultaten.

\subsection{Conclusies}

In dit hoofdstuk is getracht om een beeld te geven van de arbeidsmarkt en de opleidingen voor gezondheidswetenschappers. De nadruk lag hierbij op de

28. Twijnstra Gudde N.V. (1986), blz. 1,5.

29. Siebers (1987). 
vraag óf goede kwantitatieve gegevens voorhanden zijn om een dergelijk beeld te kunnen schetsen en daarbij een vergelijking tussen de diverse opleidingen te kunnen maken. Geconstateerd moet worden dat aan bovenstaande doelstelling niet op adequate wijze kon worden voldaan. De oorzaak daarvoor is aan de ene kant het feit dat de aandachit voor de aansluiting van het onderwijs op de arbeidsmarkt een betrekkelijk nieuw fenomeen is. Aan de andere kant zijn de tot nu toe op dat terrein verrichte studies op een dusdanige wijze opgezet dat een onderlinge vergelijking van de resultaten niet mogelijk is. In de volgende hoofdstukken zal worden getracht een methodiek te ontwikkelen die in deze lacune voorziet. 


\section{EVALUATIE VAN METHODEN VAN ENQUETERING VAN AFGESTUDEERDEN}

\subsection{Inleiding}

In dit hoofdstuk komt de vraag aan de orde op welke wijze, door middel van enquêtes onder afgestudeerden, de arbeidsmarktpositie en loopbaanontwikkeling van afgestudeerde gezondheidswetenschappers het beste in kaart is te brengen. Dit zal in twee delen gebeuren. Eerst wordt beschreven wat de meest gehanteerde methoden voor 'first-destination surveys' en follow-up enquêtes zijn. Daarbij worden zowel Nederlandse als buitenlandse onderzoeken besproken. Vervolgens wordt aan de hand van een aantal criteria bekeken welke methode van dataverzameling en -bewerking de beste resultaten geeft.

In Nederland kunnen verschillende bronnen van gegevensverzameling worden onderscheiden. Zo zijn er onderwijsinstellingen die willen weten waar hun afgestudeerden op de arbeidsmarkt terecht zijn gekomen. Nauw daarmee verbonden zijn de verenigingen van afgestudeerden, die doorgaans aan één specifieke studierichting of opleiding zijn verbonden. Ten derde zijn er de beroepsverenigingen. Zij werken doorgaans op landelijk niveau en richten zich vooral op de belangenbehartiging van één of enkele beroepsgroepen met een enigszins vergelijkbare vooropleiding.

De buitenlandse studies die hier worden besproken zijn alleen de zogeheten 'first-destination surveys' of exit-enquêtes. Met name in de Angelsaksische landen heeft men hiermee ervaring. Wij beperken ons daarom tot de jaarlijkse first-destinations survey van de Association of Graduate Careers Advisory Services uit Groot-Brittannië en de vierjaarlijkse first-destinations survey van de 17 universiteiten van de Canadese deelstaat Quebec.

\subsection{Nederland}

\subsubsection{Organisatievormen}

In de inleiding van dit hoofdstuk is al een globale indeling gegeven van de verschillende soorten organisaties in Nederland die onderzoek verrichten onder afgestudeerden. Hieronder komen ze uitgebreider aan de orde.

- Universiteiten en aanverwante organisaties. Tot voor kort onderhielden de Nederlandse universiteiten geen contact met hun afgestudeerden. De Land- 
bouwuniversiteit Wageningen had als enige zicht op de arbeidsmarktpositie van haar afgestudeerden doordat twee aanverwante organisaties, het Nederlands Instituut van Landbouwkundig Ingenieurs en de Stichting Maatschappelijke Plaats Wageningse Afgestudeerden, gezamenlijk adressenlijsten samenstelden en up-to-date hielden. In het najaar van 1988 is de Universiteit Twente begonnen met de ledenorganisatie UT-Mediair. Afgestudeerden en (potentiële) werkgevers van afgestudeerden kunnen hiervan lid worden. Ook de Technische Universiteit Delft en de Erasmus Universiteit Rotterdam hebben concrete voornemens om een dergelijke 'ledenorganisatie' op poten te zetten. Aan de Rijksuniversiteit Groningen is onlangs een onderzoek onder enkele jaargangen recent afgestudeerden afgerond. Binnenkort zal aan de Katholieke Universiteit Nijmegen eenzelfde onderzoek worden verricht.

- Faculteiten en verenigingen van afgestudeerden. De laatstgenoemden zijn in deze groep opgenomen omdat ze doorgaans een faculteit als 'basis' hebben. Faculteiten houden zelden adressenbestanden bij van afgestudeerden. Dat wordt meestal overgelaten aan de desbetreffende verenigingen van afgestudeerden. Deze adressenbestanden vormen doorgaans het basismateriaal waarmee faculteiten of vakgroepen hun vragenlijsten aan afgestudeerden verzenden als er een enquête onder afgestudeerden wordt verricht. Nadeel hiervan is dat van de niet-aangeslotenen geen actueel adres meer bekend is, waardoor ze ook niet in het onderzoek kunnen worden opgenomen. Hierdoor kan een vertekend beeld optreden van de positie die afgestudeerden vervullen op de arbeidsmarkt. De verenigingen van afgestudeerden van economische en econometrische faculteiten houden een landelijke adreslijst bij en geven gezamenlijk 'Het Economenblad' uit.

- Beroepsverenigingen. Voor zover bekend zijn met name de beroepsverenigingen van medici, technici, landbouw- en natuurwetenschappers redelijk tot goed op de hoogte van de arbeidsmarktpositie van hun leden. Toch is er zowel bij deze als bij andere beroepsverenigingen een toenemende behoefte waar te nemen om daarnaast ook ontwikkelingen in het gehele arbeidsmarktsegment te registreren. Daarbij kan bijvoorbeeld worden gedacht aan het vroegtijdig signaleren van dreigende overschotten of tekorten.

Ten opzichte van de onderwijsinstellingen en de verenigingen van afgestudeerden hebben beroepsverenigingen het nadeel dat zij zich expliciet richten op diegenen die werkzaam zijn en dan ook nog alleen op diegenen die werkzaam zijn in het beroepsveld waarop de opleiding primair is gericht. Niet werkza- 
me personen of personen die in een geheel anderssoortige functie zijn terechtgekomen zullen doorgaans geen lid (meer) zijn van een dergelijke beroepsvereniging.

Daardoor geven de resultaten van het onderzoek dat door een beroepsvereniging onder de aangesloten leden wordt verricht geen bruikbaar inzicht in de aansluiting van het onderwijs op de arbeidsmarkt.

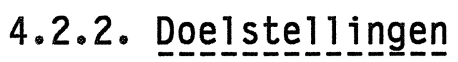

Algemene doelstellingen voor het bijhouden van een adressenbestand zijn dikwijls het verkrijgen van een overzicht van het ledenbestand en het onderhouden van contacten met de leden. Daarnaast kan een aantal specifieke doelstellingen worden genoemd.

Zo richten universiteiten, faculteiten en vakgroepen zich met hun exitenquêtes vooral op de evaluatie van het onderwijs, de vraag waar de afgestudeerden zijn terechtgekomen op de arbeidsmarkt en de vraag of het onderwijs ook aansluit op de beroepspraktijk. Deze onderzoeken zijn soms ook gericht op het in kaart brengen van de behoefte aan Post Academisch Onderwijs en het leggen en onderhouden van contacten met (potentiële) werkgevers. Het registreren van arbeidsmarktontwikkelingen en het opstellen van prognoses is voor universiteiten en faculteiten een nauwelijks voorkomende doelstelling, alhoewel daarin de laatste jaren wel een opwaartse kentering zichtbaar is.

Beroepsverenigingen daarentegen hebben, naast aandacht voor de kenmerken van opleidingen, functies en werkgevers, met name belangstelling voor de rechtsen inkomenspositie van hun leden.

Voor beroepsverenigingen, faculteiten en verenigingen van afgestudeerden kan naast de genoemde algemene doelstellingen tevens sprake zijn van een gezelligheidsmotief, zoals het instandhouden van een 'good-old boys' netwerk.

\subsubsection{Het_up-to-date houden}

Zoals eerder is opgemerkt worden door universiteiten en faculteiten zelden adressen van afgestudeerden bijgehouden. Wel beschikken zij over het ouderlijk adres en het studie-adres van hun studenten. Op het moment dat zij een 
enquête onder afgestudeerden willen gaan houden wordt een eerste mailing (al dan niet vooraf gegaan door telefonische recherche) naar één van deze adressen gezonden. Teneinde de non-respons te beperken wordt doorgaans geprobeerd om, middels telefonische recherche, een actueel adres te vinden. Bij de Rijksuniversiteit Groningen heeft men de non-respons via het arbeidsbureau, informele contacten en de burgerlijke stand van de gemeente weten te verkleinen. Voor een onderzoek met ad-hoc karakter wordt op deze wijze een zo bevredigend mogelijk adressenbestand samengesteld.

In tegenstelling tot de universiteiten en faculteiten gaan de meeste verenigingen van afgestudeerden, aan universiteiten verwante organisaties en beroepsverenigingen systematischer te werk. Het beheer van het adressenbestand is een onderdeel van de ledenadministratie en hangt samen met de inning van abonnements- of lidmaatschapsgelden. Er is doorgaans sprake van een wederzijds belang. Toetreding is vrijwillig en daarmee een afgeleide van dat belang. In het onderhouden van de contacten zijn globaal genomen twee vormen te onderscheiden.

1. Ofwel de organisatie is passief ten opzichte van de adresmutaties bij de leden. Er wordt alleen een wijziging in het bestand aangebracht als een lid daartoe het initiatief neemt, bijvoorbeeld door een adreswijziging door te geven.

2. Ofwel de organisatie is actief ten opzichte van de adresmutaties bij de leden. In dat geval wordt bijvoorbeeld jaarlijks een gegevenskaart verzonden waarop alleen de mutaties hoeven te worden aangebracht en die portvrij kan worden geretourneerd. Feedback naar de leden kan plaatsvinden door middel van een jaarlijkse adreslijst, een jaarboek of een almanak.

\subsubsection{Representatativiteit}

Welke gegevens aanwezig zijn en in welke mate van nauwkeurigheid is grotendeels afhankelijk van het soort organisatie, haar mogelijkheden en doelstellingen. De mate waarin de organisaties erin slagen om een volledig beeld te krijgen van hun potentiële ledenpopulatie is afhankelijk van de feitelijke organisatiegraad ten opzichte van de potentiële doelgroep. Dit kan aan de hand van het volgende voorbeeld worden geillustreerd. Veronderstel dat een aantal jaren geleden aan een bepaalde faculteit gedurende één studiejaar precies 100 personen afstudeerden en dat hiervan op dit moment nog 40 lid zijn van een vereniging van afgestudeerden. Een enquête onder deze 40 
personen, met een respons van bijvoorbeeld $60 \%$, leidt aldus tot 24 geretourneerde vragenlijsten. Het zal duidelijk zijn dat het wetenschappelijk niet verantwoord is om, op basis van deze 24 vragenlijsten, enige uitspraak te doen over de arbeidsmarktpositie van de betreffende jaargang afgestudeerden. Toch worden dergelijke pretenties in menig onderzoek gewekt.

Geen enkel adressenbestand of onderzoek heeft een 'dekkingspercentage' (=werkelijk bereikte populatie/potentiële of totale populatie) van $100 \%$. Van de geïnventariseerde onderzoeken onder afgestudeerde academici loopt de dekkingsgraad uiteen van $30 \%$ tot circa $70 \%$. Doordat onbekend is waar de niet-bereikte afgestudeerden op de arbeidsmarkt zijn terecht gekomen, kan niet vergeleken worden met de wèl bereikte afgestudeerden. Hierdoor kunnen geen 'harde' uitspraken over de representativiteit worden gedaan. Vooralsnog moet worden betwijfeld of de responsgroep een aselekte afspiegeling vormt van de totale populatie.

Een definitief oordeel over de representativiteit kan pas worden gegeven wanneer vergelijking met andere gegevens mogelijk is, of bij een aselekte steekproef uit de totale populatie. Hierbij kan worden gedacht aan de resultaten van de Arbeidskrachtentelling en de Enquête Beroepsbevolking.

\subsubsection{Onderzoeksmethoden en wijzze van verwerking}

Bij, op één na, alle gevonden onderzoeken onder afgestudeerden van het wetenschappelijk onderwijs is gebruik gemaakt van een schriftelijke enquête. Er zijn geen mondelinge interviews gehouden. Bij één onderzoek (onder 122 klinisch psychologen, UVA) heeft men informatie verzameld door een ongestruktureerde telefonische enquête.

De vragenlijsten die bij deze enquêtes werden gebruikt variëren nogal in lengte en opzet. Allen hebben ze grotendeels voorgecodeerde antwoordcategorieën. De meeste enquêtegegevens worden nog handmatig ingevoerd. Slechts bij één onderzoek wordt bij de verwerking gebruik gemaakt van optische leesapparatuur, de zogeheten 'optical mark reader'. Hoewel het invoeren van de enquêtegegevens hierdoor een stuk sneller gaat, stelt het hoge eisen aan de samenstelling en staat van het antwoordformulier en de wijze waarop de antwoordhokjes zijn ingevuld. Relatief veel antwoordformulieren worden niet of onjuist ingelezen. Dit leidt ertoe dat veel tijd moet worden besteed aan controle en correctie. De ingelezen binaire gegevens kunnen door middel van 
een conversieprogramma worden omgezet in decimale getallen waarop vervolgens statistische analyses kunnen worden toegepast.

\subsubsection{Onderzoeksvragen en -items}

Er zijn drie vragen die in vrijwel alle onderzoeken aan de orde komen:

- heeft men (betaald) werk?;

- zo ja, wat voor werk?;

- bij welke (soort) werkgever?

Dit zijn ook de belangrijkste drie vragen waarvoor de wijze van definiëring van de vragen en de classificering van de antwoorden van belang is. Dit zal in de volgende sub-paragraaf worden behandeld. Naast bovengenoemde vragen komen de volgende items in één of meerdere onderzoeken voor:

Persoonskenmerken:

- geslacht;

- leeftijd;

- burgerlijke staat.

Opleidingskenmerken:

- jaar waarop met de studie werd begonnen;

- jaar van afstuderen;

- afstudeerrichting;

- (hoofd) doktoraalvakken;

- promotie;

- belangrijkste nevenacitiviteiten tijdens de studie;

- andere/ aanvullende opleiding of cursussen;

- concurrerende opleiding(-en);

- onderwijsevaluatie;

- gemiste aspecten in de opleiding;

- (PAO-) wensen.

Indien zonder inkomen uit arbeid:

- actuele arbeidsmarktpositie;

- indien werkloos: belangrijkste (vermeende) oorzaak;

- indien werkloos: staat men als zodanig geregistreerd;

- aantal malen gesolliciteerd;

- wijzen waarop werd gesolliciteerd; 
- (meestgenoemde) reden van afwijzing.

Functie- en carrièrekenmerken:

- termijn en wijze waarop het werk is gevonden;

- aard van de belangrijkste werkzaamheden;

- inhoud van het werk;

- soort werkgever waar men werkzaam is;

- aard van de betrekking;

- arbeidssatisfactie;

- carrièreperspectieven.

Mobiliteit:

- aantal malen dat men van baan veranderde;

- redenen voor baanverandering;

- verwachtingen/wensen ten aanzien van baanverandering.

Arbeidsvoorwaarden:

- salaris en toeslagen;

- pensioenvoorwaarden;

- opleidingsfaciliteiten;

- flexibele werktijden.

\subsubsection{Definities en classificaties}

De mate waarin gebruik is gemaakt van dekkende en elkaar uitsluitende definities en classificaties kan worden beschouwd als een belangrijke indicator voor de zorgvuldigheid waarmee de diverse onderzoeken zijn opgezet. Bovendien zijn de gehanteerde definities en classificaties in hoge mate bepalend voor de bruikbaarheid van de onderzoeksresultaten voor secundaire analyses.

\section{Definitie van werkgelegenheid}

De meeste van de gevonden onderzoeken hanteren geen nauwkeurig omschreven definitie van werkgelegenheid. Hierdoor wordt de vergelijkbaarheid met andere onderzoeksresultaten en databestanden erg bemoeilijkt.

Vragen naar de situatie op de arbeidsmarkt variëren van een primitieve vraagstelling als "heeft u een baan?" of "heeft u een betalde functie?", 
zonder verdere aanduiding, tot een uitgebalanceerd stelsel van vragen en antwoordmogelijkheden waardoor de actuele arbeidsmarktpositie van de respondent nauwkeurig in kaart kan worden gebracht.

Een goed voorbeeld van een nauwkeurige vraagstelling treffen we aan bij de vijfjaarlijkse loopbaanonderzoeken van de Stichting Maatschappelijke Plaats Wageningse Afgestudeerden (MPW). Ter vaststelling van het soort positie dat de respondent inneemt op de arbeidsmarkt, wordt de gesloten vraag "Wat was uw situatie op 1-9-1983?" voorgelegd met 10 antwoordcategorieën en een nauwkeurige omschrijving van een aantal essentiële begrippen. Zo worden òfwel in de vragenlijst zelf, òfwel in de toelichting op de vragenlijst, begrippen als functie, tijdelijke funktie en vaste funktie, free-lance werk en pro deo werk gedefinieerd.

Door een nauwkeurige vraagstelling is het mogelijk om eenduidig vast te stellen of iemand ook werkelijk als werkloos dient te worden aangemerkt. Dat is volgens de officiële richtlijnen van de International Labour Organisation (ILO) het geval indien iemand geen betaalde werkzaamheden verricht, daar wel actief en daadwerkelijk naar op zoek is en bovendien direct beschikbaar is om dat werk te verrichten. In de MPW-vragenlijst zouden diegenen die kiezen voor de antwoordcategorie "Zonder betaalde functie, WEL werkzoekend", dus niet als zodanig kunnen worden aangemerkt, omdat zij dan zowel AKTIEF werkzoekend als DIREKT beschikbaar voor een arbeidsplaats zouden moeten zijn.

In hoofdstuk 5 zal worden aangegeven welke voorwaarden dienen te worden gesteld aan de te hanteren vragenlijsten. De vragenlijsten zullen in hoofdstuk 5 en 6 worden ontwikkeld. Daarbij zal verder worden ingegaan op de hierboven gesignaleerde definitiekwestie.

\section{Classificatie van beroepen en bedrijfstakken}

Uit een inventarisatie van de ons bekende onderzoeken bleek dat de bruikbaarheid van de resultaten niet alleen negatief wordt beïnvloed door het hanteren van verschillende definities. Bij vrijwel alle gevonden enquêteonderzoeken wordt gebruik gemaakt van vragenlijsten met gesloten antwoorden. Dit wordt met name gedaan voor de vragen naar het soort bedrijfstak waarin men werkzaam is en het soort functie dat wordt uitgeoefend. Hiervoor zijn doorgaans zeer globale indelingen ontworpen met een vijftal of zestal cate- 
gorieën, zoals "overheid", "bedrijfsleven", "onderwijs" enzovoorts. In een aantal gevallen is de classificatie toegespitst op de specifieke situatie van de onderzoekspopulatie. In dat geval zijn de naar verwachting veel voorkomende werkgeverscategorieën verder opgesplitst. Zo zijn in een onderzoek naar de arbeidsmarktpositie van afgestudeerden van de rechtenfaculteit (EUR) de sectoren "overheid", "onderwijs" en "typisch juridische sector" verder opgesplitst.

Het spreekt vanzelf dat onderzoekresultaten die zijn geordend met behulp van dergelijke zelf-ontworpen classificaties, nauwelijks bruikbaar zijn voor secundaire analyse. Zeker niet indien de hiervoor vereiste basisgegevens niet meer beschikbaar zijn voor hercodering.

In een aantal gevallen zijn deze basisgegevens nog wel voorhanden. Zo zijn bij enkele verenigingen van afgestudeerden en beroepsverenigingen de gegevens over opleiding, functie en werkgever ook in ongecodeerde vorm aanwezig. Bij sommige onderzoeken is voor de genoemde kenmerken een open vraag opgenomen en heeft codering en classificatie achteraf plaatsgevonden. In die gevallen zijn de gegevens nog voor elk gewenst doel te gebruiken.

\subsection{Buitenland: Groot-Brittannië en Ontario}

\subsubsection{Inleiding}

Voorzover bekend is de Landbouw Universiteit Wageningen de enige universiteit in ons land die met regelmaat contacten onderhoudt met haar afgestudeerden, hoewel inmiddels ook aan andere universiteiten plannen daartoe worden ontwikkeld. Het gevaar dreigt echter dat iedere universiteit er een eigen wijze van registreren en onderzoeken op na gaat houden. Het is alleen al om deze reden nuttig om eens te bekijken hoe men er zowel in GrootBrittannië als in Ontario in slaagt om van alle universiteiten en 'polytechnics' uniforme informatie over de arbeidsmarktpositie van afgestudeerden te verkrijgen. Hoewel van veel universiteiten in de Angelsaksische landen bekend is dat ze first-destinations surveys verrichten, is ons alleen van de twee bovengenoemde landen bekend dat ze op een nationaal niveau c.q. deelstaat-niveau plaatsvinden. 


\subsubsection{First-destinations survey in Groot-Brittannië}

\section{Jaarlijkse enquête}

In Groot-Brittannië wordt aan het eind van elk kalenderjaar aan alle afgestudeerden uit het voorgaande studiejaar een vragenlijst toegezonden. Dit wordt gedaan door de aan elke universiteit verbonden Careers Advisory Service (CAS). De organisatie van de dataverzameling en -verwerking is in handen van de Association of Graduate Careers Advisory Services (AGCAS). De belangrijkste doelstelling van deze first-destinations survey is om aan het einde van elk kalenderjaar een overzicht te krijgen van de vorderingen die door de afgestudeerden zijn gemaakt met betrekking tot het vinden van een werkkring of het volgen van een vervolgopleiding. In de praktijk blijkt de 'employability' van afgestudeerden ook te fungeren als een belangrijke zogeheten 'performance indicator' van universiteiten.

\section{Standaardvragenlijst}

De vragenlijst die de afgestudeerden krijgen toegezonden verschilt per universiteit, al naar gelang de informatiebehoefte bij de betreffende Careers Advisory Service. Wel bevat elke vragenlijst een aantal standaardvragen over:

1. de 'primary classification' (de eerste bestemming van afgestudeerden na hun studie);

2. indien men werk heeft: 'employer category';

3. 'type of work';

4. 'location of the employer';

5. 'qualification obtained' (behaalde graad);

6. 'class of degree where appropriate' (jaar van afstuderen).

De vragen 2, 3 en 4 worden overigens alleen gesteld wanneer er sprake is van een vaste betrekking. Ze worden gesteld in de vorm van open vragen waarin wordt geïnformeerd naar 'name of employer', 'location of post', 'employer's business at that location.' en 'job title'. De antwoorden op deze open vragen worden door elke CAS geclassificeerd aan de hand van een standaardcodeboek. De op deze wijze gecodeerde en opgeslagen informatie met betrekking tot de standaardvragenlijst wordt door vrijwel alle universiteiten op magneetband aangeleverd aan de Universities Statistical Record (USR). slechts enkele kleine instellingen schrijven de gegevens nog met de hand bij 
op de van de USR ontvangen lijsten van potentiële afstudeerders.

Naast de hiervoor genoemde standaardvragen staat het iedere CAS of universiteit vrij om daaraan nog vragen toe te voegen. Door de AGCAS wordt daarvoor een lijst met suggesties toegevoegd (zie bijlage IV).

\section{Problemen bij het onderzoek}

Hoewel de AGCAS zoveel mogelijk het gebruik van een standaardvragenlijst met een beperkt aantal vragen tracht te bevorderen, ten einde uniformiteit te bereiken, doen zich verschillende problemen voor die de vergelijkbaarheid nadelig beinvloeden. Johnes c.s.30 noemen de volgende:

1. Bij sommige universiteiten kunnen vraagtekens worden gezet bij de nauwkeurigheid van de data. ('Data are not audited').

2. Sommige universiteiten zijn meer nauwgezet bij het verzamelen van de data dan anderen. Zo zijn er opmerkelijke verschillen tussen de universiteiten in het percentage met 'onbekende bestemmingen'.

3. De methode van dataverzameling kan verschillen tussen universiteiten. Soms wordt volstaan met indirecte informatie doordat bijvoorbeeld de ouders of de afstudeervakgroep wordt gevraagd om de enquête in te vullen.

4. De periode tussen het moment van afstuderen en enquêteren loopt sterk uiteen. Doordat de afgestudeerden drie maanden na het beëindigen van het academisch jaar warin ze afstudeerden een enquête krijgen toegestuurd, is het mogelijk dat iemand die aan het begin van het academisch jaar afstudeert, ruim een jaar na het beëindigen van de studie een vragenlijst krijgt toegestuurd. Degenen die aan het einde van het academisch jaar afstuderen, krijgen daarentegen reeds binnen drie maanden een vragenlijst toegestuurd.

5. Er wordt binnen het AGCAS-onderzoek gebruik gemaakt van een eigen definitie van werkloosheid. Hierdoor doen zich problemen voor bij het vergelijken van de door de AGCAS voortgebrachte data met andere gegevensbestanden. De volgende standaarddefinities wijken af van de International Labour Organisation:

- Afgestudeerden met een tijdelijke baan worden gerekend tot de werk1ozen. Van degenen die een tijdelijke baan hebben wordt dus aangenomen dat zij gefaald hebben in het vinden van een permanente baan.

- Afgestudeerden die vanwege verdere studie niet beschikbaar zijn voor

30. Johnes, G., J. Taylor, G. Ferguson (1987), blz. 695-710. 
de arbeidsmarkt worden tot de werklozen gerekend.

- Afgestudeerden die niet zijn te achterhalen worden van het totale aantal afgestudeerden afgetrokken. Universiteiten met een groot aandeel niet achterhaalde afgestudeerden scoren daardoor relatief minder slecht met betrekking tot het percentage werklozien, omdat mag worden verwacht dat zich in de categorie onbekenden relatief veel werklozen of personen met een tijdelijke baan bevinden.

Geconstateerd kan worden dat er twee belangrijke oorzaken zijn te onderscheiden voor onnauwkeurigheid en niet-optimale vergelijkbaarheid van de resultaten van de afgestudeerden, namelijk meetproblemen en definitieproblemen.

\section{Bestemming van de resultaten}

De resultaten van de jaarlijkse enquête worden per universiteit geclassificeerd en ingevoerd op één record per afgestudeerde. De basis van elk record is al gelegd door de University Central Council on Admissions (UCCA), de Britse tegenhanger van het Nederlandse Centraal Bureau Aanmelding en Plaatsing. Deze basisinformatie omvat geslacht, studierichting en naam, adres, woonplaats.

Deze gegevens worden verzameld en tot tabellen verwerkt door de Universities Statistical Record. De USR heeft ook een belangrijk aandeel in de coördinatie en kwaliteitsbewaking. De Central Services Unit (het hoofdbureau van alle aan de universiteiten verbonden Graduate Employment Services en Careers Advisory Services) verwerkt deze gegevens in een serie statistische publikaties voor (potentiële) studenten en werkgevers. Ook diverse ministeries en onderzoeksinstellingen maken dankbaar gebruik van de resultaten. Deze publicaties zijn: Supply of university graduates; trends and predictions (bevat schattingen over de uitstroom van alle universiteiten voor de komende drie jaren), The output of UK universities by Institutions and Disciplines (geeft outputcijfers per instelling, studierichting, woonplaats en geslacht), Statistical Quarterly (geeft up-to-date informatie over de arbeidsmarkt voor academici, waaronder een vergelijking van de vacatureontwikkeling met het voorgaande jaar, onderzoek naar de aanvangsalarissen en de ontwikkeling van het aandeel van vrouwen in het hoger onderwijs).

Voor de universiteiten kunnen de gegevens eveneens van belang zijn. Dit hangt samen met de betekenis die de 'employability index' heeft als 
'performance indicator'. Deze wordt onder meer gebruikt bij de werving van nieuwe studenten door dié universiteiten die erin slagen om veel 'employable graduates' op te leiden. Overigens moeten dergelijke indices enigszins worden gerelativeerd vanwege de meet- en classificatieproblemen en de uiteenlopende inspanningen van de aan iedere universiteit verbonden CAS.

\subsubsection{Employment_survey of graduates of Ontario Universities}

Vanaf 1979 wordt in de Canadese deelstaat Ontario elke drie jaar een enquête afgenomen onder alle personen die het jaar daarvoor aan één van de 17 universiteiten of hogescholen van Ontario afstudeerden. Bij deze zogeheten Employment Survey of 1985 Graduatues of Ontario Universities ging het om in totaal 36.315 personen. Daarvan zijn uiteindelijk 19.144 bruikbare vragenlijsten ontvangen. Een respons dus van 52,7\%. Dit onderzoek wordt verricht door het Ontario Institute for Studies in Education in opdracht van The Ministry of Education en The Ministry of Colleges and Universities, die het onderzoek tevens financieren. De belangrijkste doelstelling van deze exit-enquêtes is het achterhalen van de 'post-graduate' onderwijskundige- en arbeidsmarktervaring van afgestudeerden, één jaar na hun afstuderen.

De volgende doelen en doelgroepen worden onderscheiden:

1. Verzamelen van informatie voor 'policy-makers'. Deze zijn met name geinteresseerd in 'post-secundary education' en, in samenhang met eerder verrichte surveys, de 'trends related to education'.

2. Verzamelen van statistisch materiaal voor:

- universiteiten;

- ministeries;

- het Canadese bureau voor de statistiek;

- onderzoekers.

3. Verzamelen van informatie voor personen die zich bezighouden met studieen beroepskeuzebegeleiding aan universiteiten, aan hogescholen voor toegepaste wetenschappen en techniek, en in het secundair onderwijs.

De onderzoeksopzet die hiervoor is gekozen is een schriftelijke enquête, gevolgd door achtereenvolgens een herinneringskaart, een tweede vragenlijst en een telefonische recherche met een identieke vragenlijst om de respons te vergroten.

De vragenlijst die wordt gebruikt, bestaat uit 40 vragen die voor een belangrijk deel zijn voorgecodeerd. Zij zijn verdeeld over vijf blokken met 
de volgende onderwerpen (tussen haakjes staat aangegeven wie deze vragen moeten beantwoorden):

- Zeven vragen over de opleiding die is afgerond: moment van afstuderen, soort diploma, naam van de instelling, afstudeerrichting- en onderwerp, soort afstudeerprogramma, wijze van inschrijving, werkervaring. (Allen).

- Vijf vragen over een (eventuele) vervolgopleiding: soort vervolgstudie, soort onderwijsprogramma, wijze van inschrijving, niveau en soort opleiding waar men thans mee bezig is. (Alleen diegenen die momenteel bezig zijn met een vervolgopleiding).

- Elf vragen over de huidige positie op de arbeidsmarkt: huidige activiteiten (allen); redenen voor werkloosheid, ooit naar werk gezocht sinds afstuderen?, ooit gewerkt sinds afstuderen? (voor diegenen die eerder te kennen gaven nòch werkzaam nòch werkzoekend te zijn); wijze waarop naar werk is gezocht, gewenste ondersteuning daarbij, tijdstip waarop men is begonnen met het zoeken naar werk, aantal malen contact met werkgevers, aantal sollicitatiegesprekken, aantal aanbiedingen. (Te beantwoorden door diegenen die (nog) niet werkzaam zijn).

- Dertien vragen voor diegenen die werkzaam zijn: tijdstip waarop men is begonnen met de eerste baan, belangrijkste criteria bij de keuze van deze baan, 'details of (first) job': functieaanduiding, soort werkzaamheden, sectoraanduiding, naam van de organisatie, functie bij (Rijks-)overheid; plaats, provincie of deelstaat (de voorgaande vragen met betrekking tot 'details of job' waren open. De navolgende zijn gesloten); aard van de arbeidsovereenkomst, aantal uren dat men per week werkt, aanvangsalaris, al dan niet reeds werkzaam tijdens de opleiding, na de eerste baan van baan veranderd?, zo ja: wanneer, opnieuw reeks vragen voor 'details of job', twee belangrijkste redenen om van baan te veranderen, huidige salaris, tevredenheid over onder meer de huidige werkzaamheden, karakterisering van de aansluiting van de huidige baan bij de laatstgenoten opleiding, karakterisering van de opleidingsbehoefte van de huidige baan.

- Vier vragen voor de evaluatie van beleidsdoelstellingen van het Ministry of Colleges and Universities: (hoofd-) beroep van vader, soort bedrijf, (hoofd-) beroep van moeder, soort bedrijf, hoogste niveau van onderwijs van vader en moeder, moedertaal (voor alle respondenten).

De uitvoering van deze enquête verliep in 1985 als volgt. De vragenlijsten werden centraal verzonden. De adressenbestanden werden aangeleverd door de universiteiten, met uitzondering van vier universiteiten die zelf zorgden 
voor de verzending en de herinnering. De ontvangst, de codering en de verwerking van alle vragenlijsten was in handen van het onderzoeksinstituut. Getrainde codeurs onder leiding van een tweetal supervisors classificeerden de antwoorden op de open vragen en codeerden de resultaten. De classificaties gebeurden aan de hand van het University Students Information System (USIS), de Canadian Classification and Dictionary of Occupations (CCDO) en de Standard Industrial Classification (SIC). Deze laatste twee waren in een aantal gevallen niet toereikend zodat voor sommige beroepen en sectoren speciale codes werden ontwikkeld. Voor het classificeren van vaag omschreven beroepen als 'research assistent' of 'supply teacher' werden speciale procedures ontwikkeld.

Aldus kwam voor elke universiteit een aparte database tot stand, welke per record met behulp van speciaal ontwikkelde programmatuur werd gecontroleerd op volledigheid en consistentie. De 17 verschillende databestanden werden daarna bij elkaar gevoegd zodat één grote database ontstond voor de analyses.

Het verslag van de first-destinations survey 1985 is qua opbouw en indeling identiek aan het verslag van 1982. In totaal bevat het rapport 250 pagina's, waarvan 131 tabellen. Het grootste gedeelte van de hoofdtekst bestaat uit een beschrijving en toelichting van de belangrijkste resultaten van elke tabe1. Het betreft twee- of drie-dimensionale tabellen met acht, negen of twaalf categorieën per variabele. Uit het onderzoeksverslag blijkt niet of de onderzoeksresultaten ook in de vorm van bijvoorbeeld een ruwe dataset op tape of schijf beschikbaar zijn.

\subsubsection{Vergelijking firrst-destination surveys Groot-Brittannië en Ontario}

Als belangrijkste overeenkomst tussen de first-destination surveys voor Groot-Brittannië en de Canadese deelstaat Ontario kan worden genoemd dat het in beide landen gaat om een regelmatig herhaald onderzoek onder de totale populatie afgestudeerden van universiteiten en hogescholen uit het voorgaande academische jaar. In beide onderzoeken gaat het alleen om de 'first-destinations' van de alumni. Van loopbaanonderzoeken is geen sprake.

Ten aanzien van de onderzoeksopzet kan worden geconstateerd dat er in GrootBrittannië sprake is van een decentrale opzet. Verzending, codering en verwerking van de enquêtes geschiedt door alle 52 universiteiten afzonder- 
lijk. Coördinatie hiervan is weliswaar in handen van de CSU. In Ontario gebeurt verzending, codering en verwerking van de enquêtes voornamelijk centraal.

Tevens zijn er verschillen tussen de initiërende organisaties. In GrootBrittannië zijn dit de universitaire centra voor beroepskeuze- en loopbaanbegeleiding, verenigd in de AGCAS en de CSU en daartoe in staat gesteld door een financiële bijdrage van het University Grants Committee. In Ontario is de opdrachtverlening en financiering van het onderzoeksproject afkomstig van de Ministeries van Onderwijs en van Universiteiten en Hogescholen van de deelstaat Ontario. Uitvoering is in handen van een onderzoeksinstituut. De universiteiten zelf spelen bij de voorbereiding en uitvoering nauwelijks een rol.

De onderzoekspopulaties en de tijdstippen van enquêtering komen enigszins met elkaar overeen. Beiden richten zich op een totale 'jaargang' afgestudeerden. In Groot-Brittannië gaat het dan om alle personen die in het gehele voorgaande academische jaar de universiteit met een diploma hebben verlaten. In Ontario is de tijdsspanne tussen afstuderen en enquêtering iets strikter. Daar gaat het om alle studenten die in het voorjaar van het voorgaande academische jaar afstudeerden, en acht maanden na hun afstuderen de enquêteformulieren kregen toegezonden. Wellicht heeft dit verschil te maken met een verschil in studie-opzet en diploma-uitreiking.

Ook ten aanzien van de vragenlijst doen zich verschillen voor. In GrootBrittannië worden alleen de zes basisvragen aan alle afgestudeerden voorgelegd. Het gaat dan om voornamelijk open vragen ter bepaling van de huidige werkgelegenheidssituatie, de functie, de naam en de vestigingsplaats van de werkgever, en het jaar, de richting en het niveau waarin men afstudeerde. Het staat elke universiteit vrij om hieraan nog andere items toe te voegen. In Ontario krijgen alle afgestudeerden dezelfde vragenlijst voorgelegd. Deze bevat 40 zowel open als gesloten vragen over de gevolgde opleiding, de huidige werkgelegenheidssituatie, diverse aspecten van de huidige functie en de werkgever, en enkele vragen over de sociale achtergrond.

Met betrekking tot de uitvoering van de enquête doen zich zeer belangrijke verschillen voor. In Groot-Brittannië levert elke universiteit een dataset aan de Universities Statistical Records die is belast met de verdere statistische verwerking. Het staat elke universiteit vrij om op eigen wijze deze 
gegevens te verzamelen. Het gevolg is dat er zeer uiteenlopende procedures worden gevolgd bij de verzending, de ontvangst en de codering van de vragenlijsten. Er zijn dan ook grote verschillen tussen de universiteiten onderling in het aandeel onbestelbare vragenlijsten ('non-deliverable') en het non-responspercentage. Bovendien vinden classificatie en codering op alle universiteiten afzonderlijk plaats. Zonder twijfel vormen de genoemde zaken een ernstige inbreuk op de betrouwbaarheid van de resultaten. In Ontario zijn nagenoeg alle stappen in het onderzoek in handen van hetzelfde onderzoeksteam. Bovendien worden drie achtereenvolgende pogingen ondernomen om de respons op te vijzelen. Het gevolg is dat er in de onderzoeksresultaten voor elke universiteit afzonderlijk, nauwelijks verschillen zijn waar te nemen die het gevolg zouden kunnen zijn van de opzet van het onderzoek zelf. Overigens is de respons over het geheel genomen vrij laag (53\%). Misschien voelen afgestudeerden zich minder verbonden met een voor hun onpersoonlijke landelijke organisatie dan met de universiteit waar zij hebben gestudeerd. Verzending van de vragenlijsten door de afzonderlijke universiteiten aan hun afgestudeerden kan wellicht bevorderlijk zijn voor de respons.

Ook de wijzen waarop van het onderzoek verslag wordt gedaan, lopen zeer uiteen. In Ontario blijft dit beperkt tot één lijvig rapport met een groot aantal tabellen en een schriftelijke toelichting daarop. In deze tabellen zijn alle antwoorden die zijn gegeven op open vragen gecomprimeerd in een beperkt aantal categorieën. Deze zijn er voor opleidingsrichtingen (10) enniveaus (8), beroepen (12) en werkgevers (17). Wel worden in deze tabellen veel relaties tussen categorieën weergegeven. In totaal zijn er 20 ééndimensionale tabellen en 92 tweedimensionale tabellen. Het gaat daarbij om absolute aantallen, percentages en (gewogen) gemiddelden. In het rapport staan geen aanwijzingen dat er nog andere publikaties op basis van dit onderzoek of onderzoeksverslag zijn verschenen. Ook staat niets vermeld over de beschikbaarheid van een ruwe database.

Het resultaat van de first-destinations survey in Groot-Brittannië wordt beschreven in het jaarlijks verschijnende 'University Statistics'. Dit rapport van circa 130 pagina's bestaat hoofdzakelijk uit tabellen. In een inleiding en een vijftal appendices wordt hierop een korte toelichting gegeven. De 21 tabellen beslaan tezamen 113 pagina's, hetgeen er op neer komt dat iedere tabel bijna 6 pagina's beslaat. Omdat het aantal variabelen dat in deze 21 tabellen aan de orde komt, beperkt is, is elke tabel zeer gedetailleerd. Zo worden bijvoorbeeld de studierichtingen in 16 hoofdgroepen 
verdeeld. Deze zijn weer opgesplitst in 112 subgroepen. Dergelijke indelingen zijn er ook voor de bedrijfstak waarin men werkzaam is en het soort werkzaamheden dat men verricht. Voor al deze hoofd-en subgroepen zijn de verdelingen aangegeven. Doorgaans bevatten deze alleen de absolute aantallen. In een aantal tabellen worden de totalen en subtotalen gepercenteerd. In slechts één tabel worden de afgestudeerden per universiteit afgezet tegen de eerste bestemming na de opleiding. Vergelijking met onderzoeksresultaten van voorgaande jaren vindt nauwelijks plaats. In tegenstelling tot het meer beschrijvende en beleidsgerichte onderzoeksverslag van de first-destinations survey uit Ontario, vormt dit tabellenboek de basis voor zeer uiteenlopende publikaties voor diverse doelgroepen.

Over een belangrijk aspect dat in deze vergelijking zeker betrokken had moeten worden valt helaas weinig te zeggen. Het gaat om een vergelijking van de resultaten met de kosten van beide onderzoeken. Vermoedelijk is de Canadese onderzoeksopzet efficiënter. In ieder geval is ze nauwgezetter, waardoor ongetwijfeld hogere kosten worden gemaakt. Gedacht kan worden aan de kosten die ontstaan door het selecteren en verzenden van herinneringskaarten, tweede vragenlijsten en de telefonische recherche om de respons te vergroten. Ook de nauwgezette procedures die worden gevolgd bij het coderen zullen een kostenopdrijvende werking hebben. Aan de andere kant treden hierdoor efficiëncy-effecten op doordat de resultaten nauwkeuriger zijn en minder correcties behoeven.

\subsection{Conclusies}

In de voorgaande paragraaf is een groot aantal mogelijkheden geschetst voor de organisatie en de methoden en instrumenten voor onderzoek naar de arbeidsmarktpositie van afgestudeerden. Deze organisatie- en onderzoeksaspecten moeten worden bezien in samenhang met het gewenste datamateriaal en de criteria die daarvoor in paragraaf 2.5. zijn beschreven.

Derhalve kan op dit moment het volgende worden geconcludeerd:

- Het onderzoek onder afgestudeerde academici naar hun positie op de arbeidsmarkt staat nog in de kinderschoenen. Hoewel er van verschillende zijden en om uiteenlopende redenen een toenemende belangstelling bestaat voor dergelijk onderzoek, is de vergelijkbaarheid van de onderzoeksresultaten tot dusverre nog gering. De belangrijkste reden daarvoor is tweeërlei. Enerzijds is de vraagstelling nooit identiek en wijkt deze meestal af van de internationale standaarddefinities en classificaties. Anderzijds is 
de wijze waarop de antwoorden zijn gecategoriseerd zelden vergelijkbaar. De onderzoeksresultaten zijn dan ook vrijwel zonder uitzondering niet te gebruiken voor het in paragraaf 2.3. genoemde ROA-informatiesysteem voor onderwijs en arbeidsmarkt 31 op basis waarvan onderlinge vergelijkingen wel mogelijk zijn.

- Een ander probleem wordt gevormd door de beperkte representativiteit van veel onderzoeken en de geringe dekkingsgraad van de uiteindelijk bereikte populatie ten opzichte van de totale of potentiële populatie. De beperkte organisatiegraad speelt hierbij een doorslaggevende rol.

- Van groot belang is de mate waarin een organisatie haar leden aan zich weet te binden en haar adressenbestand actueel weet te houden. Organisaties die regelmatig onderzoek verrichten onder hun leden, en mede met het oog daarop adressen bijhouden, slagen er veel beter in een hogere respons te bereiken dan bij een eenmalig onderzoek doorgaans het geval is.

- Voor zover op dit moment bekend, worden er noch in het buitenland noch in ons eigen land op grote schaal loopbaanonderzoeken gehouden. De bekende buitenlandse onderzoeken beperken zich tot groots opgezette first-destinations surveys: een eenmalige peiling naar de arbeidsmarktbestemming, circa één jaar na het afronden van de universitaire opleiding. Ook in eigen land is van loopbaanonderzoek in feite geen sprake. Weliswaar verricht de Stichting Maatschappelijke Plaats Wageningse Afgestudeerden (MPW) iedere vijf jaar een survey onder alle afgestudeerden van één universiteit, maar een beeld van de individuele loopbanen wordt daarmee nog niet verkregen.

- Géén van de aangetroffen onderzoeken heeft een prognostisch karakter. Overigens lenen de onderzoeksresultaten zich daar ook niet voor.

- Er wordt weinig gebruik gemaakt van steekproeven. Vrijwel iedere organisatie streeft naar een zo volledig mogelijk beeld van de totale groep afgestudeerden. Enkele uitzonderingen daargelaten betreft het dan één of meerdere jaargangen of generaties afgestudeerden. Ook verbijzonderingen naar studierichting komen voor. Eén faculteit heeft ervoor gekozen om het kalenderjaar als segmentatiecriterium te kiezen.

- Zowel voor Groot-Brittannië als voor Ontario geldt dat voor de definiëring en classificatie gebruik is gemaakt van standaarddefinities en standaardclassificaties. In Ontario bleek dat een aantal categorieën uit de standaardclassificatie niet verfijnd genoeg was. Daar werd dan een extra verfijning in aangebracht. Overigens heeft in ons land MPW hetzelfde gedaan

31. ROA-R-1989/1. 
voor de categorie 'openbaar bestuur' in de Standaard Bedrijfs Indeling.

- De gewenste eenheid en vergelijkbaarheid van de onderzoeksresultaten zijn gebaat bij een centrale opzet, coördinatie, analyse en rapportage. Bepaalde aspecten van de uitvoering zouden op decentraal niveau kunnen plaatsvinden. Gedacht kan worden aan adressering, verzending, ontvangst en rappellering. Ook de verwerking (coderen en invoeren) van de resultaten zou op decentraal niveau kunnen gebeuren. Voor zowel de feedback van de onderzoeksresultaten naar de onderzoeksgroep als de vertaling en doorwerking ervan in beleidsdoelstellingen, is de medewerking van het decentraal niveau bijkans onontbeerlijk.

- De eenheid en vergelijkbaarheid zijn vervolgens gebaat bij een stelsel van gesloten vragen en antwoorden. Ter contrôle op in ieder geval de vragen naar beroep en bedrijfstak waarin men werkzaam is, dienen tevens open vragen te worden opgenomen. De vragen ter vaststelling van het hoogstbehaalde onderwijsdiploma (niveau en richting) zouden zowel een open als een gesloten karakter kunnen hebben. Aan beide opties zijn voor- en nadelen verbonden.

- Bij nagenoeg alle onderzoeken is in eerste instantie gebruik gemaakt van een schriftelijke enquête. Om de respons te vergroten wordt, in tweede instantie, dikwijls gebruik gemaakt van een telefonische recherche en enquêtering. Met betrekking tot de gebruikte adressenbestanden kan worden opgemerkt dat slechts één universiteit en enkele faculteiten op systematische wijze adressen van afgestudeerden bijhouden. In de meeste gevallen wordt dit ad-hoc gedaan. Universiteiten en faculteiten laten dit doorgaans over aan verenigingen van afgestudeerden.

- De rijksoverheid treedt in een aantal gevallen op als (mede)-financier van first-destinations surveys en 'loopbaanonderzoeken'. Het verdient aanbeveling dat voortaan als voorwaarde voor subsidiëring wordt gesteld dat gebruik moet worden gemaakt van standaarddefinities en -classificaties. 


\section{STANDAARDVRAGENLIJSTEN VOOR DE AANBODZIJDE}

\subsection{Inleiding}

Om een goed beeld te krijgen van de arbeidsmarktervaringen van afgestudeerde gezondheidswetenschappers moet gebruik worden gemaakt van een regelmatig te houden enquête onder afgestudeerden. Daarbij wordt gekozen voor een longitudinale opzet teneinde veranderingen in loopbanen te kunnen vaststellen.

Voor deze enquête zijn twee vragenlijsten ontwikkeld en getest. Dit zijn de zogeheten 'basisvragenkaart' en de 'jaarkaart'. De basisvragenkaart wordt aan alle afgestudeerden circa één jaar na het voltooien van de studie toegezonden. De jaarkaart wordt vervolgens jaarlijks in de daarop volgende jaren verstuurd. De jaarkaart is een verkorte versie van de basisvragenkaart. In de laatstgenoemde kaart is nog een aantal vragen opgenomen die voornamelijk betrekking hebben op de gevolgde studie. Beide vragenlijsten zijn voorzien van een toelichting op de vragen en antwoordmogelijkheden met bijbehorende codes. Aan de geënquêteerden wordt gevraagd om de op hen van toepassing zijnde codes op de vragenkaart aan te geven. Op de kaarten staat al een aantal antwoorden voorgedrukt. Op de basisvragenkaart zijn dat gegevens die door het opleidingsinstituut zijn verstrekt. Op de jaarkaart staan de antwoorden die in het voorgaande jaar zijn gegeven. Aan de geënquêteerden wordt verzocht om onvolledige of onjuist geworden gegevens aan te vullen of te corrigeren.

Het ontwikkelen en het testen van deze vragenlijsten komen in de hierna volgende paragrafen aan de orde. In paragraaf 5.2 zal worden ingegaan op de constructie van de beide vragenlijsten. Daarbij zullen inhoudelijke randvoorwaarden aan de orde komen. In paragraaf 5.3 wordt het testen van de vragenlijsten besproken. Aan de hand van enkele criteria is aan een aantal proefpersonen gevraagd de vragenlijsten in te vullen. Deze zijn op grond hiervan op een aantal plaatsen bijgesteld. De bijgestelde vragenlijsten zijn als Bijlage I en II opgenomen.

Het is overigens mogelijk om de in dit hoofdstuk voorgestelde jaarlijkse bevraging periodiek, bijvoorbeeld vijfjaarlijks, aan te vullen met vragen over de beroepsmobiliteit, het verdere verloop van de beroepscarriere en eventuele andere thema's betreffende de aansluiting tussen onderwijs en arbeidsmarkt, die men in deze vijfjaarlijkse bevraging aan de orde wil 
stellen.

\subsection{De constructie van de vragenlijsten}

\subsubsection{Werkwij $\underline{j} \underline{z}$}

Bij de constructie van de vragenlijsten gold als uitgangspunt dat hiermee data voortgebracht zouden moeten worden die met andere gegevensbronnen zijn te vergelijken. Dit impliceert dat deze data op een methodisch verantwoorde wijze zijn verzameld en aansluiten op (inter-)nationaal gehanteerde definities van begrippen als werkloosheid en werkgelegenheid en classificaties van bijvoorbeeld opleiding, beroep en bedrijfstak.

Daarnaast zouden met behulp van deze vragenlijsten gegevens moeten worden voortgebracht waarmee analyses en prognoses kunnen worden verricht op het niveau van studierichtingen.

Om aan de bovenstaande vereisten tegemoet te kunnen komen is een aantal veelgebruikte vragenlijsten geanalyseerd. Genoemd kunnen worden de vragenlijst van de Enquête Beroepsbevolking (EBB) van het CBS, waaraan veel vragen en antwoorden zijn ontleend, en de vragenlijsten die worden gebruikt bij de loopbaanonderzoeken van de Stichting Maatschappelijke Plaats Wageningse Afgestudeerden. Het gebruik van basisvragen- en jaarkaarten en de vormgeving ervan zijn daarvan afkomstig. Voor de samenstelling van de classificaties is gebruik gemaakt van de standaardindelingen van het CBS en van de onderzoeksresultaten van Kramer en Schreurs (1988).

\subsubsection{De inhoud_en_samenstellling van de vragenl ij}

In paragraaf 2.4 is reeds ingegaan op de benodigde informatie. Op grond daarvan, en na bestudering van de eerder genoemde vragenlijsten, is besloten tot de volgende opbouw van zowel de basisvragenkaart als de jaarkaart:

a. persoonsgegevens;

b. opleidingsgegevens (alleen in de basiskaart);

c. huidige arbeidsmarktsituatie;

d. kenmerken van beroep en functie;

e. organisatiekenmerken;

f. activiteiten (indien niet werkzaam) en aanvullende opleidingen. 
ad. a: Hier worden achtereenvolgens naam, voorletters, adres, postcode, woonplaats, land en telefoonnummer gevraagd. Het spreekt vanzelf dat de beschikbaarheid en de juistheid van deze gegevens een bepalende en noodzakelijke voorwaarde vormt voor het welslagen van onderzoek onder afgestudeerden. In hoofdstuk $7 \mathrm{zal}$ daarom verder worden ingegaan op de organisatie van het verzamelen en het actualiseren van persoonsgegevens. Bij de evaluatie van de vragenlijsten zal ook op deze facetten worden ingegaan.

ad. b: In de basisvragenkaart is, in aansluiting op de hiervoorgenoemde persoonsgegevens, een aantal vragen opgenomen over de (op dat moment onveranderlijk geworden: 'irreversibele') persoonsgegevens, zoals geboortejaar, geslacht, vooropleiding, de reeds aanwezige werkervaring op het moment van afstuderen en de belangrijkste bezigheden, per maand, tussen het moment van afstuderen en het moment van enquêteren. Verder bevat dit vragenblok vragen over de gevolgde studie- en afstudeerrichting(-en) en de data van aanvang en voltooiing van de studie. Al deze gegevens zijn, met uitzondering van de vraag naar de bezigheden na het afstuderen, eveneens bekend bij de onderwijsadministratie van de faculteit waarin men afstudeerde. De vragen over de voltooide studie- en afstudeerrichting zijn open. Codering van de antwoorden zal gebeuren aan de hand van een indeling die is gebaseerd op de Standaard Onderwijs Indeling (SOI) van het CBS. Uiteraard zal onderscheid worden gemaakt tussen de verschillende afstudeerrichtingen, hetgeen binnen de SOI niet wordt gedaan. Daarbij kan worden gedacht aan het toevoegen van een zesde positie aan de SOI-codes. Het valt te verwachten dat met name de codering van nieuwe- en vrije afstudeerrichtingen problemen zal geven. Bij het testen zal hieraan aandacht worden geschonken.

ad. c: De huidige arbeidsmarktsituatie verwijst naar de belangrijkste dagelijkse werkzaamheden die door de respondent worden verricht. Dit om vast te stellen of iemand behoort tot de werkzame beroepsbevolking zoals die door de International Labour Organisation wordt gedefinieerd. De hiervoor gestelde vraag is rechtstreeks overgenomen uit de vragenijist voor de Enquête Beroepsbevolking (EBB) van het CBS. (In zoverre, dat in de EBB gevraagd wordt of iemand 1 of meer uren in loondienst werkzaam is. In onze vragenlijsten is dat niet het geval). In de evaluatie zal met name aandacht moeten worden geschonken aan de relevantie van de antwoordcategorieën.

ad. d: In het vragenblok over de kenmerken van beroep en functie wordt gevraagd of men in het afgelopen jaar van functie of werkgever is veranderd, 
op welke wijze men de huidige functie heeft verkregen, wat de aard en de tijdsduur van de huidige aanstelling is, en tot welke (voorgecodeerde) beroepsgroepen men behoort. Ter contrôle hierop is tevens een open vraag opgenomen over de functienaam. De bijgevoegde lijst met benamingen van de beroepsgroepen met de bijbehorende codes is afgeleid uit de beroepenclassificatie die door het CBS wordt gehanteerd.

Tot dit vragenblok behoren tevens vragen over de mate waarin men leiding moet geven en de hoogte van het bruto jaarinkomen. Met name voor de laatste vraag geldt dat in de testfase goed moet worden nagegaan of de vraagstelling voldoende duidelijk is.

ad. e: Tot het vragenblok over de kenmerken van de organisatie waarbij men werkzaam is, behoren vragen over de branche, de totale personeelsomvang, het soort produkt of dienst van de organisatie, en de postcode en het land van de werkgever. De respondenten wordt gevraagd om de branche-code aan te geven. Hiertoe is een lijst van bedrijfsgroepen opgesteld met de bijbehorende SBI-codes (Standaard BedrijfsIndeling), die door het CBS worden gehanteerd.

In de testfase zou met name bij dit vragenblok nader stil moeten worden gestaan. Opname van een open vraag over het adres en het organisatie onderdeel waarbij men werkzaam is, dient te worden overwogen. Dit met het oog op het opbouwen van een adressenbestand van werkgevers. Tevens moet worden nagegaan of iedere respondent de vraagstelling betreffende het belangrijkste produkt of dienst van de organisatie op dezelfde wijze interpreteert.

ad. $f$ : Aan de afgestudeerden wordt gevraagd of en zo ja op welke wijze men in de afgelopen vier weken naar werk heeft gezocht, en of men daar dan binnen twee weken aan zou kunnen beginnen. Deze vragen zijn opgenomen om vast te kunnen stellen of men overeenkomstig de ILO-definitie nog als werkzoekende, en dus behorend tot de beroepsbevolking, kan worden aangemerkt. Ook zou deze vraag gegevens moeten opleveren (tesamen met het antwoord op de vraag over functieverwerving) over het zoekgedrag op de arbeidsmarkt. De hier geboden antwoordmogelijkheden zijn grotendeels afkomstig uit de eerder genoemde EBB. Bovendien wordt gevraagd of men in het afgelopen jaar een cursus of opleiding heeft gevolgd en zo ja wat de aard en richting daarvan was. Naast de inhoud van de vragenlijst zijn ook de visuele presentatie (layout), de introductie middels een begeleidende brief, en de 'routing' van de vragen van belang. 


\subsection{Het testen van de vragenlijst}

Om de door ons ontwikkelde basisvragenkaart te testen, is een beperkte proefenquête verricht. Daarvoor zijn van het Bureau Onderwijs van de Faculteit der Gezondheidswetenschappen van iedere afstudeerrichting gegevens gevraagd van twee studenten die tussen april en juni 1988 afstudeerden. Om de jaarkaart te testen zijn uit het adressenbestand van het eerder verrichte loopbaanonderzoek (Kramer/Schreurs, 1988) van de afstudeerrichtingen Beleid en Beheer, Gezondheidsvoorlichting en -opvoeding en Verplegingswetenschap de adressen verkregen van twee afgestudeerden uit de periode april-juni 1985 en twee afgestudeerden uit de periode april-juni 1986. Gegevens werden verkregen over in totaal tien recent afgestudeerden en twaalf personen die enkele jaren geleden hun studie voltooiden. Van deze afgestudeerden is een groot aantal gegevens verkregen waarmee, uiteraard vertrouwelijk, een vergelijking kon worden gemaakt met de resultaten van de proefenquêtes. Aan deze personen is een brief verzonden met, bij wijze van vooraankondiging, het verzoek om mee te werken aan het testen van de ontwikkelde vragenlijsten. Een week na verzending van deze brief werd telefonisch contact opgenomen om de reactie van de afgestudeerde te vernemen. Was deze bereid tot deelname, dan werd een concept-vragenlijst met daarbij een speciaal voor dit doel ontwikkeld evaluatieformulier toegezonden. Dit evaluatieformulier is opgenomen in BIJLAGE III.

Van de twaalf reeds langer afgestudeerden konden acht personen worden achterhaald. Hiervan stuurden zeven personen de ingevulde jaarkaart met bijbehorend evaluatieformulier tijdig retour. Van de tien recent afgestudeerden, waarvan naam en adres was verkregen, konden acht personen worden achterhaald. Hiervan stuurden vijf personen de ingevulde basisvragenkaart met bijbehorend evaluatieformulier tijdig retour. Dit betekent dat de deelname van de reeds langer afgestudeerden aan de proefenquête relatief groter was dan van de recent afgestudeerden.

De evaluatie gebeurde in twee ronden. Eerst werden de ingevulde evaluatieformulieren doorgenomen; daarna de ingevulde jaar- en basisvragenkaarten. Daarbij lag de nadruk vooral op de consistentie van de gegeven antwoorden.

\subsubsection{Bijjstell ingen op grond van de evaluatieformul ieren}

In de twaalf ontvangen evaluatieformulieren werden enerzijds inhoudelijke 
kanttekeningen geplaatst en anderzijds tekstuele en formele opmerkingen. De belangrijkste bevindingen worden hieronder weergegeven.

Met betrekking tot de begeleidende brief met instrukties blijkt dat de doelstellingen van het onderzoek geheel duidelijk zijn voor alle reeds langer afgestudeerden. Tevens zijn zij van mening dat deze een jaarlijkse enquête zeer zeker rechtvaardigen. Dit ligt iets genuanceerder bij recent afgestudeerden. Enkelen willen duidelijker worden geïnformeerd (in de begeleidende brief) over het gebruik van de resultaten. Tevens staan zij gematigd positief tegenover de doelstellingen. Enkele instrukties bleken niet duidelijk genoeg. Men vond geen enkele instruktie overbodig.

De reeds langer afgestudeerden waren circa 15 minuten bezig met het invullen van de jaarkaart. Het invullen van de basisvragenkaart bleek iets meer tijd in beslag te nemen: gemiddeld 20 minuten. De volgorde van de vragen werd logisch gevonden. Geen van de respondenten was van mening dat de vragenlijst items bevat die dusdanig privacygevoelig zijn dat men vragen daarover niet wenste te beantwoorden. In de in de proefenquête gebruikte vragenlijsten werd gevraagd naar de postcode van de werkgever. Twee personen vroegen zich af waarom naar de postcode van de werkgever werd gevraagd. Wellicht was niet duidelijk dat het een indicatie voor geografische spreiding betrof want geen van de proefpersonen zou er bezwaar tegen hebben om het 'werkadres' te verstrekken. In de in de proefenquête gebruikte vragenlijsten werd gevraagd naar eventuele verandering van functie en van werkgever in het afgelopen jaar. Enkele respondenten vroegen zich af of de formulering 'het afgelopen jaar' betrekking had op het kalenderjaar of op het studiejaar. Voor de duidelijkheid is in de bijgestelde vragenlijsten gekozen voor 'de afgelopen twaalf maanden'. Niettemin blijft een belangrijke vraag of de gegevens per studiejaar/generatie worden verzameld, waardoor vergelijking met studentenaantallen mogelijk is, of dat de enquêteresultaten per kalenderjaar worden opgeslagen waardoor vergelijking met nationale arbeidsmarktgegevens mogelijk wordt.

Met betrekking tot de vormgeving van de in de proefenquête gebruikte vragenlijsten was de helft zeer tevreden. Drie personen waren van mening dat dit beter moest. Zij hebben alle betrekking op de basisvragenkaart. Deze is dan ook bijgesteld. 


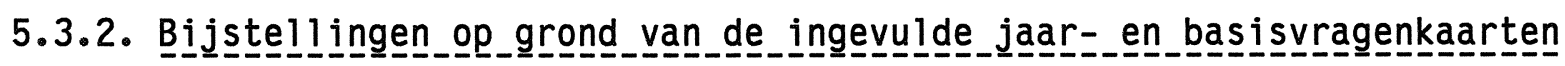

De belangrijkste onjuistheden die zich hier voordeden betroffen het ontbreken van een instruktie, in de in de proefenquête gebruikte vragenlijsten, waardoor bijna iedereen de vragen over aanvullende opleidingen of cursussen niet beantwoordde, terwijl deze vragen door iedereen moesten worden ingevuld. De in de bijlagen opgenomen vragenlijsten zijn ook op dit punt bijgesteld.

Een zeer belangrijk punt dat naar voren kwam betreft een vergelijking van de door de respondenten gekozen beroepencode met de door hen gegeven functienaam. Codering door de onderzoeker leidde in een aantal gevallen tot een andere beroepencode dan door de respondent was gekozen. Zo had een respondente, werkzaam als docente verpleegkunde (code 1315), gekozen voor code 0715 welke hoort bij het beroep docent/verpleegkundige. Een contrôle op de door de respondent gekozen codering dient dus in alle gevallen plaats te vinden. Overigens wordt dit wel aanzienlijk vereenvoudigd met de door de respondent gekozen codering als uitgangspunt.

Met de keuze van de branchecode door de respondenten deden zich in het proefonderzoek minder problemen voor. Niettemin mag worden verwacht dat zich met name bij de semi-overheidsinstanties een keuzeprobleem zal voordoen. Dat is eveneens het geval wanneer men formeel in dienst is van een overheidsinstantie maar werkt bij een instelling voor maatschappelijke dienstverlening of een sociaal-culturele of culturele instelling. Wat in deze gevallen de juiste codering dient te zijn is niet goed vast te stellen aangezien een contrôlemogelijkheid ontbreekt. Deze zou direkt voorhanden zijn als naar het 'werkadres' wordt gevraagd. Gezien de antwoorden op de desbetreffende vragen in het evaluatieformulier zijn daartegen weinig bezwaren te verwachten. Bovendien biedt het adressenbestand dat op deze wijze ontstaat diverse gebruiksmogelijkheden voor een faculteit ${ }^{32}$. Een derde voordeel is de mogelijkheid om wijzigingen in het woonadres via het werkadres te achterhalen. Tot slot kan op deze wijze een bestand worden verkregen voor onderzoek onder werkgevers van gezondheidswetenschappers. Hierop zal in het volgende hoofdstuk worden ingegaan.

32. Diverse verenigingen van afgestudeerden in Nederland geven almanaks uit waarin zowel privé- als werkadressen zijn opgenomen. 


\section{AANZET TOT HET IN KAART BRENGEN VAN DE VRAAGZIJDE}

\subsection{Inleiding}

Om inzicht te krijgen in de arbeidsmarktperspectieven van afgestudeerde gezondheidswetenschappers en in de aansluiting van de opleiding op de beroepsuitoefening kan niet worden volstaan met het verzamelen van gegevens bij afgestudeerden. De langs die weg verkregen informatie dient te worden aangevuld met gegevens over de huidige en de te verwachten vraag naar afgestudeerde gezondheidswetenschappers, de mate waarin zij concurrentie ondervinden van andere categorieën opgeleiden, de arbeidsvoorwaarden en carrièremogelijkheden van werkzame gezondheidswetenschappers, en de veranderingen in hun beroepsprofielen. Informatie hierover kan worden verkregen van werkgevers. In dit hoofdstuk wordt een aanzet gegeven voor periodiek onderzoek onder werkgevers waarmee informatie over de genoemde onderwerpen kan worden gegenereerd, die aansluit op de informatie die wordt verkregen door het onderzoek onder de afgestudeerden (zie hoofdstuk 5).

In paragraaf 6.2. wordt nader ingegaan op de benodigde informatie. Vervolgens komt in paragraaf 6.3. aan de orde welke informatie over werkgevers in de gezondheidszorg en aanverwante organisaties reeds (in potentie) voorhanden is. Daarbij wordt ingegaan op enkele onderzoeken en statistieken die in hoofdstuk 2 al ter sprake kwamen. In paragraaf 6.4. komt de samenstelling van het werkgeverspanel en de keuze tussen de verschillende onderzoeksmethoden ter sprake. In paragraaf 6.5. zal een conceptvragenlijst worden ontwikkeld waarmee werkgevers van gezondheidswetenschappers jaarlijks kunnen worden benaderd. In paragraaf 6.6. wordt verslag gedaan van het vooronderzoek dat met de concept-vragenlijst is verricht onder vijf werkgevers van afgestudeerden in de gezondheidswetenschappen. Op grond hiervan worden conclusies getrokken die van belang zijn voor de verdere ontwikkeling van de instrumenten die nodig zijn om de vraagzijde in kaart te brengen.

\subsection{De benodigde informatie over de vraagzijde}

Ten aanzien van de bij werkgevers te verzamelen werkgelegenheidgegevens kan onderscheid worden gemaakt tussen twee soorten gegevens. Het gaat om enerzijds gegevens die op de korte termijn fluctueren en anderzijds gegevens die slechts op de middellange termijn aan veranderingen onderhevig zijn. 
Gegevens met betrekking tot de werkgelegenheid die aan fluctuaties op de korte termijn onderhevig zijn, bijvoorbeeld als gevolg van de conjuncturele ontwikkeling, betreffen:

- de omvang en samenstelling van het personeelsbestand van (potentiële) werkgevers naar leeftijd, soort aanstelling, functie en opleiding;

- de verwachte- cq. benodigde personeelssamenstelling op de korte termijn (vacatures);

- de arbeidsvoorwaarden.

De informatie over de bovengenoemde aspecten zou uiteindelijk beschikbaar moeten zijn in de vorm van een dataset of een datamatrix, ofwel in de vorm van kengetallen en indicatoren. De belangrijkste eisen die aan de gegevens moeten worden gesteld zijn consistentie, representativiteit en vergelijkbaarheid. Of in de behoefte aan dit soort gegevens kan worden voorzien is vooral afhankelijk van de wijze waarop en de mate waarin werkgevers personeelsgegevens registreren en bereid zijn om deze voor onderzoeksdoeleinden ter beschikking te stellen. Dit is aan de orde gekomen in een gehouden vooronderzoek. Een tweede belangrijke vraag die in het gehouden vooronderzoek nader is bekeken betreft de wijze waarop de benodigde (en beschikbare) gegevens het beste kunnen worden verzameld. Vooralsnog wordt gedacht aan het ontwikkelen van een korte, sterk gestruktureerde vragenlijst waarmee vooral kwantitatieve gegevens worden verkregen en die jaarlijks onder een aantal werkgevers moet worden afgenomen. Overigens is ook een punt van (voor)onderzoek geweest of dit regelmatig terugkerende onderzoek één keer per jaar of om de paar jaar moet worden verricht.

Een aantal kenmerken met betrekking tot de werkgelegenheid wordt vooral door strukturele ontwikkelingen bepaald, waardoor de veranderingen in deze kenmerken zich voltrekken over een tijdspanne van meerdere jaren. Het gaat om de volgende kenmerken:

- de beroepsprofielen in de gezondheidszorg en de veranderingen daarin;

- de verwachte- cq. benodigde personeelssamenstelling op de middellange termijn;

- de substitutieverhoudingen tussen de verschillende categorieën opgeleiden;

- de verdringing van lager opgeleiden door hoger opgeleiden;

- het wervings- en selectiebeleid van werkgevers in de gezondheidszorg en aanverwante organisaties;

- het loopbaan- en scholingsbeleid van deze werkgevers. 
In dit hoofdstuk zal slechts summier op het verzamelen van deze structurele gegevens worden ingegaan. Er zal hoofdzakelijk aandacht worden besteed aan de korte-termijngegevens die elk jaar zouden moeten worden verzameld.

De onderwerpen voor het jaarlijkse onderzoek worden in paragraaf 6.5. uitgewerkt en geoperationaliseerd. Eerst wordt echter stilgestaan bij de vraag welke informatie reeds (in potentie) voorhanden is.

\subsection{Beschikbare informatie over werkgevers en werknemers in de gezond- heidszorg}

Het verdient aanbeveling om stil te staan bij de vraag welke informatie over werkgevers en werknemers in de gezondheidszorg reeds voorhanden is. Mocht bepaalde informatie in ruime mate beschikbaar zijn, dan kunnen bij de gegevensverzameling bepaalde vragen immers achterwege worden gelaten of kan in de te hanteren vragenlijst worden aangesloten bij de reeds beschikbare gegevens.

In hoofdstuk 2 is het Nederlands Ziekenhuis Instituut (NZI) genoemd als een belangrijke gegevensverzamelende instantie in de gezondheidszorg. Het NZI neemt de jaarlijkse Enquête Personeelssterkte Intramurale Gezondheidszorg af onder alle wettelijk erkende instellingen voor intramurale gezondheidszorg. Dit gebeurt ten behoeve van de gezondheidsstatistieken van het CBS en de geneeskundige hoofdinspecties van het Ministerie van WVC. Met de hiervoor gehanteerde vragenlijst wordt zeer gedetailleerde informatie verkregen over onder meer de personele samenstelling, het ziekteverzuim en het personeelsverloop bij instellingen in de intramurale gezondheidszorg. Toch zijn er enkele beperkingen. De belangrijkste is wel dat de vragenlijst één niet nader gespecificeerde verzamelcategorie kent voor de 'Medisch- en Sociaal Wetenschappelijke Staf'. Het is aannemelijk dat met name in deze categorie relatief veel gezondheidswetenschappers terechtkomen 33 . Een tweede bezwaar is dat de aanvullende vragen in de vragenlijst alleen betrekking hebben op de uitgeoefende beroepen. De door de beroepsbeoefenaren gevolgde opleiding is (nog) niet te achterhalen. Overigens worden door het NZI door middel van andere onderzoeken wel gegevens verzameld over onder meer de arbeidsvoorwaarden en de interne opleidingen. Op grond van het voorgaande

33. Van 118 werkzame afgestudeerden uit het onderzoeksbestand van Kramer/Schreurs (1988) zijn 26 personen werkzaam in een instelling voor intramurale zorg 
verdient het aanbeveling om in overleg te treden met het NZI om de mogelijkheden na te gaan van een aanpassing van de gehanteerde vragenlijst.

Een tweede bron van informatie over de (potentiële) werkgevers van gezondheidswetenschappers bestaat uit de af te nemen enquêtes onder afgestudeerden (zie hoofdstuk 5). De daarvoor ontwikkelde vragenlijst bevat onder meer vragen over de plaats van vestiging van de organisatie waarin men werkzaam is, de personele omvang, de wijze van recrutering, de bedrijfstak en de belangrijkste dienst of het belangrijkste produkt van de betreffende organisatie. Tevens wordt gevraagd naar de naam en het adres van deze werkbiedende organisaties. Op deze wijze ontstaat een belangrijk potentieel relatiebestand voor de desbetreffende faculteit.

Het voorgaande resumerend, moet worden vastgesteld dat de in paragraaf 6.2. genoemde gegevens van werkgevers in de gezondheidszorg vooralsnog ontbreken. Gegevens hierover zullen door middel van periodiek onderzoek moeten worden verzameld. In de volgende paragraaf wordt ingegaan op de onderzoeksmethoden die daarbij kunnen worden gebruikt.

\subsection{De te hanteren onderzoeksmethoden en de onderzoekspopulatie}

Met een jaarlijks onderzoek onder werkgevers dient kwantitatieve informatie te worden verkregen over de gegevens die op een termijn van een jaar sterk kunnen veranderen. Dit zijn:

- de omvang en samenstelling van het personeelsbestand van (potentiële) werkgevers naar functie en per functie naar opleiding (niveau, studie- en afstudeerrichting) en leeftijd;

- de verwachte c.q. benodigde personeelssamenstelling op de korte termijn (vacatures).

Voor het jaarlijkse onderzoek kan gebruik worden gemaakt van gegevens uit jaarverslagen van bedrijven en instellingen in de gezondheidszorg. Voorzover dat onvoldoende informatie oplevert kan gebruik worden gemaakt van enquêtes bij personeelsfunctionarissen. Bij enquêtering van een groot aantal bedrijven en instellingen ligt een schriftelijke bevraging om praktische redenen voor de hand. Het voordeel hiervan is dat de benodigde informatie op uniforme wijze en relatief goedkoop wordt geregistreerd en snel kan worden verwerkt. Welke mogelijkheden en voorwaarden hieraan verbonden zijn, is onderwerp geweest van een vooronderzoek waarover in paragraaf 6.6 verslag wordt 
gedaan.

De resultaten van het jaarlijkse onderzoek onder werkgevers zouden kunnen worden aangevuld met de resultaten van een uit te voeren advertentieanalyse. Hierbij worden de externe vacatures voor gezondheidswetenschappers, die verschijnen in de grootste dag- en weekbladen en relevante vakbladen, doorlopend gëinventariseerd en gerubriceerd naar een aantal kenmerken. Op deze wijze onstaat een actuele database waarin per vacature informatie is opgenomen met betrekking tot:

- de naam van de bedrijfstak volgens de SBI waartoe de organisatie kan worden gerekend die de desbetreffende vacature aanbiedt;

- de personeelsgrootte van de (desbetreffende vestiging van de) organisatie;

- de inhoud van de te vervullen functie (functietaken);

- de functie-eisen, waaronder de opleiding (naar studie- en afstudeerrichting en niveau) en de eventueel vereiste werkervaring;

- de arbeidsvoorwaarden, waaronder het minimum- en maximumsalaris, de duur van de aanstelling en de werktijdfaktor.

In kwantitatief opzicht is een advertentie-analyse echter van beperkte waarde aangezien personeelsadvertenties alleen een (beperkt) beeld geven van de externe vacatures, dus niet van de vacatures die intern worden opgevuld. Ook blijkt de voor een vacature gevraagde opleiding vaak te verschillen van de feitelijk gevolgde opleiding van de uiteindelijk aangestelde persoon.

Om de in paragraaf 6.2 genoemde strukturele werkgelegenheidsgegevens te kunnen verzamelen, wordt voorgesteld om de jaarlijkse vragenlijst meerjaarlijks aan te vullen met een aantal extra vragen over:

- de verwachte c.q. benodigde personeelsomvang en -samensteliing op de middellange termijn;

- het wervings- en selectiebeleid, in het bijzonder de substitutieverhoudingen tussen de verschillende categorieën opgeleiden;

- het loopbaan- en scholingsbeleid.

Voor het bepalen van de middellange-termijnontwikkeling in de omvang en de samenstelling van de vraag naar personeel zijn verschillende methoden mogelijk, die al dan niet in combinatie kunnen worden gebruikt ${ }^{34}$. Naast

34. In paragraaf 3.3. is geconcludeerd dat met behulp van de bestaande statistieken, modellen en rapporten over de arbeidsmarkt in de gezondheidszorg, niet is te achterhalen hoe de arbeidsmarkt voor gezondheidswetenschappers zich op middellange termijn zal ontwikkelen. 
periodieke schriftelijke bevraging van bedrijven behoort een periodieke mondelinge bevraging van sleutelfiguren binnen de werkvelden waarin gezondheidswetenschappers terechtkomen tot de mogelijkheden. In deze mondelinge bevraging, individueel of in groepsbijeenkomsten, kunnen de sleutelfiguren hun visie geven op de middellange-termijnontwikkelingen binnen hun werkveld met betrekking tot de omvang en samenstelling van de werkgelegenheid. Het gebruiken van sleutelfiguren binnen werkvelden als informatiebron heeft twee voordelen boven een benadering van individuele werkgevers. Op de eerste plaats biedt dit de mogelijkheid tot mondelinge bevraging, waarbij veel uitgebreider en dieper op de vragen kan worden ingegaan. Op de tweede plaats kunnen deze informanten vrijer spreken over de ontwikkeling van hun werkveld dan werkgevers dat kunnen over de ontwikkeling van hun organisatie. Nader onderzoek dient uit te maken welke informatiebron de voorkeur verdient. Een derde methode houdt in dat de middellange-termijnontwikkeling van de werkgelegenheid wordt geprognostiseerd op basis van trendanalyses of door het toepassen van econometrische modellen. De hiervoor benodigde inputgegevens zullen moeten worden gegenereerd door de jaarlijkse enquête. Een voorwaarde hiervoor is dat bij het opstarten van de jaarlijkse enquêtering eenmalig historische gegevens worden gevraagd. Deze zullen dan het basisbestand vormen dat vervolgens jaarlijks wordt geactualiseerd. Overigens is het pas mogelijk om prognoses op te stellen als het systeem van jaarlijkse enquêtering is ontwikkeld en goed functioneert.

Een volgend aspect dat in paragraaf 6.2. onder de structurele ontwikkelingen is genoemd, betreft de verdringing van lager door hoger opgeleiden. Inzicht in de eventuele verdringing van lager opgeleiden door hoger opgeleiden kan worden verschaft door een nadere analyse van het databestand dat wordt gegenereerd door de jaarlijkse enquêtes onder werkgevers. De mate van verdringing vormt dus een afgeleid gegeven uit de te houden enquêtes.

Bij het registreren van de (te verwachten) veranderingen in beroepsprofielen gaat het om het waarnemen van veranderingen in de kwalificaties die voor de uitoefening van de onderscheiden functies zijn vereist. Dit zou kunnen geschieden door telkens voor een deel van de functies, volgens een roterend systeem, hierover informatie te verzamelen. Telkens na een periode van enkele jaren wordt dan een compleet beeld verkregen van de profielen van de functies die door gezondheidswetenschappers worden vervuld.

Naast de methode van onderzoek is de keuze van de onderzoekspopulatie van 
belang. Het jaarlijkse onderzoek, dat meerjaarlijks met een aantal extra vragen wordt aangevuld, bestaat uit een gestruktureerde schriftelijke enquête onder hoofden van personeelszaken of personeelsfunctionarissen die zich bezig houden met de werving en de selectie van hoger opgeleiden. Omdat een jaarlijkse benadering van alle werkgevers in de gezondheidszorg, de maatschappelijke dienstverlening en in de aanleverende of ondersteunende instanties en bedrijven niet haalbaar is, kan worden overwogen om de zeer grote werkgevers integraal te benaderen en bij de kleinere werkgevers te volstaan met een selectie. Deze selectie dient een zo nauwkeurig mogelijke afspiegeling te vormen van het actuele werkveld van gezondheidswetenschappers binnen het desbetreffende segment van de arbeidsmarkt en tegelijkertijd indicatief te zijn voor het potentiële werkveld.

De vraag doet zich voor of deze selectie eenmalig dient te geschieden of dat jaarlijks een nieuwe selectie moet worden gemaakt. In het geval van een eenmalige selectie worden telkens dezelfde werkgevers jaarlijks benaderd (panelbenadering). Bij een jaarlijkse selectie kan eventueel met een roterend systeem worden gewerkt, waarbij van de kleinere werkgevers telkens een beperkt en wisselend deel wordt benaderd. Een panelgewijze benadering heeft als voordeel dat ontwikkelingen binnen steeds dezelfde organisaties over een aantal jaren kunnen worden gevolgd. Daarbij kan een band onstaan van de werkgevers in het panel met het periodieke onderzoek, hetgeen de respons en wellicht ook de kwaliteit van de verstrekte gegevens ten goede komt. Wel moet periodiek worden nagegaan of het panel nog steeds representatief is ten aanzien van de populatie van kleinere werkgevers van gezondheidswetenschappers.

Het panel van werkgevers zou kunnen worden gevormd door een steekproef uit een reeds aanwezig bestand van bedrijven en instellingen uit de gezondheidszorg, de maatschappelijke dienstverlening en de aanleverende of ondersteunende instanties en bedrijven. Op dit moment is niet bekend of een dergelijk bestand voorhanden is. Omdat (semi-)overheidsinstellingen niet verplicht zijn tot inschrijving in de registers van de Kamers van Koophandel en Fabrieken, kan de daarop gebaseerde NV Databank hiervan geen bestand leveren. Een dergelijk bestand komt wel beschikbaar met behulp van het jaarlijkse onderzoek onder afgestudeerden.

Een tweede vraag die zich voordoet is of de selectie van een panel van werkgevers moet worden samengesteld op grond van een aselecte steekproef of 
bewust moet worden gekozen op basis van een of meer discriminerende kenmerken. Deze vraag kan pas worden beantwoord wanneer de struktuur van de werkgelegenheid afdoende bekend is. Het gaat hierbij om de werkgelegenheid naar bedrijfstak en bedrijfsgrootte. Deze kan worden bepaald op basis van de resultaten die beschikbaar komen met behulp van het in dit rapport voorgestelde jaarlijkse onderzoek onder afgestudeerden.

De informatieverstrekkers met betrekking tot de veranderingen in de beroepsprofielen kunnen worden gekozen met behulp van een getrapte steekproef. Hierbij worden eerst de organisaties geselecteerd, rekening houdend met het aantal werkzame personen, de aanwezige functies en de manier van produceren c.q. dienstverlenen. Vervolgens worden de informanten binnen de betreffende organisaties geselecteerd.

\subsection{De jaarlijkse vragenlijst voor werkgevers in de gezondheidszorg}

De jaarlijkse vragenlijst met betrekking tot de (toekomstige) ontwikkeling in de omvang en de samenstelling van de werkgelegenheid voor gezondheidswetenschappers dient te bestaan uit de volgende vragenblokken:

I. Algemene- en personeelskenmerken van bedrijf of instelling;

II. De personele samenstelling naar functie en gerelateerd aan gegevens over opleiding en leeftijd;

III. De personeelsbehoefte in de komende 2 jaar;

In blok I wordt gevraagd naar de naam van het bedrijf of instelling die aan de enquête heeft deelgenomen. De vragenlijsten dienen zoveel mogelijk te zijn gesteld op naam van de betreffende personeelsfunctionaris die zich bezig houdt met werving en selectie van hoger opgeleiden. Dit om de nauwkeurigheid van de onderzoeksresultaten te bevorderen en eventuele rappellering, aanvullingen, toelichtingen, vervolgonderzoek etcetera mogelijk te maken. Verder bevat dit blok vragen over de bedrijfstak (volgens SBI) waartoe de organisatie kan worden gerekend. Als relevante personeelskenmerken is gekozen voor het totale aantal daadwerkelijk bezette formatieplaatsen, de totale bruto loonsom (per jaar) en de aanvangssalarissen voor 'starters' uit verschillende opleidingsniveaus en -richtingen.

Blok II bestaat uit vragen over de personele samenstelling naar functie en de opleiding en leeftijd van de vervullers van die functies. Gedacht wordt alleen voor HBO- en WO-gediplomeerden te vragen naar de functies waarin zij 
werkzaam zijn en (voor academici) de faculteit en studierichting waarin zij afstudeerden.

Blok III bevat vragen over de personeelsbehoefte. De vraagstelling hierover valt in twee delen uiteen. Enerzijds moet worden gevraagd om aan te geven hoeveel vacatures er in het afgelopen jaar (inclusief nog openstaande vacatures) bestemd waren voor hoger opgeleiden, in het bijzonder voor academici. Daarbij wordt tevens gevraagd om aan te geven op welke studierichtingen deze vacatures betrekking hadden en of het functies voor 'starters' of 'ervarenen' betrof. Anderzijds dient dit onderdeel een vraag te bevatten naar een onderschatting en een bovenschatting van het verwachte aantal vacatures voor academici en HBO-ers in het komende jaar en het jaar daarop. De Koninklijke Nederlandse Chemische Vereniging (KNCV) en de Werkgroep Arbeidsmarkt voor Ingenieurs (WAI) van het Koninklijk Instituut voor Ingenieurs (KIVI) baseren hun jaarlijkse vacatureprognoses onder werkgevers van respectievelijk chemici en ingenieurs op vergelijkbare vragen. Uit evaluaties is gebleken dat men, althans voor die sector, redelijk goed kan inschatten of de desbetreffende deel-arbeidsmarkten zullen groeien of krimpen.

De ontwikkeling van deze vragenlijst staat overigens nog in de kinderschoenen. Het formuleren van de definitieve vragen en het ontwerpen van een lay-out hebben nog niet plaatsgevonden.

\subsection{Het vooronderzoek onder werkgevers}

Op basis van de eerder genoemde uitgangspunten en een inventarisatie van enkele in de praktijk gebruikte vragenlijsten voor werkgevers (zie paragraaf $6.3)$ is getracht om voor het jaarlijkse onderzoek een concept-vragenlijst samen te stellen. Met personeelsfunctionarissen van een vijftal organisaties is vervolgens een gesprek gevoerd over de ontwikkelde concept-vragenlijst. De keuze voor deze vijf organisaties was gebaseerd op een tweetal criteria. Ten eerste hadden zij allen één of meer afgestudeerden van de Faculteit der Gezondheidswetenschappen van de Rijksuniversiteit Limburg in dienst. Ten tweede verschilden zij onderling sterk in organisatiegrootte. Zo nam het Academisch Ziekenhuis Maastricht als zeer grote instelling aan het werkgeverspanel deel naast kleine organisaties als het Integraal Kankercentrum Limburg en de Provinciale Raad voor de Volksgezondheid. De Districtsgezondheidsdienst zuidelijk Zuid-Limburg en de Faculteit der Gezondheidsweten- 
schappen namen als middelgrote organisaties aan het panel deel.

Voor de gesprekken met de werkgevers/personeelsfunctionarissen werd de volgende probleemstelling gehanteerd: 'welke factoren spelen een rol bij het beantwoorden van een vragenlijst bestemd voor werkgevers van gezondheidswetenschappers'. Deze probleemstelling werd geoperationaliseerd in de volgende onderzoeksvragen:

- Welke factoren bepalen de mogelijkheden voor een gedetailleerde vraagstelling in een schriftelijke vragenlijst, met name als het vragen betreft over functie en opleiding van werknemers?

- Welke factoren bepalen de bereidheid van werkgevers om aan een enquête naar de genoemde personele kenmerken mee te werken?

Deze twee hoofdvragen kwamen tijdens of na het invullen van de conceptvragenlijst aan de orde. Bij het invullen werd verzocht om 'hard-op' te denken.

Op basis van de gevoerde gesprekken kunnen de volgende conclusies worden getrokken:

a. Voordat een werkgever in de gezondheidszorg schriftelijk wordt geënquêteerd, moet worden nagegaan of er sprake is van een (sociaal) jaarverslag en wat de inhoud daarvan is. Enkele van de geconsulteerde personeelsfunctionarissen verwezen voor kengetallen als de totale bruto loonsom en het aantal medewerkers per afdeling naar het jaarverslag. Met name instellingen in de gepremieerde en gesubsidieerde sector kennen een jaarverslagverplichting.

b. De organisatiegrootte is de belangrijkste bepalende factor voor de mogelijkheid om gedetailleerde gegevens te verstrekken. In het algemeen lijkt te gelden dat hoe groter de organisatie is, des te meer moeilijkheden het geeft om vragen over functie en opleiding te beantwoorden op het niveau van individuele medewerkers. Bij kleine organisaties (tot ca. 25 medewerkers) is het invullen van een gedetailleerde vragenlijst een kwestie van in gedachten 'de kamers langsgaan'. Desnoods wordt nog even navraag gedaan. De vragen over de functie en de opleiding op het niveau van individuele werknemers zijn voor middelgrote en grote organisaties vooral moeilijk te beantwoorden wanneer deze aspecten niet of onvolledig in een geautomatiseerd personeelsinformatiesysteem zijn opgenomen.

Vanwege het voorgaande kan worden overwogen om twee vragenlijsten te ontwikkelen: één voor kleine organisaties (tot 20 à 25 medewerkers) en één voor middelgrote- en grote werkgevers. 
Bij kleine organisaties kan worden gevraagd naar de functie, de opleiding en de leeftijd van individuele medewerkers. De vragenlijst voor de (midde1)grote organisaties dient zich te beperken tot een aantal vragen naar opleiding en leeftijd per onderscheiden functiecategorie.

c. De gebruikte 'lijst van functies en beroepsgroepen' moet worden bijgesteld. De respondenten hadden veel moeite om aan de hand hiervan aan te geven welke functies in welke aantallen in de organisatie voorkomen. Dit geldt met name voor de (middel)grote organisaties. Gezien de zeer uiteenlopende karakters van de organisaties in de gezondheidszorg moet worden overwogen om uit ieder potentieel 'werkveld' een specifieke lijst met functies te ontwikkelen. Zo zouden voor de instellingen voor intramurale gezondheidszorg, instellingen voor wetenschappelijk onderwijs en onderzoek, instellingen in de eerstelijnsgezondheidszorg en voor instanties voor coördinatie en advies in de gezondheidszorg, afzonderlijke functieoverzichten moeten worden gemakt. De respondenten kunnen dan in de voor hen van toepassing zijnde goed hanteerbare vragenlijst per functiecategorie een aantal gegevens invullen waaronder het aantal functievervullers, de door hen gevolgde opleidingen en hun leeftijd.

d. Bij kleine organisaties kan redelijk goed worden aangegeven voor welke functies uitbreidingen zijn te verwachten of gewenst zijn. Voor middelgrote en grote organisaties is dat moeilijker. Daar kunnen alleen de richtingen worden aangegeven warin eventuele uitbreidingen of inkrimpingen zullen plaatsvinden.

e. Bij middelgrote en grote organisaties doen zich relatief veel personele veranderingen voor zodat het raadzaam is om deze organisaties jaarlijks te benaderen. Voor kleine organisaties kan wellicht worden volstaan met een tweejaarlijkse enquête.

f. Over het algemeen heeft men geen bezwaren tegen het verstrekken van informatie. Ook niet indien deze wordt gepubliceerd. Het argument hiervoor is veelal dat het toch openbare gegevens betreft. Een enkele kanttekening die werd gemaakt, betrof het geval van tot personen herleidbare informatie. In het geval van openbaarheid zou men zich echter wel voorzichtiger uitlaten over de verwachte uitbreidingen.

g. Naar de mening van één van de respondenten kan een schriftelijke enquête het beste plaatsvinden in de periode mei-september. In deze periode van het jaar worden de respondenten niet in beslag genomen door het opstellen van jaarverslagen over het afgelopen jaar of werkprogramma's voor het voorliggende jaar. 
Alle respondenten verklaarden dat ze zeer regelmatig voor de meest uiteenlopende onderzoeken worden benaderd. Verschillende informanten zeiden de vragenlijst zelfs oningevuld te retourneren als de vraagstelling te vaag of te ingewikkeld is. Bij het ontwikkelen van de definitieve jaarlijkse vragenlijst zal met de bovenstaande zeven conclusies dus rekening moeten worden gehouden.

\subsection{Conclusies}

Om een nauwkeurig beeld te krijgen van de (toekomstige) ontwikkelingen in de omvang en de samenstelling naar functie en opleiding van de werkgelegenheid van afgestudeerden, moet bij een representatief panel van werkgevers van deze afgestudeerden jaarlijks een aantal gegevens worden verzameld.

Voor het verkrijgen van kwantitatieve indicaties over de ontwikkelingen in de omvang van de organisaties waarin de afgestudeerden werkzaam zijn (bijvoorbeeld: totale bruto loonsom en de aantallen medewerkers per dienstverband, afdeling en functie), zouden voor een aantal achtereenvolgende jaren de desbetreffende jaarverslagen kunnen worden geïnventariseerd. Deze basisgegevens zullen moeten worden aangevuld met de resultaten van jaarlijkse, schriftelijke enquêtes onder een panel van werkgevers (personeelsfunctionarissen). Overwogen kan worden om van de jaarlijkse vragenlijst twee varianten te ontwikkelen, één voor kleine organisaties en één voor (middel)grote organisaties. Bij kleine organisaties kan worden gevraagd naar de functie, de opleiding en de leeftijd van individuele medewerkers. Voor (middel)grote organisaties kan de enquête zich beperken tot een aantal vragen per onderscheiden functiecategorie. Hiervoor moeten sectorspecifieke functie-overzichten worden ontwikkeld. Behalve naar de personele samenstelling naar functie, opleiding en leeftijd, moet in de jaarlijkse enquête ook worden gevraagd naar de verwachte personele ontwikkeling op de korte termijn.

De aldus jaarlijks verkregen kwantitatieve gegevens kunnen worden aangevuld met gegevens van meer kwalitatieve aard uit een advertentie-analyse.

De jaarlijkse vragenlijst dient meerjaarlijks te worden aangevuld met een aantal extra vragen met betrekking tot de verwachte personele ontwikkeling op de middellange termijn, het wervings-en selectiebeleid en het loopbaanen scholingsbeleid van werkgevers. 
Overigens zijn voor het bepalen van de middellange-termijnontwikkeling in de omvang en de samenstelling van de vraag naar personeel verschillende methoden mogelijk, die al dan niet in combinatie kunnen worden gebruikt. Naast periodieke schriftelijke bevraging van bedrijven behoort periodieke mondelinge bevraging van sleutelfiguren binnen de sectoren waarin de afgestudeerden terechtkomen tot de mogelijkheden. Een derde methode houdt in dat de middellange-termijnontwikkeling van de werkgelegenheid wordt geprognostiseerd op basis van trendanalyses of door het toepassen van econometrische modellen. De hiervoor benodigde inputgegevens kunnen worden ontleend aan de jaarlijkse enquête.

Om een beeld te krijgen van veranderingen in beroepsprofielen is additioneel periodiek onderzoek nodig, dat aan de uit te voeren enquête-onderzoeken kan worden gekoppeld. De gedachte is om elk jaar slechts een beperkt deel van alle functies die van belang zijn nader te analyseren, zodat steeds na verloop van een periode van enkele jaren een min of meer compleet beeld wordt verkregen. De wijze waarop dit deel van het onderzoek zou moeten worden uitgevoerd is in dit rapport echter niet verder uitgewerkt. 


\section{ORGANISATORISCHE ASPECTEN VAN DE ARBEIDSMARKTSCANNER VOOR ACADEMICI}

\subsection{Inleiding}

De systematische peiling onder afgestudeerden die in dit rapport wordt voorgesteld bestaat uit een jaarlijkse peiling waarbij het gaat om een beperkt aantal vragen met betrekking tot de positie van de afgestudeerden op de arbeidsmarkt. Hiervoor zal het eerste jaar na het afstuderen een "basisvragenkaart" worden gebruikt en vervolgens jaarlijks een "jaarkaart". Additioneel aan deze bevragingen van afgestudeerden dienen ook bij werkgevers periodiek gegevens te worden verzameld. De periodieke bevragingen moeten vergezeld gaan van een voortdurende actualisering van het adressenbestand en de doorlopende uitvoering van activiteiten om de respons hoog te houden.

In dit hoofdstuk zal een aantal voorwaarden worden beschreven waaraan moet worden voldaan teneinde het adressenbestand van de afgestudeerden actueel te kunnen houden en de respons op de enquêtes hoog. Vervolgens worden enkele mogelijkheden geschetst met betrekking tot de voorziening die nodig is voor de systematische peiling onder afgestudeerden. Op de voorziening die nodig is voor het systematisch onderzoek onder werkgevers wordt in een afzonderlijke paragraaf ingegaan.

\subsection{Actualisering adressenbestand en verhoging respons}

Voor het opzetten van het adressenbestand dient in eerste instantie gebruik te worden gemaakt van het studie-adres en het ouderlijk adres (vakantieadres) op het moment van afstuderen. Beide adressen zijn bij de studentenadministraties van zowel de faculteiten als de universiteit bekend. De studentenadministratie van de betreffende faculteit of van de universiteit dient beide adressen op het moment van afstuderen te leveren aan de instantie die met het actualiseren van het adressenbestand is belast. Overigens hoeft dit niet dezelfde instantie te zijn die het onderzoek onder de afgestudeerden verricht.

Een punt van bijzondere zorg bij het actualiseren van het adressenbestand en het uitvoeren van het onderzoek vormt de bereidheid van afgestudeerden om adreswijzigingen door te geven en aan het onderzoek mee te werken. Een middel om oud-studenten te bewegen hun medewerking te verlenen, is het verspreiden van een magazine onder alle oud-studenten. Een dergelijk blad 
dient periodiek te verschijnen en ook artikelen te bevatten op basis van het onderzoek onder de afgestudeerden. Bovendien moet het magazine een antwoordcoupon (port betaald) bevatten om adreswijzigingen door te geven. Overigens kan de "basisvragenkaart" c.q. "jaarkaart" direct worden gekoppeld aan een dergelijke antwoordcoupon. Het is uiteraard van cruciaal belang dat de instantie die het blad verspreid de ingevulde antwoordcoupons meteen doorgeeft aan de instantie die het onderzoek uitvoert.

Omwille van een zo hoog mogelijke respons kan het noodzakelijk zijn om de afgestudeerden niet alleen schriftelijk maar indien nodig ook telefonisch te benaderen. Ook kan worden overwogen om niet alle afgestudeerden integraal te benaderen maar om een steekproef te trekken en deze fractie van afgestudeerden in de vorm van een panelstudie zeer intensief in de tijd te volgen. Met een dergelijke panel-benadering kan een zeer hoge respons worden bereikt. Een nadeel van deze benadering is echter dat ontwikkelingen in de tijd met betrekking tot de positie op de arbeidsmarkt van opeenvolgende cohorten afgestudeerden niet in kaart kunnen worden gebracht.

Regelmatig contact onderhouden met externe relaties (waaronder afgestudeerden) via een professioneel uitgevoerd magazine, wordt de laatste jaren door steeds meer Nederlandse universiteiten op uiteenlopende wijze in praktijk gebracht. Daarmee wordt het voorbeeld van buitenlandse universiteiten gevolgd, die magazines in eerste instantie hebben opgezet voor de werving van fondsen. Het nieuwste magazine binnen de Nederlandse universitaire wereld is "DESIDERIUS" van de Erasmus Universiteit Rotterdam. Het eerste nummer verscheen in september 1988. Vormgeving en inhoud van dit magazine wijzen uitdrukkelijk op een PR-benadering. Het blad "KUZIEN" (Katholieke Universiteit Nijmegen en Academisch Ziekenhuis) vertoont uiterlijk en inhoudelijk veel overeenkomsten met een universiteitsblad. Het blad "CICERO" (Academisch Ziekenhuis en Medische Faculteit Leiden) heeft het karakter van een bedrijfsblad voor medewerkers en externe relaties. Uiterlijk heeft dit blad veel overeenkomsten met commercieel uitgegeven bladen voor kleine doelgroepen. Binnen de jongste universiteit in Nederland, de Rijksuniversiteit Limburg, bestaan plannen om te komen tot een magazine dat is gericht op externe relaties.

De frequentie waarmee deze bladen verschijnen loopt uiteen van veertiendaags, maandelijks tot viermaal per jaar. Sommige bladen worden uitgegeven door een stichting met een eigen redactie en redactieraad of -commissie. 
Andere worden redactioneel verzorgd door een dienst voorlichting, al dan niet ondersteund door een redactieteam. Tot de doelgroepen rekenen de meeste magazines in ieder geval externe relaties, waaronder afgestudeerden. Een aantal bladen beschouwt ook studenten en medewerkers tot hun doelgroepen. De bladen verschillen ook ten aanzien van de prijs die wordt gevraagd voor een abonnement; deze varieert van zestig gulden tot gratis. Vrijwel alle bladen stellen adverteerders in de gelegenheid zich in het blad te presenteren. De exploitatie van de advertenties wordt doorgaans uitbesteed aan een gespecialiseerd bureau. Vormgeving en druk gebeuren meestal ook extern.

Een magazine voor oud-studenten is niet de enige mogelijkheid om de binding van afgestudeerden met de universiteit te versterken en te komen tot een blijvend actueel adressenbestand. Aan de Universiteit Twente (UT) bestaat sinds dit jaar de mogelijkheid voor externe relaties, waaronder afgestudeerden, om tegen betaling lid te worden van de universiteit. Door middel van dit lidmaatschap wil de universiteit externe relaties informeren over en laten participeren in produkten en diensten van de UT, met de bedoeling een tweerichting verkeer te scheppen dat tot een versterkte binding met de universiteit leidt. Bovendien kunnen afgestudeerden via een dergelijk lidmaatschap worden georganiseerd. Het lidmaatschap biedt de mogelijkheid tot het verkrijgen van informatie over ontwikkelingen op de universiteit, het vergroten van de kennis van vakgebieden, het gebruik van allerlei faciliteiten en diensten, en de deelname aan speciale ledenactiviteiten. In een onderzoek naar de haalbaarheid van een dergelijk lidmaatschap is gebleken dat $80 \%$ van de externe relaties positief oordeelt over het lidmaatschapsidee; $31 \%$ denkt zeker en $26 \%$ denkt waarschijniijk 1 id te worden 35 .

Beroeps- of studieverenigingen (bijvoorbeeld apothekers, huisartsen, dierenartsen, landbouwingenieurs, chemici, economen) beschikken doorgaans over een actueel adressenbestand van de aangesloten leden. Ook sommige verenigingen van afgestudeerden van (bepaalde) faculteiten (bijvoorbeeld de Vereniging van Afgestudeerde Econometristen Tilburg of de verenigingen van afgestudeerde bedrijfskundigen van de technische universiteiten) beschikken over adressen van afgestudeerden. Enkele beroepsverenigingen, waaronder de verenigingen van landbouwingenieurs en chemici, verrichten zelfs regelmatig onderzoek naar de arbeidsmarktpositie van de beroepsgroep. Bijna alle

35. Buck Consultants International B.V. (1987). 
ledenbestanden zijn echter ofwel aantoonbaar niet representatief, ofwel het is onbekend in hoeverre ze wel representatief zijn. Met betrekking tot beroepsverenigingen is het aannemelijk om te veronderstellen dat niet werkenden minder snel lid zullen worden van een vereniging.

Ten behoeve van het onderzoek onder afgestudeerden kan dus gebruik worden gemaakt van het geactualiseerd adressenbestand van een magazine, een lidmaatschapsorganisatie van een universiteit, een beroepsvereniging of een vereniging van afgestudeerden. Daarnaast kan de Regionale Adresmutatiedienst van de PTT worden gebruikt als hulpmiddel om te komen tot een blijvend actueel adressenbestand. Deze dienst geeft adresmutaties rechtstreeks door aan deelnemende bedrijven of instellingen. Dit gebeurt door middel van antwoordkaarten die worden ingesloten bij het verhuisbericht dat voor de landelijke "Adresmutatiedienst" wordt gebruikt. Het verhuisbericht plus de ingesloten antwoordkaart(en) zijn gratis verkrijgbaar op postkantoren voor degenen die verhuizen. Bij verhuizing makt ongeveer $94 \%$ van de Nederlandse bevolking gebruik van het verhuisbericht. De regionale adresmutatiedienst wordt vooral gebruikt door regionaal werkende bedrijven en instellingen. Het tarief voor deelneming hangt af van het aantal postkantoren dat voor de verspreiding van de antwoordkaarten wordt ingeschakeld. Het grote nadeel hierbij is dat oud-studenten die buiten de rayons van deze postkantoren (gaan) wonen buiten het systeem (gaan) vallen. Dit kan een groot probleem vormen want academici orienteren zich over het algemeen landelijk bij het zoeken naar een baan. Voor deelneming aan de "Landelijke Adresmutatiedienst" van de PTT dient een bedrijf of instelling echter tenminste 500.000 adressen in haar bestand te hebben.

Het is mogelijk dat de uitvoerder van het onderzoek geen gebruik kan of wil maken van de diensten van derden bij het actualiseren van het adressenbestand. In dat geval moet niet alleen (de verandering ten aanzien van) het woonadres een jaarlijks terugkerend item van de vragenkaart zijn, maar is het tevens noodzakelijk om bij elk geval van adreswijziging intensief te zoeken naar het nieuwe adres. Hierbij dient te worden bedacht dat informeren bij met name ouders, laatst bekende woongemeente/gewestelijk arbeidsbureau, werkgever, etcetera een zeer arbeidsintensieve aangelegenheid is.

\subsection{Voorziening op universitair niveau}

In de vorige paragraaf is een aantal organisaties genoemd die kunnen worden 
betrokken bij het actualiseren van het adressenbestand. Een aantal van deze organisaties, te weten enkele beroepsverenigingen, verricht tevens periodiek onderzoek onder afgestudeerden. Binnen een universitaire organisatie kan het onderzoek onder afgestudeerden op facultair niveau (bijvoorbeeld onderwijsbureau, dekanaat of vereniging van afgestudeerden) of op centraal niveau (bijvoorbeeld dienst onderwijs en onderzoek, dienst studentenzaken, onderzoeksinstituut of lidmaatschapsorganisatie) plaatsvinden. Er zal nu op beide universitaire mogelijkheden worden ingegaan.

Voor het facultair niveau kan pleiten dat afgestudeerden zich wellicht meer verbonden voelen met de faculteit dan met de universiteit waar zij hebben gestudeerd. Voor het facultaire niveau pleit tevens dat dan de terugkoppeling van de beroepspraktijk naar het onderwijs daar wordt gelegd waar het onderwijs wordt aangeboden.

Een onderzoeksvoorziening op centraal niveau waarover meerdere faculteiten kunnen beschikken biedt daarentegen schaalvoordelen met betrekking tot de exploitatie, en garandeert dat het onderzoek onder afgestudeerden binnen een universiteit gecoördineerd en op uniforme wijze plaatsvindt. Daarnaast vormt bundeling van know-how een belangrijk voordeel van een centrale opzet. Het is van groot belang dat een dergelijke voorziening een duidelijk identificeerbaar aanspreekpunt vormt voor medewerkers binnen de universiteit, oudstudenten (en hun ouders) en overige externe relaties (werkgevers en instellingen die gewijzigde adressen kunnen verschaffen). Ook het laatste pleit voor een centrale opzet. Wanneer echter de centrale onderzoeksvoorziening beheersmatig afhankelijk wordt ingekaderd binnen een bestaande centrale dienst zal dit de benodigde duidelijk herkenbare idenditeit niet ten goede komen. Daarbij bestaat bovendien het gevaar dat het verrichten van uitstroomonderzoek ondergesneeuwd raakt tussen de andere taken van de desbetreffende dienst.

Zo lang de activiteiten van de centrale voorziening beperkt blijven tot het verrichten van onderzoek onder afgestudeerden kan zij als beheersmatig onafhankelijke eenheid worden opgehangen aan een centrale dienst of worden ondergebracht in een bestaand onderzoeksinstituut van de universiteit. Ten behoeve van het actueel houden van het adressenbestand kan dan eventueel gebruik worden gemaakt van de aanwezigheid van een magazine, vereniging van afgestudeerden of lidmaatschapsorganisatie van de universiteit. 
Terwille van een zorgvuldig en ordelijk gebruik van enerzijds persoonsgegevens en anderzijds onderzoeksresultaten kan een formele overeenkomst tussen de opdrachtgever en de uitvoerder van het onderzoek worden opgesteld. De "Internationale code voor de praktijk van het markt- en sociologisch onderzoek", die is opgesteld door de Internationale Kamer van Koophandel en de European Society for Opinion and Marketing Research, kan hierbij als richtsnoer dienen. In een dergelijk contract kan een aantal zaken worden geregeld. Hiertoe behoort onder meer de wijze waarop de privacy met betrekking tot de behandeling van gegevens wordt gewaarborgd, de eigendom van het adressenbestand, van het gegevensbestand en van de ontwikkelde meetinstrumenten, de gegevens uit de studentenadministratie die voor onderzoek ter beschikking worden gesteld, de frequentie van rapportering van de onderzoeksresultaten, en de auteursrechten op de onderzoeksresultaten en de rapportages 36 .

Als aanspreekpunt voor concrete onderzoeksvragen van de betrokken faculteit(en) en als klankbordgroep voor de inhoudelijke opzet en uitvoering van het project kan een begeleidingscommissie worden ingesteld. Hierin zullen tenminste zitting moeten hebben vertegenwoordigers van de betrokken universiteit en de faculteit(en), de instantie die de studentenadministratie beheert en eventueel de instantie die het adressenbestand actualiseert.

Mede in verband met het uitstroomonderzoek kan echter te zijner tijd worden besloten om een scala aan activiteiten met betrekking tot afgestudeerden tot ontwikkeling te brengen. Speciaal voor dit doel kan een zelfstandige (externe) voorziening worden opgericht, bijvoorbeeld in de vorm van een stichting, die fungeert als facilitaire voorziening voor de hele universiteit. Een voordeel hiervan is dat eenheid van beleid ten aanzien van afgestudeerden kan worden gewaarborgd. Een probleem vormt evenwel hoe hierin het onderzoek moet worden ingepast. In elk geval dient ter benadrukking van de onafhankelijkheid van het onderzoek te worden gewaarborgd dat het onderzoek beheersmatig onafhankelijk is van de andere activiteiten met betrekking tot de afgestudeerden.

Binnen een dergelijke zelfstandige voorziening kan een scala aan activi-

36. Het College van Bestuur van de RL heeft aan het ROA opdracht verleend om systematisch onderzoek onder afgestudeerden van de RL te verrichten. Daartoe is een formele overeenkomst tussen het ROA en de RL opgesteld waarin bovengenoemde items zijn vastgelegd. 
teiten op een professionele wijze worden uitgevoerd, waarbij het onderzoek en de andere activiteiten elkaar kunnen versterken. Met name de Landbouw Universiteit Wageningen (LUW) kent een dergelijk zelfstandig organisatorisch kader. De Stichting Maatschappelijke Plaats Wageningse Afgestudeerden (MPW), in 1973 opgericht door het Nederlands Instituut van Landbouwkundige Ingenieurs (NILI), vormt een voorbeeld van een zelfstandige voorziening waarbij een aantal activiteiten, gericht op plaatsing van afgestudeerden, in één beleidsmatig en organisatorisch kader is gebundeld. Hierbij moet worden opgemerkt dat de Stichting MPW in Nederland een bijzondere positie inneemt gezien haar directe relatie met een beroepsvereniging.

De activiteiten van de Stichting MPW worden gecoördineerd en uitgevoerd door een werkgroep (bureau), die deels bestaat uit vaste medewerkers en deels uit tijdelijke medewerkers voor specifieke projecten. De kosten van de Stichting MPW worden gedragen door de jaarlijkse bijdrage van het NILI, de vijf-jaarlijkse bijdragen van de afgestudeerden die geen NILI-lid zijn, en door de LUW. Daarnaast wordt een deel van de kosten gedekt door vergoedingen voor specifieke opdrachten en dienstverlening.

De Stichting MPW tracht haar doelstelling, de verruiming van de plaatsingsmogelijkheden van afgestudeerden van de LUW, te bereiken door het (doen) verrichten van een breed scala aan op elkaar afgestemde activiteiten. Deze activiteiten zijn: een jaarlijks onderzoek naar de positie van afgestudeerden op de arbeidsmarkt en een vijf-jaarlijks loopbaanonderzoek onder afgestudeerden; het geven van voorlichting over de arbeidsmarktpositie en de loopbaan van afgestudeerden aan onderwijsgevenden, studenten, afgestudeerden en werkgevers; het bijhouden van een vacaturebank en een geautomatiseerde sollicitantenbank; een uitzendbureau; sollicitatie- en loopbaanbegeleiding; een leergang arbeidsmarktoriëntatie, etc.

Mede ten behoeve van het bovengenoemde onderzoek wordt een adressenbestand van alle afgestudeerden van de LUW bijgehouden. Voor het up-to-date houden hiervan wordt jaarlijks aan alle afgestudeerden een kaart gestuurd met daarop een aantal gegevens waaronder het adres. Gevraagd wordt om eventueel gewijzigde gegevens te verbeteren en de kaart te retourneren.

Bij integratie van beleid, niet onderzoekspecifieke activiteiten en onderzoek bestaat altijd het gevaar dat de onafhankelijkheid van het onderzoek wordt aangetast. Ter benadrukking van deze onafhankelijkheid dient in elk 
geval te worden gewaarborgd dat het onderzoek beheersmatig onafhankelijk is van de andere activiteiten met betrekking tot de afgestudeerden.

\subsection{Voorziening op landelijk niveau}

In het voorgaande is ingegaan op de organisatie van een systematische peiling onder afgestudeerden binnen een universiteit. Het is van belang dat binnen de afzonderlijke universiteiten het onderzoek onder de afgestudeerden op uniforme wijze plaatsvindt. Alleen bij een uniforme wijze van verzamelen en verwerken (met name ten aanzien van methode en moment van dataverzameling, gehanteerde definities en classificaties, codering) kan de voortgebrachte informatie worden ingepast in een landelijk bestand van basisgegevens dat bruikbaar is voor vergelijkingen tussen universiteiten en voor landelijke analyses en prognoses op het niveau van bijvoorbeeld studierichtingen. Dit impliceert dat een voorziening op landelijk niveau nodig is die de volgende taken verricht:

- garanderen dat het verzamelen en het verwerken van gegevens op uniforme wijze plaatsvindt;

- coördineren van de activiteiten die binnen de afzonderlijke universiteiten moeten worden verricht;

- adviseren over de opzet en uitvoering van de universitaire enquêtes;

- opbouwen en bijhouden van een landelijke statistische database;

- beschikbaar stellen van informatie uit deze database ten behoeve van voorlichting, beleid en onderzoek;

- verrichten van analyses en maken van prognoses.

Het verrichten van analyses en het maken van prognoses kan eventueel door andere instanties worden gedaan die over de hiervoor geëigende kennis beschikken.

Een voorziening op landelijk niveau kan in een centrale of in een decentrale opzet uitvoering geven aan een landelijk uniforme wijze van arbeidsmarktonderzoek onder academici. Achtereenvolgens wordt op beide opties voor een landelijke voorziening ingegaan.

In een centrale opzet ligt de uitvoering van het arbeidsmarktonderzoek onder academici geheel in handen van een landelijke instantie. De bijdragen van de verschillende universiteiten beperken zich tot het periodiek doorgeven van adressen (studie-adres en ouderlijk adres) op het moment van afstuderen aan de landelijke instantie. Een centrale opzet garandeert op organisatorisch 
eenvoudige wijze uniformiteit met betrekking tot het verzamelen en het verwerken van de gegevens. Aan een centrale opzet kleven echter ook enkele bezwaren. Afgestudeerden van een universiteit voelen zich wellicht minder verbonden met een voor hen onpersoonlijke landelijke instantie dan met de universiteit waar zij hebben gestudeerd. Dit kan de respons in negatieve zin beïnvloeden. Bovendien is een centrale opzet minder flexibel dan een decentrale opzet waardoor het opnemen van additionele universiteits- of faculteitsspecifieke vragen in het gedrang kan komen. Dit laatste kan tot gevolg hebben dat afzonderlijke universiteiten er alsnog toe overgaan om zelf additioneel onderzoek onder hun afgestudeerden te verrichten. "Overenquêtering" van afgestudeerden en daarmee een lage respons kan het gevolg zijn.

In een decentrale opzet zorgen de afzonderlijke universiteiten voor het verzamelen en het verwerken van de gegevens, alsmede voor het tijdig aanleveren van een dataset aan de landelijke instantie. Deze instantie ziet er op toe dat de activiteiten binnen de afzonderlijke universiteiten op uniforme wijze worden verricht en coördineert deze activiteiten ten behoeve van een geactualiseerd landelijk gegevensbestand. Een belangrijke voorwaarde hierbij is dat de universiteiten als autonome instellingen zich verplichten om ieder jaar mee te werken conform duidelijk vastgestelde instructies. Deze instructies moeten in procedures zijn vastgelegd waarbij contrôle op naleving plaatsvindt. Mede vanwege de eerder genoemde flexibiliteit verdient een decentrale opzet voorkeur boven een centrale benadering. Daarbij komt dat feedback van de onderzoeksresultaten naar de respondenten en de vertaling ervan in universitair en facultair beleid beter mogelijk zijn in een decentrale opzet. Bovendien kan worden aangesloten bij reeds bestaand uitstroomonderzoek binnen universiteiten.

\subsection{Organisatie van het onderzoek onder werkgevers}

Het in hoofdstuk 6 voorgestelde onderzoek met betrekking tot de vraag naar afgestudeerden bestaat uit drie deelonderzoeken:

- een jaarlijkse schriftelijke bevraging van werkgevers, eventueel aangevuld met een meerjaarlijkse uitbreiding van de vragenlijst en een mondelinge bevraging van sleutelfiguren;

- een advertentie-onderzoek;

- een periodiek onderzoek met betrekking tot beroepsprofielen. 
het periodieke onderzoek onder afgestudeerden, kan zowel in een decentrale als in een centrale opzet tevens uitvoering geven aan een landelijk uniforme wijze van jaarlijks schriftelijk onderzoek onder werkgevers. In een decentrale opzet worden de benodigde gegevens verzameld en verwerkt (gecodeerd en ingevoerd) door de afzonderlijke universiteiten. In een centrale opzet gebeurt dit door de landelijke voorziening. Voor een decentrale opzet kan pleiten dat werkgevers wellicht een grotere binding hebben met de universiteit(en) waar het grootste deel van hun academisch gevormd personeel is afgestudeerd dan met een landelijke voorziening. Dit kan de respons in positieve zin bëinvloeden. Een decentrale opzet kan echter leiden tot overlap in de uitvoering van de dataverzameling -en verwerking omdat alle universiteiten, met uitzondering van de Landbouw Universiteit Wageningen, studierichtingen aanbieden die ook aan een of meer andere universiteiten kunnen worden gevolgd. Een arbeidsmarksegment wordt derhalve doorgaans door meerdere universiteiten "bewerkt". De kans is dan ook niet denkbeeldig dat vooral de grotere werkgevers bij een decentrale opzet van de dataverzameling -en verwerking door meerdere universiteiten worden benaderd. Een landelijke dataverzameling bij een landelijk samengesteld panel van werkgevers verdient derhalve de voorkeur.

Het advertentie-onderzoek en het onderzoek met betrekking tot beroepsprofielen kunnen beiden eveneens het beste op landelijk niveau worden uitgevoerd door of in opdracht van de voorgestelde landelijke voorziening. Schaalvoordelen, de mogelijkheid tot bundeling van know-how, het waarborgen van uniformiteit met betrekking tot de gehanteerde onderzoeksmethoden en in de wijze van verslaglegging alsmede het voorkomen van overlap zijn argumenten die pleiten voor een uitvoering op landelijk niveau.

\subsection{Conclusies}

Het verdient aanbeveling om de systematische peiling onder afgestudeerden beheersmatig onafhankelijk te organiseren als een facilitaire voorziening ten behoeve van de hele universiteit. Het scheppen van één voorziening biedt schaalvoordelen met betrekking tot de exploitatie, garandeert dat het onderzoek gecoördineerd en op uniforme wijze plaatsvindt, maakt bundeling van professionele know-how mogelijk, en biedt één aanspreekpunt voor belanghebbenden. Ten behoeve van een dergelijke onderzoeksvoorziening kan een aparte voorziening in het leven worden geroepen. Deze voorziening kan echter ook deel uitmaken van een (reeds bestaande danwel op te richten) 
voorziening met meer taken dan alleen het verrichten van systematisch onderzoek onder afgestudeerden. In het laatste geval voorkomt een beheersmatig onafhankelijke opzet van de onderzoeksvoorziening of uitbesteding aan een onderzoeksinstituut het gevaar dat een vermenging optreedt van onderzoek en beleid en het onderzoek ondergesneeuwd raakt tussen de andere taken van de desbetreffende voorziening. Bovendien is een beheersmatig onafhankelijke opzet bevorderlijk voor de eigen identiteit van de onderzoeksvoorziening.

Ten behoeve van de systematische peiling onder afgestudeerden kan gebruik worden gemaakt van het geactualiseerd adressenbestand van een magazine voor externe relaties (waaronder oud-studenten), een lidmaatschapsorganisatie van een universiteit, een beroeps- of studievereniging of een vereniging van afgestudeerden. Vooral een magazine kan de bereidheidheid van oud-studenten om aan het onderzoek mee te werken vergroten. Een magazine biedt namelijk een efficiënte mogelijkheid om de onderzoeksresultaten periodiek terug te koppelen naar de respondenten.

Een begeleidingscommissie kan fungeren als aanspreekpunt voor onderzoeksvragen van de faculteiten en als klankbordgroep voor de inhoudelijke opzet en uitvoering van de systematische peiling.

In een formele overeenkomst tussen de opdrachtgever en de uitvoerder van het onderzoek kunnen afspraken worden vastgelegd die een zorgvuldig en ordelijk gebruik van persoonsgegevens en onderzoeksresultaten moeten waarborgen.

Het is van groot belang dat het verzamelen en het verwerken van de gegevens binnen de afzonderlijke universiteiten op uniforme wijze plaatsvindt. Alleen dan kan een statistische database onstaan die bruikbaar is voor analyses en prognoses op landelijk niveau. Om deze uniformiteit te kunnen waarborgen en een landelijk bestand van basisgegevens te kunnen bijhouden dient een voorziening op landelijk niveau in het leven te worden geroepen. De landelijke voorziening die bij voorkeur in een decentrale opzet uitvoering geeft aan het periodieke onderzoek onder afgestudeerden, dient in een centrale opzet tevens uitvoering te geven aan het periodieke onderzoek met betrekking tot de vraag naar afgestudeerden. 


\section{OUTPUT VAN DE ARBEIDSMARKTSCANNER VOOR ACADEMICI}

\subsection{Inleiding}

De in hoofdstuk 5 en hoofdstuk 6 gepresenteerde systematische arbeidsmarktpeiling bestaat uit twee soorten bevragingen die elkaar aanvullen:

- jaarlijkse bevraging van afgestudeerden met betrekking tot de positie op de arbeidsmarkt en de daarin opgetreden veranderingen;

- jaarlijkse bevraging van werkgevers met betrekking tot de (toekomstige) vraag naar universitair opgeleiden.

Iedere soort bevraging genereert haar eigen specifieke gegevens. Om binnen iedere soort bevraging vergelijkingen in de tijd en tussen universiteiten mogelijk te maken, dient te worden gestreefd naar standaardisering van de onderzoeksoutput. Deze bestaat uit een statistische database en (standaard)rapportages.

Een statistische database die bruikbaar is voor analyses en prognoses op landelijk niveau en koppelbaar is aan andere bestanden impliceert, zoals in hoofdstuk 2 reeds is opgemerkt, uniformiteit met betrekking tot:

- de gehanteerde definiëring van de vragen (standaarddefinities) en de classificatie van de antwoorden (standaardclassificaties) bij het verzamelen van de data;

- codering van de ruwe data en ontbrekende waarden, invoer van de gecodeerde data, en contrôle op logische fouten.

Standaardrapportages impliceren uniformiteit met betrekking tot:

- de verwerking (waaronder het toekennen van labels aan variabelen en categorieën ervan, alsmede het behandelen van ontbrekende waarden);

- de analyse (waaronder de berekening van nieuwe, meestal afgeleide variabelen);

- de interpretatie van de analyseresultaten en de presentatie van de onderzoeksbevindingen.

In de vorige hoofdstukken is uiteengezet hoe door middel van de systematische peiling onder afgestudeerden en werkgevers periodiek en op consistente wijze informatie kan worden gegenereerd. De resultaten van de periodieke enquêtering van afgestudeerden en werkgevers kunnen aan de in paragraaf 2.3. genoemde groepen belanghebbenden worden verstrekt in de vorm van 
voor hen passende standaardrapportages. In paragraaf 8.2. worden twee voorbeelden van standaardrapportages beschreven. Tot slot wordt een overzicht gegeven van standaardrapportages die voor elk van de onderscheiden groepen belanghebbenden geschikt lijken.

\subsection{Twee voorbeelden van standaardrapportages}

Hieronder worden twee voorbeelden geschetst van standaardrapportages over achtereenvolgens de instroom op de arbeidsmarkt (Groot-Brittannië) en het verloop van de beroepscarrière (LUW).

In hoofdstuk 4 is beschreven op welke wijze de Association of Graduate Careers Advisory Services uit Groot-Brittannië aan het eind van elk kalenderjaar een first-destination survey onder de afgestudeerden uit het voorgaande studiejaar verricht. De Universities' Statistical Record publiceert de resultaten jaarlijks in een basis-tabellenboek met als titel University Statistics 19..-.. First Destinations of University Graduates. In dit basis-tabellenboek is, onderverdeeld naar geslacht en vervolgens uitgesplitst naar studierichting (voor achtereenvolgens "first degree graduates" en "higher degree graduates"), informatie opgenomen over aantallen afgestudeerden naar eerste bestemming, "employer categories", "type of work" en geografische bestemming bij werk of studie in het buitenland.

In de tabellen worden 16 clusters van verwante studierichtingen onderscheiden. Deze worden in alle tabellen (met uitzondering van de tabel over de geografische bestemming in het buitenland) verder uitgesplitst naar in totaal 112 studierichtingen.

In het basis-tabellenboek wordt niet alle informatie opgenomen. De Universities' Statistical Record verstrekt op verzoek meer gedetaileerde statistische informatie over de onderwerpen die in het basis-tabellenboek aan bod komen.

De Stichting MPW verricht vanaf 1973 vijfjaarlijks loopbaanonderzoeken onder afgestudeerden van de LUW. De loopbaanenquêtes zijn erop gericht uitvoerige inlichtingen te verkrijgen over de functies die door afgestudeerden worden vervuld. Op grond hiervan wordt voorlichting gegeven aan (aankomende) studenten, afgestudeerden, werkgevers, instanties op het gebied van onderwijsplanning en arbeidsmarkt, en aan faculteiten en vakgroepen van de LUW. Van deze onderzoeken verschijnt om de vijf jaar een algemeen eindverslag in 
boekvorm. De in het vijfjaarlijkse algemene eindrapport gehanteerde invalshoeken zijn afstudeerjaar, geslacht en (tropische of westerse) oriëntatie 37 . In het rapport komen achtereenvolgens aan bod: (ontwikkelingen met betrekking tot) deelname aan het arbeidsproces, functiekenmerken, aansluiting van functie en opleiding, aspecten van de arbeidsmarkt, functiemobiliteit, zelfstandig ondernemen en buitenlandse werkervaring. Deze gegevens worden in de vorm van kruistabellen gepresenteerd en voorzien van een uitgebreide toelichting. De gegevens die door middel van de loopbaanenquête zijn verzameld omvatten meer informatie dan in het algemeen eindrapport kan worden opgenomen. In afzonderlijke rapporten per studierichting wordt meer gedetailleerde informatie gegeven over de functies van afgestudeerden van iedere studierichting.

\subsection{Presentatie van de output}

Door middel van de systematische peiling onder afgestudeerden en werkgevers komen periodiek actuele onderzoeksgegevens en een geactualiseerd adressenbestand van externe relaties ter beschikking.

De output van het geactualiseerd adressenbestand kan de vorm aannemen van een gids of tape/floppy met adressen van externe relaties, waaronder oudstudenten. Hiervoor is uiteraard toestemming van betrokkenen nodig. In een dergelijke gids (of floppy) kunnen de adressen naar een of meerdere gezichtspunten worden gerubriceerd (bijvoorbeeld naar faculteit, jaar van afstuderen, regio). De belangstelling voor dergelijke adreslijsten lijkt groot te zijn, zoals onder meer is gebleken uit de proefenquête van de basisvragenkaart en de jaarkaart onder gezondheidswetenschappers.

De output van het geactualiseerd bestand van onderzoeksgegevens bestaat in geautomatiseerde vorm uit een (landelijke) statistische database op tape. Deze tape kan aan een gespecialiseerd onderzoeksinstituut ter beschikking worden gesteld voor het verrichten van analyses en het maken van prognoses op het niveau van bijvoorbeeld studierichtingen. In dit kader kan worden gewezen op het in paragraaf 2.3. behandelde informatiesysteem voor onderwijs en arbeidsmarkt dat door het ROA wordt ontwikkeld.

Bij het verrichten van analyses en het maken van prognose kan onderscheid

37. NILI/MPW (1984)。 
worden gemaakt tussen "standaardanalyses en- prognoses" en specifieke analyses en prognoses. Bij standaardanalyses en- prognoses gaat het om structurele activiteiten die periodiek en volgens een steeds gelijke systematiek worden verricht. De output bestaat uit standaard-onderzoeksresultaten die in de vorm van standaardrapportages periodiek beschikbaar komen. In paragraaf 8.2. zijn twee voorbeelden geschetst van dergelijke standaardrapportages. Bij specifieke analyses en prognoses gaat het om "maatwerk" ten behoeve van specifieke, te zijner tijd actuele onderzoeksbehoeften of -problematiek. Hierover kan in specifieke rapportages verslag worden gedaan.

Aangezien de informatiebehoefte van de verschillende groepen belanghebbenden nogal uiteenloopt is het raadzaam om diverse publikatievormen te ontwikkelen. In paragraaf 2.3. is de specifieke informatiebehoefte van verschillende doelgroepen geschetst.

Kiezers van een studie of beroep kunnen worden benaderd in de vorm van een "wegwijzer" waarin de (toekomstige) kansen op werk en de (latere) beroepsmogelijkheden van de verschillende studie/afstudeerrichtingen op eenvoudige en overzichtelijke wijze worden gepresenteerd. Een dergelijke wegwijzer dient voor voorlichters over studie en beroep, alsmede voor bedrijven en instanties die werkzaam zijn op het gebied van arbeidsbemiddeling, uitgebreider te zijn en meer gedetailleerde informatie te bevatten. Een aanzienlijk efficiëntere en rijkere informatiebron dan een dergelijke wegwijzer kan worden gevormd door een gebruiksvriendelijk geautomatiseerd systeem voor de studie- en beroepskeuze zoals dat in het kader van het ISEE! project wordt ontwikkeld38. Ook voor werkgevers zou een dergelijke (geautomatiseerde) wegwijzer, met daarin informatie over onder meer aantallen afgestudeerden en hun beroepsmogelijkheden, kunnen worden ontwikkeld. Voor de capaciteitsplanning van het onderwijs bij faculteiten,

38. De naam I-SEE! staat voor Information System on Education and Employment. Door middel van dit systeem krijgen studie- en beroepskiezers langs menugestuurde wegen toegang tot gegevens over opleidingen, met deze opleidingen te vervullen beroepen en de arbeidsmarktperspectieven van deze opleidingen en beroepen. De bijdrage van het ROA aan het I-SEE! project betreft het berekenen en analyseren van de arbeidsmarktsituatie en -perspectieven van beroepen en opleidingen. I-SEE! zal in exploitatie worden genomen door het Landelijk Dienstverlenend Centrum (LDC) i.o. Het LDC zal een onafhankelijke stichting vormen die is opgezet vanuit het Ministerie van Onderwijs en Wetenschappen en het (toekomstige) Centraal Bestuur voor de Arbeidsvoorziening. 
universiteiten of de rijksoverheid zal men vooral behoefte hebben aan een presentatie van onderzoeksgegevens in de vorm van gedetailleerde cijfermatige overzichten waarop secundaire analyses kunnen worden verricht. Dit betekent dat een tabellenboek ontwikkeld moet worden waarin de gegevens in een zeer gedesaggregeerde vorm zijn opgenomen.

Bij het voorgaande gaat het om standaard-onderzoeksresultaten die in verschillende standaard-publikatievormen worden gepresenteerd. Onderwijsgevenden en ontwerpers van curricula binnen faculteiten zijn meer gebaat bij specifieke, kwalitatieve informatie over beroepsprofielen, functie-uitoefening en de daarvoor benodigde kennis en vaardigheden. Voor het presenteren van dergelijk specifieke informatie zijn standaardpublicaties alleen geschikt wanneer het zou gaan om periodiek disciplinegewijs onderzoek. Ook zou een publikatie kunnen worden ontwikkeld waarin jaarlijks een algemeen overzicht wordt gegeven van de belangrijkste resultaten van de analyses en prognoses. Een dergelijke publikatie moet een toegankelijk totaalbeeld bieden van de hiervoor beschreven publikaties voor specifieke doelgroepen. In het eerder genoemde informatiesysteem onderwijs-arbeidsmarkt, dat in opdracht van het Ministerie van Onderwijs en Wetenschappen door het ROA wordt ontwikkeld, is voorzien in het periodiek beschikbaar komen van dergelijke analyse- en prognoseresultaten.

\subsection{Conclusies}

De systematische peiling onder afgestudeerden en werkgevers genereert periodiek enquêtegegevens en geactualiseerde adressen van externe relaties. Het adressenbestand kan in geautomatiseerde vorm en als gids worden verspreid. De enquêtegegevens dienen te worden opgeslagen in een statistische database die aan tenminste twee eisen moet voldoen. De eerste eis betreft de bruikbaarheid voor analyses en prognoses op landelijk niveau en de daarmee samenhangende koppelbaarheid aan andere bestanden. Dit impliceert dat het verzamelen en het verwerken van de gegevens binnen de afzonderlijke universiteiten op uniforme wijze moet plaatsvinden, met gebruikmaking van standaarddefinities en standaardclassificaties. Een voorziening op landelijk niveau dient hierover te waken. In de tweede plaats moet de database toegankelijk zijn voor onderzoekers. Dit impliceert dat de enquêtegegevens in geautomatiseerde vorm worden opgeslagen in een dergelijke database. De enquêtegevens kunnen dan op tape aan onderzoekers ter beschikking worden gesteld voor het verrichten van analyses en het maken van prognoses. De resultaten van de 
analyses en prognoses dienen periodiek aan de onderscheiden groepen belanghebbenden te worden verstrekt in de vorm van voor hen passende standaardrapportages. Voor kiezers van een studie of beroep kunnen de kansen op werk, de beroepsmogelijkheden, het te verwerven inkomen en de carrièremogelijkheden van de verschillende opleidingen worden gepresenteerd in de vorm van een wegwijzer. Een dergelijke wegwijzer dient voor voorlichters over studie en beroep uitgebreider te zijn. Het is ook mogelijk om de informatie betreffende studie- en beroepskeuze aan te bieden in de vorm van een gebruiksvriendelijk geautomatiseerd systeem zoals het eerder genoemde I-SEE! waarin het ROA de arbeidsmarktmodule voor zijn rekening neemt. Ten behoeve van werkgevers kan informatie over met name de toekomstige uitstroom uit de verschillende opleidingen en de mogelijkheden van deze opleidingen tijdens de beroepsuitoefening eveneens in de vorm van een (geautomatiseerde) wegwijzer worden gepresenteerd. Voor capaciteitsplanners in het onderwijs kan cijfermatige informatie over met name de omvang en samenstelling van de toekomstige uitstroom uit de diverse opleidingen en de vraag op de arbeidsmarkt naar deze opleidingen in de vorm van een basis-tabellenboek beschikbaar komen. Voor onderwijsgevenden en ontwerpers van curricula kan kwalitatieve informatie over de doelmatigheid van de opleiding in relatie tot de eisen die de beroepsuitoefening stelt in de vorm van disciplinerapporten beschikbaar komen. 


\section{LITERATUUR}

Buck Consultants International B.V. (1987), Lidmaatschap van een universiteit. Onderzoek in opdracht van College van Bestuur Universiteit Twente, Nijmegen.

Centraal Bureau voor de Statistiek (1988-I), Statistiek van het Hoger Beroepsonderwijs 1985/'86, instellingen en studenten, 's-Gravenhage.

Centraal Bureau voor de Statistiek (1988-II), Statistiek van het Wetenschappelijk Onderwijs 1984/'85 en 1985/'86, 's-Gravenhage.

Centraal Bureau voor de Statistiek (1988-III), Vragenlijst Enquête Beroepsbevolking, Voorburg/Heerlen.

Centraal Bureau voor de Statistiek (1989), Behaalde doctoraal examens bij het wetenschappelijk onderwijs, studiejaar 1987/'88, Statistisch Bulletin $23,15 / 6 / 89$.

Commissie Struktuur en Financiering Gezondheidszorg (1987), Bereidheid tot verandering.

Dam, J.W. van, A. de Grip, J.A.M. Heijke (1988), Op zoek naar informatiebronnen over de arbeidsmarktpositie van academici, ROA-W-1988/3, Maastricht.

Es, M. van, E. van der Weerd, B. Wilbrink (1988), Arbeidsmarkt Medische Biologie, SCO-Rapport 169, Amsterdam.

Grip, A. de (1987), Onderwijs en Arbeidsmarkt: Scholingsdiscrepanties, VUuitgeverij, Amsterdam.

Grip, A. de, J.A.M. Heijke, R.J.P. Dekker, L.F.M. Groot, L.A. Vos (1987), De arbeidsmarktperspectieven van studierichtingen in het wetenschappelijk onderwijs 1992, arbeidsmarktmodule I-SEE! project, Researchcentrum voor Onderwijs en Arbeidsmarkt, ROA-R-1987/3, Maastricht.

Heijke, J.A.M. (1986), Het Researchcentrum voor Onderwijs en Arbeidsmarkt, ROA-R-1986/1, Maastricht.

Johnes, G., J. Taylor, G. Ferguson (1987), The employability of new graduates: a study of differences between UK universities, in: Applied Economics, nr. 19, p. 695-710.

Kramer, C., M.L. Schreurs (1988), Beroepsperspectief van Gezondheidswetenschappers, Verslag van een enquête onder afgestudeerde gezondheidswetenschappers, Rijksuniversiteit Limburg, Faculteit der Gezondheidswetenschappen.

Maesen, van der (1987), Transformatie van de gezondheidszorg in Nederland tussen 1974 en 1987.

Ministerie van Onderwijs en Wetenschappen (1987), Ontwerp Hoger Onderwijs en Onderzoek Plan, 's-Gravenhage.

Ministerie van Welzijn, Volksgezondheid en Cultuur (1988), Taakstelling Beroepskrachtenplanning Gezondheidszorg 1988, Rijswijk. 
Muysken J. (1984), Structurele en conjuncturele werkloosheid, in: Maandschrift Economie 48 (3), p. 193-217.

Nationaal Ziekenhuis Instituut (1987), Intramurale gezondheidszorg in cijfers 1987, Utrecht.

Nationaal Ziekenhuis Instituut (1989), Vragenijijst voor Enquête Personeelssterkte 1988, Utrecht.

Nederlands Instituut van Landbouwkundig Ingenieurs/Stichting Maatschappelijke Plaats Wageningse Afgestudeerden (1984), De Wageningse ir. in functie, Loopbaanenquête 1983, Eindrapport Deel I en II, Wageningen.

Nederlands Instituut voor onderzoek van de Eerstelijnsgezondheidszorg(1987), Cijfers uit de registratie van beroepen in de eerstelijnsgezondheidszorg 1987, Utrecht.

Ontario Institute for Studies in Education (1988), Employment Survey of 1985 Graduates of Ontario Universities, Quebec, Canada.

Over voorzieningen, gebruik en personeel in de kwartaire sector 1983-1987 (1983), Eindrapport van de Commissie Ramingen Kwartaire Sector, Ministerie van Binnenlandse Zaken/Sociaal en Cultureel Planbureau, 's-Gravenhage.

ROA-R-1989/1, Naar een informatiesysteem onderwijs-arbeidsmarkt, ROA-onderzoekprogramma 1989-1990, 1989, Maastricht.

Siebers, A.M. (1987), Waar zijn ze gebleven?, Enquête onder afgestudeerde Leidse biologen, Rijksuniversiteit Leiden.

Sociaal en Cultureel Planbureau (1984), Trendrapport Kwartaire Sector 19831990, SCP-Cahier 43, Rijswijk.

Sociaal en Cultureel Planbureau/Centraal Planbureau (1984), Arbeidsvraag en Arbeidsaanbod in de gezondheidszorg op lange termijn, Project Personeelsvoorziening Kwartaire Sector, Bulletin no. 5, 's-Gravenhage.

Sociaal Economische Raad (1988), Advies sociaal-economisch beleid op middellange termijn 1988-1992, 's-Gravenhage.

Taakgroep Studentenramingen (1986), Wetenschappelijk Onderwijs Raming Studenten Aantallen 1986-2000, 's-Gravenhage.

Tichelaar, M. (1987), Biologen en biologieleraren op de arbeidsmarkt, Resultaten van een enquête onder afgestudeerden aan de universiteiten, NIBIArbeidsmarktonderzoek 4, Utrecht.

Tweede Kamer der Staten-Generaal, Financieel Overzicht Zorg 1989, vergaderjaar 1988-1989, 20 848, nrs. 1-2.

Twijnstra Gudde NV management consultants (1986), Rijksuniversiteit te Leiden. Gezondheidswetenschappen en de arbeidsmarkt. Een analyse van de vraag naar en het profiel van onderzoekers op het gebied van bescherming en bevordering van de gezondheid van de mens, Deventer.

Vereniging van Samenwerkende Nederlandse Universiteiten (1988), Gids voor de externe kwaliteitszorg, Utrecht. 
Wajon, M.H.A.M. (1986), IFLO, Ergonomie en bedrijven, Een verkennend onderzoek naar beroepsmogelijkheden en een analyse van de implicaties voor de IFLO, doctoraalscriptie, Vakgroep Functionele Anatomie, Interfaculteit voor Lichamelijke Opvoeding, Vrije Universiteit, Amsterdam.

Wetenschappelijke Raad voor het Regeringsbeleid (1987), Ruimte voor groei, Staatsuitgeverij, 's-Gravenhage. 





Maastricht, mei 1989

Beste gezondheidswetenschapper,

Het is nu al weer ruim een jaar geleden, dat $u$ de Faculteit der Gezondheidswetenschappen van de Rijksuniversiteit Limburg (RL) heeft verlaten. Wij zijn dan ook geinteresseerd in de ervaringen die $u$ het afgelopen jaar heeft opgedaan. Bijvoorbeeld of $u$ na uw universitaire opleiding een baan heeft kunnen vinden. Om dit aan de weet te komen vragen wij u om mee te werken aan een periodiek loopbaanonderzoek onder afgestudeerden van de RL.

Door het invullen van de basisvragenkaart draagt $u$ er toe bij dat wij onze opleiding beter kunnen afstemmen op de praktijk. Deze gegevens zijn belangrijk voor jongeren die nog een studiekeuze moeten maken. Onze huidige en toekomstige studenten kunnen dan zien welke richtingen je met gezondheidswetenschappen op kunt.

In dit loopbaanonderzoek werkt de Faculteit der Gezondheidswetenschappen samen met het Researchcentrum voor Onderwijs en Arbeidsmarkt (ROA) van de RL. De coördinatie van dit onderzoekproject is voorlopig in handen van het ROA. Op termijn zal echter worden gestreefd naar een onafhankelijke stichting. Deze stichting zal de universiteit behulpzaam zijn bij het ontplooien van activiteiten ten behoeve van afgestudeerden aan de RL. Als $u$ wilt deelnemen aan deze activiteiten kunt $u$ dat op de basisvragenkaart aangeven.

De door $u$ op de basisvragenkaart ingevulde gegevens zullen anoniem voor het bovengenoemde loopbaanonderzoek worden gebruikt.

De ingevulde basisvragenkaart kunt $u$ in de bijgevoegde antwoordenveloppe zonder postzegel sturen naar het ROA. Liefst zo snel mogelijk. Over enkele maanden zal een samenvattend verslag van het loopbaanonderzoek verschijnen. Indien $u$ daarvoor belangstelling heeft kunt $u$ dit kenbaar maken op de basisvragenkaart. Meer informatie kunt u krijgen bij dhr. G. Ramaekers, ROA, Postbus 616, 6200 MD Maastricht, telefoon 043 - 888852.

We hopen dat $u$ mee wilt werken aan dit loopbaanonderzoek. Alvast hartelijke dank en veel succes in de toekomst.

\section{INSTRUCTIES VOOR HET INVULLEN VAN DE VRAGEN}

Lees eerst onderstaande instructies voordat u de vragen gaat beantwoorden!

De enquête bestaat uit een basisvragenkaart en een bijbehorende toelichting op de vragen. Alle antwoorden noteert $u$ alléén op de basisvragenkaart. Lees bij iedere vraag eerst de bijbehorende toelichting. Noteer daarna het antwoord. Deze toelichting heeft $u$ nodig om te weten welke codenummers $u$ bij het invullen van de basisvragenkaart dient te gebruiken.

Een aantal antwoorden op de basisvragenkaart is reeds voorgedrukt aan de hand van gegevens uit het bestand van de Faculteit der Gezondheidswetenschappen. Alleen gegevens die niet, onvolledig of onjuist zijn genoteerd, dient $u$ uitsluitend in de daarvoor bestemde hokjes in te vullen. Noteer de antwoorden altijd in blokletters en neem codenummers uit de toelichting bij de vragen nauwkeurig over. De verwerking van de basisvragenkaarten gaat dan veel vlotter.

ALVAST HARTELIJKE DANK VOOR UW MEDEWERKING! 
1. naam:

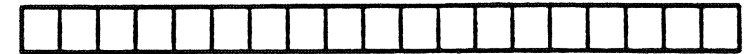

3. stratnace:

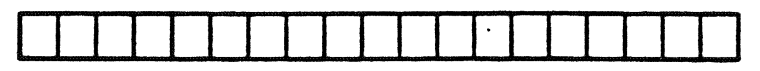

5. woonplaats:

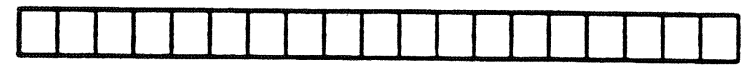

7. Iand:

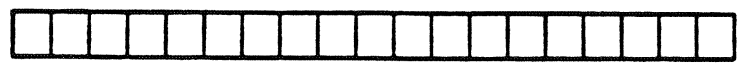

9. geboortejaar: $\square$

11. vooropleiding: $\square$

12. (werk)ervaring:

werk:

2. voorletters:

4. huil snumaer:

6. postcods:

8. telefoon:

10. geslaent: $M=1$

$y=2$
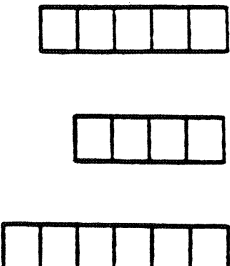



B.

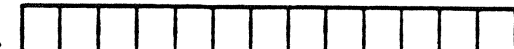

af studeerrichting: $A$.

B.

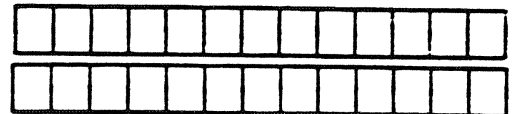

14. aanvang studie: waand

\begin{tabular}{|l|l|l|}
\hline$P$ & 0 \\
\hline
\end{tabular}

15. Inde studie: wand

\begin{tabular}{|l|l|l|}
\hline 9 & \\
\hline
\end{tabular}

16. huidige situatie:

17. werkzoekend:

18. bezigheden april t/m mart 1989:

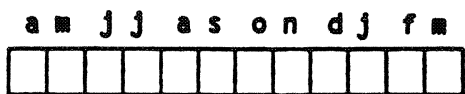

Wiet elke vrag hoeft voor u relevant te zijn (zie toelleinting)

19. verensering punctle: $\square$

20. verandering werkgever: $\square$

21. Puncti werving:

22. dienstverband:

23. tijdsdur anstelling:

24. erbeldsuren:

25. beroepsgroep:

26. Punctienaam:

27. Ielding:

28. Inkomen:

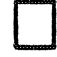

29. Branchegroep:

30. man + werkadres:

31. dienst/produkt:

32. personeel somvang:

33. zoekmethoden:

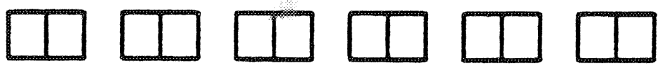

34. beschikbaarheid:

35. oplelding: eard: $\square$ rienting: $\square$ naan:

36. deinae aktiviteiten: $\square \square \square \square \square \square \square \square \square$ 37. versiag onderzoek: 
ALLEEN DE ANTWOORDEN DIE NIET, ONJUIST OF ONVOLLEDIG ZIJN VOORGEDRUKT INVULLEN! GEBRUIK UITSLUITEND DE DAARVOOR BESTEMDE HOKJES.

Vraag 1: Gehuwde vrouwen dienen hier alleen hun meisjesnaam te vermelden.

Vraag 8: Plaats tussen netnummer en abonneenummer een liggend streepje (-).

Vraag 11: Noteer het codenummer dat uw hoogste vooropleiding vooór de RL-studie het beste weergeeft.

$1=$ VWO-diploma

$2=$ HBO-opleiding met diploma

$3=$ HBO-opleiding zonder diploma

$4=$ Reeds in andere universitaire studie doctoraaldiploma behaald

$5=$ Reeds andere universitaire studie gevolgd; geen doctoraaldiploma

$6=$ andere vooropleiding

Vraag 12: Vul voor de categorieën werk, assistent en overig het codenummer in, dat het beste past bij uw ervaring voór/tijdens uw studie aan de RL. Indien per categorie meerdere antwoorden van toepasssing zijn, noteer dan het hoogste cijfer.

betaald werk:

$0=$ geen werkervaring/vakantiewerk/weekendwerk
$1=$ part-time/full-time baan hooguit 1 jaar; buiten gezondheidszorg
$2=$ part-time/full-time baan hooguit 1 jaar; binnen gezondheidszorg
$3=$ part-time/full-time baan langer dan 1 jaar; buiten gezondheidszorg
$4=$ part-time/full-time baan langer dan 1 jaar; binnen gezondheidszorg

assistent:

$0=$ geen ervaring als studentassistent

$1=$ wel ervaring als studentassistent

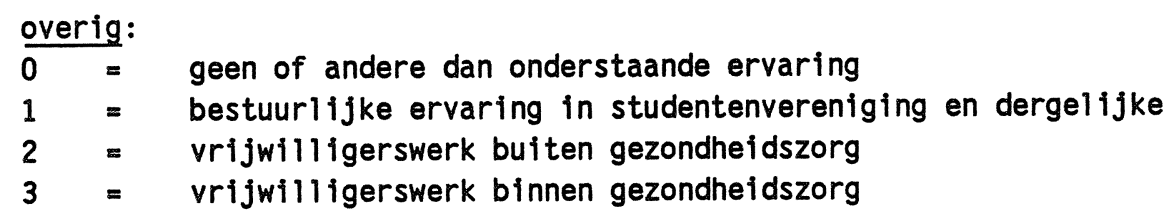

Vraag 13: Noteer hier de door u gevolgde universitaire studierichting(en) met bijbehorende afstudeerrichting(en) waarvoor $u$ uw doctoraaldiploma heeft behaald. Indien $u$ naast de bij $A$ voorgedrukte universitaire opleiding nog meer universitaire opleidingen met een doctoraaldiploma heeft afgesloten, noem van deze dan alleen diegene die $u$ het laatste heeft behaald.

Vraag 14: Geef hier maand en jaar aan waarop u met uw studie gezondheidswetenschappen aan de RL bent begonnen.

Vraag 15: Geef hier maand en jaar aan waarop u uw studie gezondheidswetenschappen aan de RL heeft beëindigd.

Vraag 16: Deze vraag betreft uw huidige situatie. Als u onderstaande mogelijkheden bekijkt, waartoe rekent u zich dan? Vul het codenummer in dat het beste past bij uw huidige situatie. $U$ kunt slechts één codenummer invullen.




Bij codenummer 1 gaat $u$ na het beantwoorden van vraag 17 en 18 verder met vraag 19; indien u meer dan één baan heeft, hebben de vragen 19 tot en met 32 alleen betrekking op de baan met de meeste arbeidsuren.

Bij de overige codenummers gaat $u$ na het beantwoorden van vraag 17 en 18 verder met vraag 33 .

Vraag 17: Bent u op zoek naar een (andere) baan voor uzelf?

$$
\begin{aligned}
& 1=\text { ja } \\
& 2=\text { nee }
\end{aligned}
$$

Vraag 18: Noteer voor ledere maand in de periode april $1988 \mathrm{t} / \mathrm{m}$ maart 1989 het codenummer dat het beste past bij de dagelijkse bezigheden die $u$ toen had.

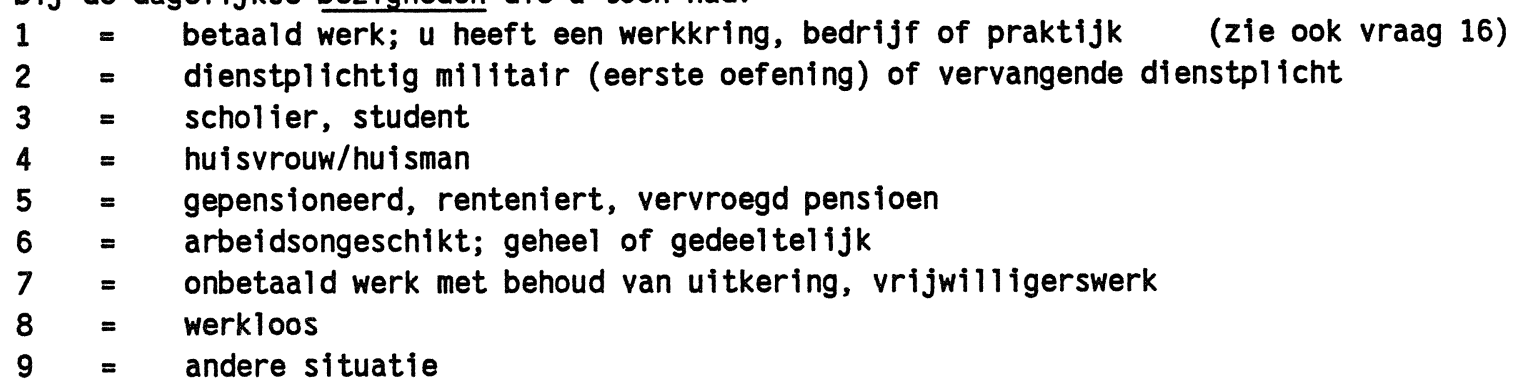

Vraag 19: Bent $u$ in de afgelopen 12 maanden van functie veranderd?

$$
\begin{aligned}
& 1=\text { ja } \\
& 2=\text { nee }
\end{aligned}
$$

Vraag 20: Bent $u$ in de afgelopen 12 maanden van werkgever veranderd?

$$
\begin{aligned}
& 1=\text { ja } \\
& 2=\text { nee }
\end{aligned}
$$

Vraag 21: Op welke wijze heeft u uw huidige functie verworven? Vul het juiste codenummer in. $U$ kunt slechts één codenummer invullen.

$01=$ sollicitatie op advertentie
$02=$ via familie, vrienden of relaties
$03=$ via medewerkers Faculteit der Gezondheidswetenschappen
$04=$ via stagecontacten
$05=$ via het arbeidsbureau
$06=$ via een uitzendbureau
$07=$ via een wervingsorganisatie (head-hunting)
$08=$ via vrijwilligerswerk
$09=$ zelf gevraagd bij werkgever (open sollicitatie)
$10=$ zelf advertentie geplaatst
$11=$ werd benaderd door werkgever
$12=$ voor mezelf begonnen
$13=$ andere wijze

Vraag 22: In welk dienstverband bent $u$ thans werkzaam?

1 = werkzaam in loondienst

2 = werkzaam als zelfstandige voor eigen rekening of risico (eigen bedrijf of free-lance)

3 = werkzaam in een gezinsbedrijf; niet in loondienst

Vraag 23: Vul het totaal aantal maanden in waarop uw aanstelling betrekking heeft. Diegenen die een aanstelling hebben van meer dan 5 jaar noteren codenummer 99.

Vraag 24: Hoeveel uren per week werkt u gewoonlijk? Noteer het (gemiddelde) aantal arbeidsuren. Laat de uren door overwerk en voor nevenfuncties buiten beschouwing.

Vraag 25: Op het inlegvel vindt u een schema van beroepsgroepen zoals die door het CBS worden gehanteerd. Binnen een hoofdcategorie vindt $u$ de naam van een bepaalde beroepsgroep, het betreffende codenummer en enkele voorbeelden van beroepen die tot deze beroepsgroep behoren. Vul op de basisvragenkaart het codenummer in dat het beste past bij uw werkzaamheden in uw huidige functie.

Vraag 26: Noteer de naam van uw huidige functie op de aangegeven lijn. 
Vraag 27: Aan hoeveel mensen geeft $u$, binnen de organisatie waar $u$ werkzaam bent, leiding? Noteer het juiste codenummer.
0 = geen leiding aan andere personen
1 = leiding aan $1-4$ personen
$2=$ leiding aan 5 - 9 personen
$3=1$ leiding aan $10-19$ personen
$4=1$ leiding aan $20-49$ personen
$5=$ leiding aan 50 of meer personen

Vraag 28: Hoeveel bedraagt uw bruto inkomen per maand in uw huidige functie bij een volledige werkweek (exclusief toeslagen voor overwerk, 13e maand en vakantie)? Vul het codenummer van de betreffende categorie in.

$1=$ minder dan $f 1.500,--$
$2=$ f $1.500,--$ tot $f 2.000, \ldots$
$3=$ f $2.000,--$ tot $f 2.500, \ldots$
$4=$ f $2.500,--$ tot $f 3.000, \ldots$
$5=$ f $3.000,--$ tot $f 3.750,--$
$6=$ f $3.750,--$ tot $f 5.000,--$
$7=$ f $5.000,--$ tot $f 7.500,--$
$8=$ f $7.500,--$ tot $f 12.500,--$
$9=$ f $12.500,--$ of meer

Vraag 29: In wat voor een soort instelling, praktijk of bedrijf bent $u$ thans werkzaam? Op het inlegvel vindt u een schema van branchegroepen zoals die door het CBS worden gehanteerd. Binnen een hoofdcategorie vindt $u$ de naam van een bepaalde branchegroep en het betreffende codenummer. Vul op de basisvragenkaart het codenummer in dat het beste past bij de diensten, c.q. produkten die door de instelling, de praktijk of het bedrijf waar $u$ werkzaam bent worden geleverd.

Vraag 30: Noteer naam en adres van de instelling, de praktijk of het bedrijf waar of van waaruit u werkt. Het gaat om de vestiging waar $u$ werkzaam bent.

Vraag 31: Noteer op de aangegeven lijn de belangrijkste dienst/produkt die door de instelling, de praktijk of het bedrijf waar $u$ werkzaam bent, wordt geleverd.

Vraag 32: Hoeveel mensen werken er bij uw instelling, praktijk of bedrijf? Althans voor zover in de vestiging waar u werkzaam bent.

$1=$ minder dan 10 personen
$2=10$ tot en met 49 personen
$3=50$ tot en met 99 personen
$4=100$ personen of meer

De volgende vragen zijn bedoeld voor iedereen.

Vraag 33: Heeft $u$ in de afgelopen 4 weken naar een baan voor uzelf gezocht? Zo ja, op welke wijze(n)? Vul juiste codenummer(s) in. Er zijn maximaal 6 antwoorden mogelijk.
$00=$ zoekt (nog) geen (ander) werk
$01=$ nazoeken van personeels-advertenties
$02=$ reageren op advertenties
$03=$ zelf plaatsen van advertenties
$04=$ zelf gevraagd bij werkgevers (open sollicitatie)
$05=$ via familie, vrienden of relaties
$06=$ via medewerkers Faculteit der Gezondheidswetenschappen
$07=$ via stagecontacten
$08=$ via het arbeidsbureau
$09=$ via een uitzendbureau
10 = via een wervingsorganisatie (head-hunting)
11 = terug naar vorige werkkring
12 = opzetten eigen bedrijf, voor zichzelf beginnen
13 = via vrijwilligerswerk
$14=$ op andere wijze 
Vraag 34: Als u nu een (meer) geschikte baan zou vinden, kunt u dan binnen 2 weken beginnen?

$\begin{array}{lll}1 & = & \text { ja } \\ 2 & = & \text { nee }\end{array}$

Vraag 35: Heeft $u$ in de afgelopen 12 maanden een opleiding gevolgd? Indien $u$ meerdere opleidingen heeft gevolgd, noteert $u$ de aard, de richting en de naam van de opleiding met het grootste aantal lesuren. De aard en de richting kunt $u$ invullen aan de hand van de volgende codenummers. Indien $u$ in de afgelopen 12 maanden géén opleiding heeft gevolgd, vul dan voor de aard het cijfer $\underline{0}$ en voor de richting de cijfers $\underline{00}$ in.

aard:

$\begin{array}{ll}\overline{1} & =\text { middelbaar beroepsonderwijs (voltijd) } \\ 2 & =\text { hoger beroepsonderwijs (voltijd) } \\ 3 & =\text { wetenschappelijk onderwijs (voltijd) } \\ 4 & =\text { middelbare deeltijdopleiding } \\ 5 & =\text { hogere deeltijdopleiding } \\ 6 & =\text { wetenschappelijke deeltijdopleiding } \\ 7 & =\text { een ander soort opleiding }\end{array}$

richting:

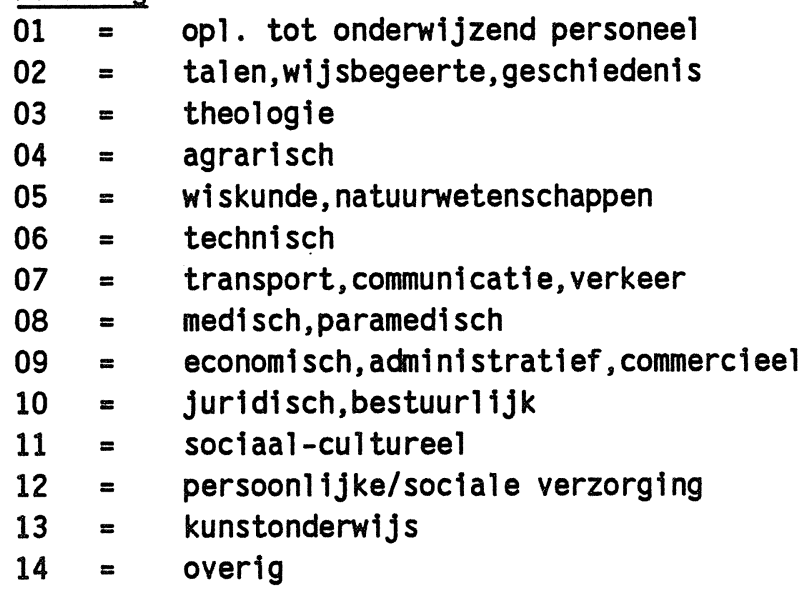

Vraag 36: Hieronder staan enkele activiteiten die voor afgestudeerden van de Rijksuniversiteit Limburg (mogelijk) worden georganiseerd. Voor welke van onderstaande activiteiten heeft $u$ belangstelling? $U$ kunt meerdere codenummers noteren.

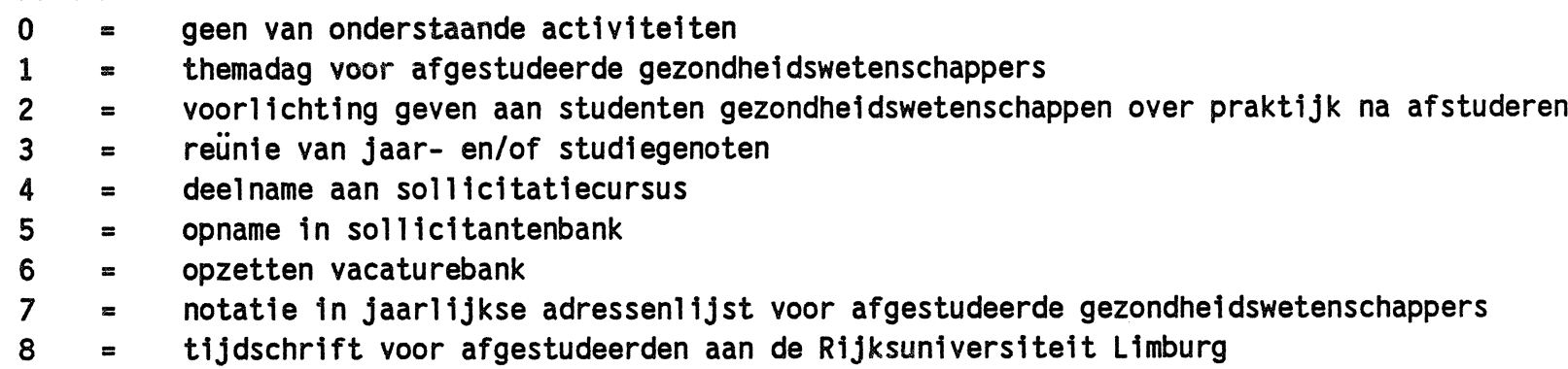

Vraag 37: Wenst u een samenvattend verslag van het onderzoek te ontvangen?

$\begin{array}{ll}1 & =j a \\ 2 & =\end{array}$


BEDRIJFSKUNDIGEN

028

TECHNICI

029

051

052

054

061

069

071

076

079

081

083

084

085

090

110

129

131

BELEIDVOERING EN LEIDINGGEVING NIET OPENBAAR BESTUUR
BELEIDVOERING EN LEIDINGGEVING OPENBAAR BESTUUR

hogere technische speclall saties n.e.g.

BIOLOGEN / BIOCHEMICI / LANDBOUKUNDIGEN

blologen, zoölogen, botanici

blochemicl, bacterfologen, farmacologen

botanische, medische analisten

GENEESKUNDIGE VAKSPECIALISTEN

diëtisten, voedingsdeskundigen

verpleegkundigen

fysio-, arbeidstherapeuten

overige (para)medische functies

hogere statistici

statistische en wiskundige assistenten

ECONOMEN

$$
\text { economen }
$$

ACCOUNTANTS

accountants

JURISTEN

DOCENTEN

docent

hoof den scholen a. onderwijsk. functies

WETENSCHAPPELIJKE EN ANDERE VAKSPECIALISTEN

soclale wetenschapsbeoefenaren

maatschappelifke en culturele werkers

personeels-, beroepenspecial isten

overige vakspecialisten

hoof damb tenaren beleidvoerend/leidinggevend geneeskundigen

directeuren n.v., coöperatie, stichting, vereniging, overheldsbedrijf

zelfstandige bedrijfshoofden

bedrijfsleiders aigemene leiding

bedrijfsleiders produktie

overige hogere leidinggevende functies

ADMINISTRATIEVE FUNCTIES

toezichthoudend administratief personeel

ultvoerende hoof dambtenaren

calculators, bankemployés, boekhouders

correspondenten

COMMERCIELE FUNCTIES

technische vertegenwoordigers

verzekeringsagenten, commissionairs o.d.

vellinghouders, taxateurs

DIENSTVERLENENDE FUNCTIES

toezichthoudend hul shoudel ijk personeel

verzorgend personeel

doktersassistenten $\mathbf{c}$.d.

ANDERE BEROEPSGROEP

overige beroepsgroepen
STATISTICI / AUTOMATISERINGSDESKUNDIGEN

automati seringsdeskundigen

computerdeskundigen

organisatie-adviseur, arbeidsanalist, bedrijfshygiënist

voedingsmiddel entechnoloog, hoger technisch adviseur

ecoloog

toxicoloog, immunoloog, epldemioloog, klinisch chemicus

klinisch laborant, medisch analist

revalidatiearts, psychiater, allergoloog, bedriffsarts, (sport)medisch adviseur, adviseur ill leuhyglëne

voedingsadviseur / -voorlichter

hoofd verpleegaf deling, docent-verpleegkundige

bewegings-, bezigheidstherapeut, revalidatieassistent

inspecteur volksgezondheid, clinical trial manager

medisch statisticus

systeemanalisten, hoofd / organisatieadviseur automatisering programmeurs

assistent medisch statisticus

bedriffseconoom, sociaal-economisch onderzoeker / adviseur

bedriffsaccountant, financleel-economisch medewerker

juridisch medewerker/adviseur, verzekerings/bedrijfsjurist

docent gezondheidsleer / epidemiologie / gezinssociologie hoofd onderwijsinstelling, onderwijsk.adviseur/onderzoeker

bedrijfssocfoloog / -psycholoog, psychotechnicus, andragoog medisch/bedriffsmaatschappelifk werker, GVO-functionaris personeels-adviseur / -functionaris, hoofd personeelszaken wetenschappelijk medewerker (excl. technisch), verzekeringsdeskundige, economisch-huishoudelijk voorlichter

directeur overheidsdienst, medewerker voorbereiding beleid (niet uitvoerend), staffunctionaris directeur ziekenhuis / farmaceutisch bedrijf bedriffshoofd vestiging multinational

manager algemene leiding (industriële bedriffstak)

manager produktie farmaceutische industrie

hoofd afdeling, zlekenhuiseconoom, staffunctionaris

hoofd secretarfaat

medewerker uitvoering beleid

accountmanager

controleur polisbescheiden / bedrijfsvereniging

artsenbezoeker

verzekeringsinspecteur, verzekeringsadviseur

verzekeringsexpert

hoofd huishoudelijke en civiele dienst

gezinsverzorgende, bejaardenhulp

secretaresse, trainer, detallilist, in-/verkoper doktersassistent 
0000

2000

2100

2700

2800

2900

3600

6000

6800

8100

8200

8400

9010

9070

9230

9240

9250

9260

9270

9310

9320

9330

9340

9831

9382

9383

9384

9385

9386

9387

9390

9410

9420

9430

9440

9450

9460

9470

9510

9520

9530

9540

9590

9690

9710

9720

9730

9740

9750

9790

LANDBOUW EN VISSERIJ

INDUSTRIE

landouw en visserij

voedingsindustrie

genotmiddel enindustrie

grafische industrie en uitgeverijen

aardolie-industrie

chemische industrie

electrotechnische industrie

HANDEL \& REPARATIEBEDRIJVEN VOOR GEBRUIKSGOEDEREN

handel

reparatiebedrijven voor gebruiksgoederen

BANK - \& VERZEKERINGSWEZEN \& ZAKELIJKE DIENSTVERLENING

bankwezen

verzekeringswezen

zakelijke dienstverlening

OPENBAAR BESTUUR \& DEFENSIE \& WETTELIJKE SOCIALE VERZEKERING

algemene overheidsadministraties

wettelijke sociale verzekering, ziekenfondsen

ONDERWIJS

buitengewoon onderwijs

algemeen voortgezet onderwijs

lager en middelbaar beroepsonderwijs

hoger beroepsonderwijs

wetenschappelijk onderwijs

GEZONDHEIDS- EN VETERINAIRE DIENSTEN

algemene en gespecialiseerde ziekenhuizen (exc. psychiatrisch) \& klinieken

psychiatrische inrichtingen en bijzondere psychiatrische kifnieken

zwakzinnigeninrichtingen; gezinsvervangende tehuizen

verpleeghuizen

medische en verpleegkundige diensten

paramedische instituten en praktijken

medische dag- en nachtverblijven voor lichamelijk gehandicapten

medische dag- en nachtverblijven voor psychisch en/of meervoudig gehandicapten

poliklinieken; anders dan ziekenhuizen

medische labaratoria

overkoepelende samenwerkings- en adviesorganen \& fondsen op medisch gebied

veterinaire diensten

MAATSCHAPPELIJKE DIENSTVERLENING

bejaardentehuizen; woonvoorzieningen voor bejaarden

kindertehuizen, sociale tehuizen voor niet-gehandicapten

tehuizen en dagverblijuen voor gehandicapten; geen medische behandeling

sociaal-medische, sociaal-psychologische en sociaal-pedagogische diensten

algemeen maatschappelijke organisaties

gezinsverzorging en gezinshulp

consumentenvoorlichtings- on gezinsdiensten (kinderdagverblifven, creches)

SOCIAAL-CULTURELE EN CULTURELE INSTELLINGEN

buurt - en clubhuiswerk en samenlevingsopbouwwerk

jeugd- en jongerenwerk

vormingswerk (bulten schoolverband)

bibllotheken, musea en cultuurbehoud en bijbehorende verenigingen, stichtingen

sociaal-culturele en culturele samenwerkings- en adviesorganen \& fondsen op dit gebied

SPORT EN RECREATIE

overkoepelende samenwerkings- en adviesorganen op het gebied van sporten recreatie

BEDRIJFS- EN WERKNEMERSORGANISATIES, RESEARCHINSTELLINGEN, OVERIGE SOCIALE ORGANISATIES publiekrechtelifke bedrijfsorganen

werkgevers- en ondernemersorganisaties

werknemersorganisaties

beroepsorganisaties

research- en wetenschappelijke instellingen en fondsen (excl. universiteiten, hogescholen) overige sociale organisaties 
Geachte mevrouw/mijnheer,

Zoals $u$ zich wellicht kunt herinneren bent $u$ vorig jaar benaderd om een kaart met gegevens in te vullen ten behoeve van het periodieke loopbaanonderzoek onder afgestudeerden van de Rijksuniversiteit Limburg (RL). Ook dit jaar zouden wij uw medewerking aan deze jaarlijkse enquête op prijs stellen.

In dit loopbaanonderzoek werken de afzonderlijke faculteiten samen met het Researchcentrum voor Onderwijs en Arbeidsmarkt (ROA) van de RL. Het ROA is verbonden aan de Faculteit der Economische Wetenschappen van de RL. De coördinatie van dit onderzoekproject is voorlopig in handen van het ROA. Op termijn wordt echter gestreefd naar een onafhankelijke stichting. Deze stichting zal de universiteit behulpzaam zijn bij het ontplooien van activiteiten ten behoeve van afgestudeerden aan de RL. Als u wilt deelnemen aan deze activiteiten kunt $u$ dat op de jaarkaart aangeven.

De door $u$ op de jaarkaart ingevulde gegevens zullen anoniem voor het bovengenoemde loopbaanonderzoek worden gebruikt.

De ingevulde jaarkaart kunt $u$ in de bijgevoegde antwoordenveloppe zonder postzegel sturen naar het ROA. Liefst zo snel mogelijk. Over enkele maanden zal een samenvattend verslag van het loopbaanonderzoek verschijnen. Indien $u$ daarvoor belangstelling heeft kunt $u$ dit kenbaar maken op de jaarkaart. Meer informatie kunt $u$ krijgen bij dhr. G. Ramaekers, ROA, Postbus 616, 6200 MD Maastricht, telefoon $043-888852$.

We hopen dat u opnieuw mee wil werken door de jaarkaart in te vullen en op te sturen. Alvast hartelijk dank en veel succes in uw verdere toekomst.

\section{INSTRUCTIES VOOR HET INVULLEN VAN DE VRAGEN}

Lees eerst onderstaande instructies, voordat $u$ de vragen gaat beantwoorden!

De enquête bestaat uit een jaarkaart en een bijbehorende toelichting op de vragen. Alle antwoorden noteert u alléén op de jaarkaart. Lees bij ledere vraag eerst de bijbehorende toelichting. Noteer daarna het antwoord. Deze toelichting heeft $u$ nodig om te weten welke codenummers $u$ bij het invullen van de jaarkaart dient te gebruiken.

Een aantal antwoorden op de jaarkaart is reeds voorgedrukt aan de hand van gegevens uit voorafgaande jaren. Alleen gegevens die niet, onvolledig of onjuist zijn genoteerd, dient $u$ uitsluitend in de daarvoor bestemde hokjes in te vullen. Noteer de antwoorden altijd in blokletters en neem codenummers uit de toelichting bij de vragen nauwkeurig over. De verwerking van de jaarkaarten gaat dan veel vlotter.

ALVAST HARTELIJK DANK VOOR UW MEDEWERKING! 
Onderstaande gegevens hebben alleen betrekking op het afgelopen jaar Alleen imulien indien gcoevens niet, onfuist of onvolledig ziln voorectrukt!

1. naam:

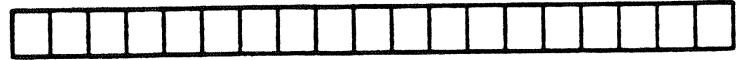

2. voorletters:

3. straatnaam:

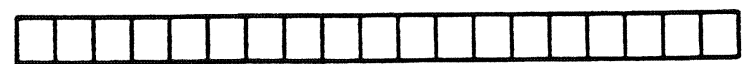

4. huis snummer:



5. woonplaats:

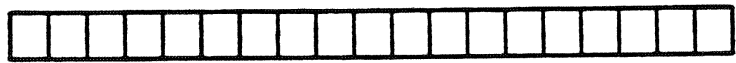

6. postcode:

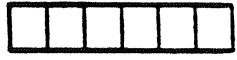

7. land:

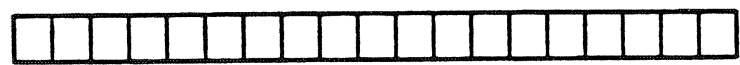

8. telefoon:

9. gepromoveerd:

10. muldige situatie:

11. werkzoekend: $\square$

12. bezigheden april t/m mart 1989:

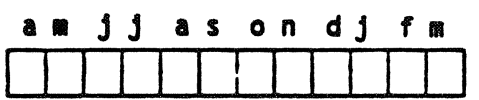

Mlet elke vraes hooft voor y relevant te ziln (zle toollenting)

13. verandering functie:

1E. Punetiewerving:

17. IIjdsdur anstelling:

19. beroepsgroep:

21. Ielding:

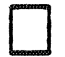

14. verandering werkgever:

16. dienstverband:

18. arbeldsuren:

20. Punctienaam:

22. Inkomen:

23. branehegroep:

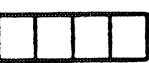

24. dienst/produkt:

25. naam $\downarrow$ workadres:

26. personeel soevang:

$\square$

27. Werkzokkethod (n):

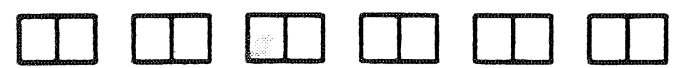

28. beschilbaarheid:

29. opleiding: ard: $\square$ riehting: $\square \square$ nata:

30. deeiname aktivitelten:

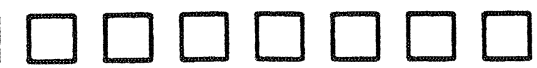

31. versiag ondorzoek: 
ALLEEN DE ANTWOORDEN DIE NIET, ONJUIST OF ONVOLLEDIG ZIJN VOORGEDRUKT INVULLEN! GEBRUIK UITSLUITEND DE DAARVOOR BESTEMDE HOKJES.

Vraag 1: Gehuwde vrouwen dienen hier alleen hun meisjesnaam te vermelden.

Vraag 8: Plaats tussen netnummer en abonneenummer een liggend streepje (-).

Vraag 9: Bent u gepromoveerd tot dr.?

$1=j a$

$2=$ nee

Vraag 10: Deze vraag betreft uw huidige situatie. Als u onderstaande mogelijkheden bekijkt, waartoe rekent u zich dan? Vul het codenummer in dat het beste past bij uw huidige situatie. $U$ kunt slechts éen codenummer invulien.

1 = betaald werk; u heeft werkkring, bedrijf of praktijk

- werkt in loondienst

- werkt voor eigen rekening of risico

- werkt als gezinslid mee in het bedrijf van echtgenoot/ouders

- werkt op een sociale werkplaats of aanvullende werken

- in opleiding bij een bedrijf of instelling maar met loon of salaris

- stagiair met loon of salaris

2 = dienstplichtig militair (eerste oefening) of vervangende dienstplicht

$3=$ scholier, student

$4=$ huisvrouw/huisman

$5=$ gepensioneerd, renteniert, vervroegd pensioen

6 = arbeidsongeschikt; geheel of gedeeltelijk

7 = onbetaald werk met behoud van uitkering, vrijwilligerswerk

$8=$ werkloos

$9=$ andere situatie

Bij codenummer 1 gaat $u$ na het beantwoorden van vraag 11 en 12 verder met vraag 13; indien u meer dan één baan heeft, hebben de vragen 13 tot en met 26 alléén betrekking op de baan met de meeste arbeidsuren.

Bij de overige codenummers gaat $u$ na het beantwoorden van vraag 11 en 12 verder met vraag 27.

Vraag 11: Bent u op zoek naar een (andere baan) voor uzelf?

$\begin{array}{lll}1 & = & \text { ja } \\ 2 & =\text { nee }\end{array}$

Vraag 12: Noteer voor iedere maand in de periode april $1988 \mathrm{t} / \mathrm{m}$ maart 1989 het codenummer dat het beste past bij de dagelijkse bezigheden die $u$ toen had.

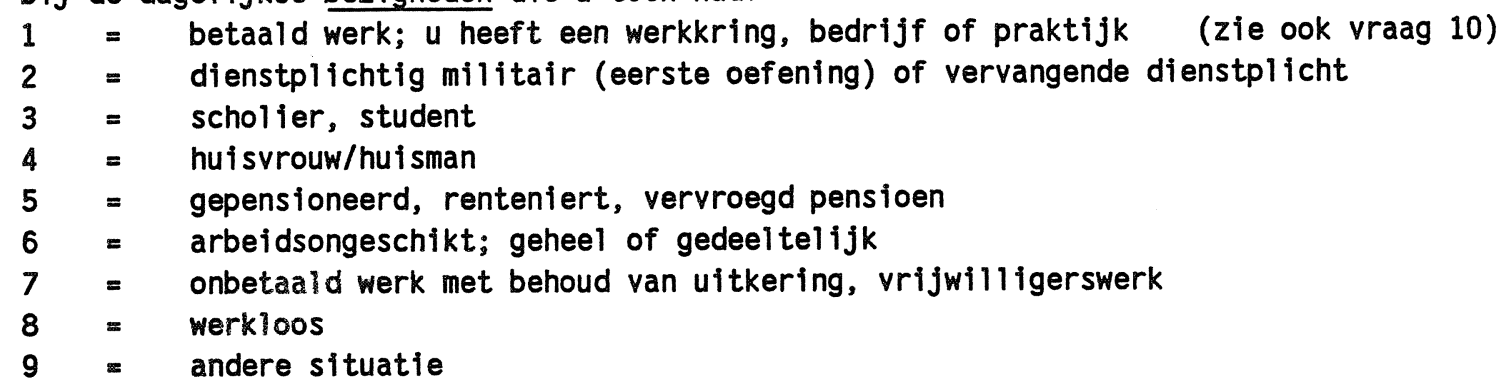

Vraag 13: Bent $u$ in de afgelopen 12 maanden van functie veranderd?

$$
\begin{aligned}
& 1=\text { ja } \\
& 2=\text { nee }
\end{aligned}
$$

Vraag 14: Bent $u$ in de afgelopen 12 maanden van werkgever veranderd?

$$
\begin{aligned}
& 1=\text { ja } \\
& 2=\text { nee }
\end{aligned}
$$


Vraag 15: Op welke wijze heeft $u$ uw huidige functie verworven? Vul het juiste codenummer in. $U$ kunt slechts één codenummer invulien.

$01=$ sollicitatie op advertentie
$02=$ via familie, vrienden of relaties
$03=$ via medewerkers Faculteit der Gezondheidswetenschappen
$04=$ via stagecontacten
$05=$ via het arbeidsbureau
$06=$ via een uitzendbureau
$07=$ via een wervingsorganisatie (head-hunting)
$08=$ via vrijwilligerswerk
$09=$ zelf gevraagd bij werkgever (open sollicitatie)
$10=$ zelf advertentie geplaatst
$11=$ werd benaderd door werkgever
$12=$ voor mezelf begonnen
$13=$ op andere wijze

Vraag 16: In welk dienstverband bent $u$ thans werkzaam?

$1=$ werkzaam in loondienst

2 = werkzaam als zelfstandige voor eigen rekening of risico (eigen bedrijf of free-lance)

$3=$ werkzaam in een gezinsbedrijf; niet in loondienst

Vraag 17: Vul het totaal aantal maanden in waarop uw huidige aanstelling betrekking heeft. Diegenen die een aanstelling hebben van meer dan 5 jaar noteren codenummer 99.

Vraag 18: Hoeveel uren per week werkt u gewoonlijk? Noteer het (gemiddelde) aantal arbeidsuren. Laat de uren door overwerk en voor nevenwerkzaamheden buiten beschouwing.

Vraag 19: Op het inlegvel vindt $u$ een schema van beroepsgroepen zoals die door het CBS worden gehanteerd. Binnen een hoofdcategorie vindt $u$ de naam van een bepaalde beroepsgroep, het betreffende codenummer en enkele voorbeelden van beroepen die tot deze beroepsgroep behoren. Vul op de jaarkaart het codenummer in dat het beste past bij uw werkzaamheden in uw huidige functie.

Vraag 20: Noteer de naam van uw huidige functie op de aangegeven iijn.

Vraag 21: Aan hoeveel mensen geeft u, binnen de organisatie waar u werkzaam bent, leiding? Noteer het juiste codenummer.

$0=$ geen leiding aan andere personen
$1=$ leiding aan $1-4$ personen
$2=1$ leiding aan $5-9$ personen
$3=$ leiding aan $10-19$ personen
$4=1$ leiding aan $20-49$ personen
$5=$ leiding aan 50 of meer personen

Vraag 22: Hoeveel bedraagt uw bruto inkomen per maand in uw huidige functie bij een volledige werkweek (exclusief toeslagen voor overwerk, 13e maand en vakantie)? Vul het codenummer van de betreffende categorie in.

$1=$ minder dan $f 1.500, \ldots$
$2=f 1.500, \ldots$ tot $f 2.000, \ldots$
$3=f 2.000, \ldots$ tot $f 2.500, \ldots$
$4=f 2.500, \ldots$ tot $f 3.000, \ldots$
$5=f 3.000, \ldots$ tot $f 3.750, \ldots$
$6=f 3.750, \ldots$ tot $f 5.000, \ldots$
$7=$ f $5.000, \ldots$ tot $f 7.500, \ldots$
$8=$ f $7.500, \ldots$ tot $f 12.500, \ldots$
$9=$ f $12.500, \ldots$ of meer

Vraag 23: In wat voor een soort instelling, praktijk of bedrijf bent $u$ thans werkzaam? Op het inlegvel vindt $u$ een schema van branchegroepen zoals die door het CBS worden gehanteerd. Binnen een hoofdcategorie vindt $u$ de naam van een bepaal de branchegroep en het betreffende codenummer. Vul op de jaarkaart het codenummer in dat het beste past bij de diensten, c.q. produkten die door de instelling, de praktijk of het bedrijf waar $u$ werkzaam bent worden geleverd.

Vraag 24: Noteer op de aangegeven lijn de belangrijkste dienst/produkt die door de instelling, de praktijk of het bedrijf waar $u$ werkzaam bent wordt geleverd. 
Vraag 25: Noteer naam en adres van de instelling, de praktijk of het bedrijf waar of van waaruit $u$ werkt. Het gaat om de vestiging waar $u$ werkzaam bent.

Vraag 26: Hoeveel mensen werken er bij uw instelling, praktijk of bedrijf? Althans voor zover in de vestiging waar u werkzaam bent.

$1=$ minder dan 10 personen
$2=10$ tot en met 49 personen
$3=50$ tot en met 99 personen
$4=100$ personen of meer

De volgende vragen zijn bedoeld voor iedereen.

Vraag 27: Heeft $u$ in de afgelopen 4 weken naar een baan voor uzelf gezocht? Zo ja, op welke wijze(n)? Vul juiste codenummer(s) in. Er zijn maximaal 6 antwoorden mogelijk.



Vraag 28: Als u nu een (meer) geschikte baan zou vinden, kunt u dan binnen 2 weken beginnen?

$$
\begin{aligned}
& 1=j a \\
& 2=\text { nee }
\end{aligned}
$$

Vraag 29: Heeft $u$ in afgelopen 12 maanden een opleiding gevolgd? Indien u meerdere opleidingen heeft gevolgd, noteert $u$ de aard, de richting en de naam van de opleiding met het grootste aantal lesuren. De aard en de richting kunt $u$ invullen aan de hand van de volgende codenummers. Indien $u$ in de afgelopen 12 maanden géén opleiding heeft gevolgd, vul dan voor de aard het cijfer $\underline{0}$ en voor de richting de cijfers 00 in.

aard:

$\begin{array}{ll}1 & =\text { middelbaar beroepsonderwijs (voltijd) } \\ 2 & =\text { hoger beroepsonderwijs (voltijd) } \\ 3 & =\text { wetenschappelijk onderwijs (voltijd) } \\ 4 & =\text { middelbare deeltijdopleiding } \\ 5 & =\text { hogere deeltijdopleiding } \\ 6 & =\text { wetenschappelijke deeltijdopleiding } \\ 7 & =\text { een ander soort opleiding }\end{array}$




Vraag 30: Hieronder staan enkele activiteiten die voor afgestudeerden van de Rijksuniversiteit Limburg (mogelijk) worden georganiseerd. Voor welke van onderstaande activiteiten heeft $u$ belangstelling? $U$ kunt meerdere codenummers noteren.

$0=$ geen van onderstaande activiteiten

$1=$ themadag voor afgestudeerde gezondheidswetenschappers

2 = voorlichting geven aan studenten gezondheidswetenschappen over praktijk na afstuderen

$3=$ reünie van jaar-en/of studiegenoten

4 = deelname aan sollicitatiecursus

$5=$ opname in sollicitantenbank

$6=$ opzetten vacaturebank

7 = notatie in jaarlijkse adressenlijst voor afgestudeerde gezondheidswetenschappers

$8=$ tijdschrift voor afgestudeerden aan de Rijksuniversiteit Limburg

Vraag 31: Wenst $u$ een samenvattend verslag van het onderzoek te ontvangen?

$1=j a$

$2=$ nee 
BEDRIJFSKUNDIGEN

028

$$
\text { bedrijfskundigen }
$$

TECHNICI

\section{BIOLOGEN / BIOCHEMICI / LANDBOUKUNDIGEN}

051

BELEIDVOERING EN LEIDINGGEVING OPENBAAR BESTUUR

\section{BELEIDVOERING EN LEIDINGGEVING NIET OPENBAAR BESTUUR}

diëtisten, voedingsdeskundigen verpleegkundigen

fysio-, arbeidstherapeuten

overige (para)medische functies

STATISTICI / AUTOMATISERINGSDESKUNDIGEN

hogere statistici

automati seringsdeskundigen

computerdeskundigen

statistische en wiskundige assistenten ECONOMEN

ACCOUNTANTS

JURISTEN

DOCENTEN

docent

hoof den scholen a.a. onderwijsk. functies WETENSCHAPPELIJKE EN ANDERE VAKSPECIALISTEN sociale wetenschapsbooefenaren maatschappelijke en culturele werkers personeels-, beroepenspecialisten overige vakspecialisten directeuren n.v., cooperatie, stichting, vereniging, overheidsbedrijf zelf standige bedrijf shoofden bedrijfsleiders algemene lefding bedrijfsleiders produktie overige hogere leidinggevende functies ADMINISTRATIEVE FUNCTIES toezichthoudend administratiof personeel ultvoerende hoof dambtenaren calculators, bankemployés, boekhouders correspondenten

COMERCIELE FUNCTIES

\section{technische vertegenwoordigers} verzekeringsagenten, commissionairs o.d. vellinghouders, taxateurs

DIENSTVERLENENDE FUNCTIES toezichthoudend huishoudel ifk personeel verzorgend personeel doktersassistenten e.d. ANDERE BEROEPSGROEP overige beroepsgroepen organisatie-adviseur, arbeidsanalist, bedrijfshyglënist

voedingsmiddelentechnoloog, hoger technisch adviseur

ecoloog

toxicoloog, immunoloog, epidemioloog, klinisch chemicus klinisch laborant, medisch analist

revalidatiearts, psychiater, allergoloog, bedrijfsarts, (sport)medisch adviseur, adviseur milleuhyglëne voedingsadviseur / -voorlichter hoofd verpleegaf deling, docent-verpleegkundige bewegings-, bezigheidstherapeut, revalidatieassistent inspecteur volksgezondheid, clinical trial manager

medisch statisticus

systeemanalisten, hoofd / organisatleadviseur automatisering programeurs

assistent medisch statisticus

bedrijfseconoom, sociaal-economisch onderzoeker / adviseur

bedriffsaccountant, financieel-economi sch medewerker

Juridisch medewerker/adviseur, verzekerings/bedrijfsjurist

docent gezondheidsleer / epidemiologie / gezinssociologie hoofd onderwijsinstelling, onderwijsk.adviseur/onderzoeker

bedriffssocioloog / -psycholoog, psychotechnicus, andragoog medisch/bedrijf smaatschappel ijk werker, GVo-functionaris personeels-adviseur / -functionaris, hoofd personeelszaken wetenschappelijk medewerker (excl. technisch), verzekeringsdeskundige, economisch-huishoudelijk voorlichter

directeur overheidsdienst, medewerker voorbereiding beleid (niet uitvoerend), staffunctionaris

directeur ziekenhuls / farmaceutisch bedrijf bedrijfshoofd vestiging multinational manager algemene leiding (industriële bedrijfstak) wanager produktie farmaceutische industrie hoofd afdeling, zlekenhuiseconoom, staffunctionaris

hoofd secretarlaat

nedewerker uitvoering beleid

accountmanager

controleur polisbescheiden / bedriffsvereniging

artsenbezoeker

verzekeringsinspecteur, verzekeringsadviseur verzekeringsexpert

hoofd huishoudelijke en civiele dienst gezinsverzorgende, bejaardenhulp doktersassistent

secretaresse, trainer, detallilst, In-/verkoper 
0000

2000

2100

2700

2800

2900

3600

6000

6800

8100

8200

8400

9010

9070

9230

9240

9250

9260

9270

9310

9320

9330

9340

9831

9382

9383

9384

9385

9386

9387

9390

9410

9420

9430

9440

9450

9460

9470

9510

9520

9530

9540

9590

9690

9710

9720

9730

9740

9750

9790

LANDBOUW EN VISSERIJ

INDUSTRIE

landbouw en visserij

voedingsindustrie

genotmiddelenindustrie

grafische industrie en uitgeverijen

aardolie-industrie

chemische industrie

electrotechnische industrie

HANDEL \& REPARATIEBEDRIJVEN VOOR GEBRUIKSGOEDEREN

handel

reparatiebedrijven voor gebruiksgoederen

BANK - \& VERZEKERINGSWEZEN \& ZAKELIJKE DIENSTVERLENING

bankwezen

verzekeringswezen

zakelijke dienstverlening

OPENBAAR BESTUUR \& DEFENSIE \& WETTELIJKE SOCIALE VERZEKERING

algemene overheidsadministraties

wettelijke sociale verzekering, ziekenfondsen

ONDERWIJS

buitengewoon onderwijs

algemeen voortgezet onderwijs

lager en middelbaar beroepsonderwijs

hoger beroepsonderwijs

wetenschappelijk onderwijs

GEZONDHEIDS- EN VETERINAIRE DIENSTEN

algemene en gespecialiseerde ziekenhuizen (exc. psychiatrisch) \& klinieken

psychiatrische inrichtingen en bijzondere psychiatrische klinieken

zwakzinnigeninrichtingen; gezinsvervangende tehuizen

verpleeghuizen

medische en verpleegkundige diensten

paramedische instituten en praktijken

medische dag- en nachtverblifjen voor lichamelijk gehandicapten

medische dag- en nachtverblijven voor psychisch en/of meervoudig gehandicapten

polikilinieken; anders dan ziekenhuizen

medische labaratoria

overkoepelende samenwerkings- en adviesorganen \& fondsen op medisch gebied

veterinaire diensten

MAATSCHAPPELIJKE DIENSTVERLENING

bejaardentehuizen; woonvoorzieningen voor bejaarden

kindertehuizen, sociale tehuizen voor niet-gehandicapten

tehuizen en dagverblijven voor gehandicapten; geen medische behandeling

sociaal-medische, sociaal-psychologische en sociaal-pedagogische diensten

algemeen maatschappelijke organisaties

gezinsverzorging en gezinshulp

consumentenvoorlichtings- en gezinsdiensten (kinderdagverblijven, creches)

SOCIAAL-CULTURELE EN CULTURELE INSTELLINGEN

buurt- en clubhuiswerk en samenlevingsopbouwwerk

jeugd- en jongerenwerk

vormingswerk (buiten schoolverband)

bibliotheken, musea en cultuurbehoud en bijbehorende verenigingen, stichtingen

sociaal-culturele en culturele samenwerkings- en adviesorganen \& fondsen op dit gebied

SPORT EN RECREATIE

overkoepelende samenwerkings- en adviesorganen op het gebied van sporten recreatie

BEDRIJFS- EN WERKNEMERSORGANISATIES, RESEARCHINSTELLINGEN, OVERIGE SOCIALE ORGANISATIES

publiekrechtelijke bedrijf sorganen

werkgevers- en ondernemersorganisaties

werknemersorganisaties

beroepsorganisaties

research- en wetenschappelijke instellingen en fondsen (excl. universiteiten, hogescholen)

overige sociale organisaties 
Evaluatie-formulier behorend bij de concept-jaarkaart voor afgestudeerden FoGW/RL

versie 8803.4

\section{Handlelding voor dit evaluatie-formulfer:}

1. Lees eerst dit onderstaande evaluatie-formulfer globaal door, zodat u vast weet op welke punten u straks moet letten bif het doornemen van de vragen.

2. Als bepaalde facetten van de concept-jaarkaart, de daarbij horende toelichting of de begeleidende brief, niet in het evaluatie-formulier aan de orde komen, maar waarvan $u$ vindt dat die in cen definitieve versie anders zouden moten zijn, arzel dan niet om daarvan melding te maken!

3. Dit evaluatie-formulier bestaat uit twee 'vragen-blokken': eén over de begeleidende brief met de instrukties en éen over de jaarkaart en bijbehorende toelichting.

- Omeirkel het door u gekozen antwoord --

\section{Vragen over de begeleidende brief met instrukties:}

1. Is de gekozen aanhef ('Geachte mevrouw, mifnheer') naar uw mening te formeel?

1. Nee

2. Ja, beter is $\ldots \ldots \ldots$.

2. Zijn de doelstellingen van het onderzoek $u$, na lezing van de begeleidende brief, geheel duidelijk?

1. Ja, geheel

2. Ja, enigszins

3. Nee, niet helemaal

4. Nee, volstrekt niet

2.1. Indien NEE: wat is niet duidelijk?

3. Bent $u$ van mening dat de genoemde doelstelilingen een jaarlijkse enquête rechtvaardigen?

1. Nee, zeer zeker niet

2. Nee, niet echt

3. Ja, enigszins

4. Ja, zeer zeker wel

4.1. Zijn de instrukties duidelijk genoeg?

1. Ja

2. Nee

Indien MEE: - Welke niet? 
4.2. Zijn er instrukties die ontbreken?

1. Nee

2. Ja, namelifk.

4.3. Zijn er instrukties die achterwege gelaten kunnen worden?

1. Nee

2. Ja, namelijk.

II. Vragen over de jaarkaart en de daarbijbehorende toelichting:

5. Hoelang bent u bezig geweest met het invullen van de concept-jaarkaart?

$$
\text { ca. ..... minuten }
$$

6. Is de lay-out van de jaarkaart en de bijbehorende toelichting overzichtelijk genoeg?

1. Ja, zeer overzichtelijk

2. Ja, overzichtelijk genoeg

3. Nee, moet beter

4. Nee, zeer onoverzichtelijk

6.2. Indien $\mathrm{NEE}$ : heeft $\mathrm{u}$ suggesties voor verbetering?

7. Bent u van mening dat de volgorde van de vragen onlogisch is?

1. Nee

2. Ja, omdat.

8. Zijn er vragen die naar uw mening, in het licht van de genoende onderzoeksdoelstellingen, overbodig zijn?

1. Nee

2. Ja, namelijk.

9. Zijn er items in de jaarkaart opgenomen die naar uw mening zodanig privacygevoelig zijn, dat u weigert om vragen daarover te beantwoorden?

1. Nee

2. Ja, namelijk

10. Bent $u$ bij het doornemen van de jaarkaart en toebehoren, onbekende begrippen tegengekomen of begrippen die voor tweeërlei uitleg vatbaar zijn?

1. Nee, geen van beide

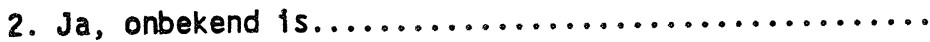

3. Ja, voor tweeërlei uitleg vatbaar is.............. 
11. Bevat de jaarkaart vragen waarop het antwoord niet of moeilijk te geven is? (Bijvoorbeeld ondat de vraag onduidelijk is of omdat het moeilijk is om een exact antwoord te geven)

1. Nee

2. Ja, namelijk.

12. Zijn er bij de gesloten vragen antwoordmogelijkheden die ontbreken?

1. Nee

2. Ja, namelijk bij vraag..........

13. Zijn er bij de gesloten vragen overlappende antwoordmogelijkheden?

1. Nee

2. Ja, namelijk bij

14. Zou $u$ het bezwaarlijk vinden als ook uw 'werkadres' wordt opgenomen in het adressenbestand van afgestudeerden?

1. Nee

2. Ja, omdat

TOT SLOT:

Het is goed mogelijk dat er in dit evaluatie-formulier éen of meerdere facetten van de concept-jaarkaart niet aan de orde zijn gekomen waar u kritiek op heeft of wellicht suggesties ter verbetering. Zou u die dan hieronder willen vermelden?

Hartelijk dank voor de tijd die $u$ heeft vrijgemaakt om dit evaluatieformulier in te vullen. Wilt u zowel de ingevulde jaarkaart als dit evaluatleformulier naar ons terug sturen? Wij zullen u zo snel mogelijk uw boekenbon toesturen.

Met vriendelijke groeten,

Researchcentrum voor Onderwijs en Arbeidsmarkt,

drs. J.W. van Dam

\section{Inlichtingen:}

Rijksuniversiteit Limburg

FdEW/ROA

tav. J. van Dam

Postbus 616

6200 MD MAASTRICHT

tel. 043-888315 
Facultatieve items in de first-destinations survey in Groot-Brittannië

- Nationality;

- Country of origin (naturalised);

- County within UK;

- College/ Institute (if applicable);

- Date of award/gradution/completion/leaving;

- Sponsorship only covered under employment;

- Definition of sponsorship (may need further discussion);

- Principal source of finance;

- Professional qualifications aimed at while in employment;

- Salary (including allowances);

- Status of respondent (full-time or not);

- Age;

- Identification number;

- Teacher training details;

- Name of employing school;

- Details of voluntary service, particularly overseas;

- Contact with employers (how first made);

- General survey of CAS activities;

- Offer of help and request for vacancy lists;

- Mutual aid (other services). 

